\title{
Analysis of aging effects and effectiveness of dewatering treatment methods on acid mine drainage sludge
}

Phanindra Kumar V. Kunderu

West Virginia University

Follow this and additional works at: https://researchrepository.wvu.edu/etd

\section{Recommended Citation}

Kunderu, Phanindra Kumar V., "Analysis of aging effects and effectiveness of dewatering treatment methods on acid mine drainage sludge" (2005). Graduate Theses, Dissertations, and Problem Reports. 4165.

https://researchrepository.wvu.edu/etd/4165

This Thesis is protected by copyright and/or related rights. It has been brought to you by the The Research Repository @ WVU with permission from the rights-holder(s). You are free to use this Thesis in any way that is permitted by the copyright and related rights legislation that applies to your use. For other uses you must obtain permission from the rights-holder(s) directly, unless additional rights are indicated by a Creative Commons license in the record and/ or on the work itself. This Thesis has been accepted for inclusion in WVU Graduate Theses, Dissertations, and Problem Reports collection by an authorized administrator of The Research Repository @ WVU. For more information, please contact researchrepository@mail.wvu.edu. 
Analysis of Aging Effects and Effectiveness of Dewatering Treatment Methods on Acid Mine Drainage Sludge

Phanindra Kumar V. Kunderu

Thesis submitted to the College of Engineering and Mineral Resources

at West Virginia University in partial fulfillment of the requirements for degree of

\author{
Master of Science \\ In \\ Civil and Environmental Engineering \\ Roger C. Viadero, Jr., Ph.D., Chair \\ Donald D. Gray, Ph.D., P.E. \\ Lian-Shin Lin, Ph.D., P.E. \\ Department of Civil and Environmental Engineering
}

Morgantown, West Virginia

2005

Keywords: Acid Mine Drainage Sludge, Aging Effects, Mixing, Dewatering Methods 


\begin{abstract}
Analysis of Aging Effects and Effectiveness of Dewatering Treatment Methods on Acid Mine Drainage Sludge
\end{abstract}

Phanindra Kumar V. Kunderu

Acid Mine Drainage (AMD) is produced when sulfide minerals in overburden are subjected to oxygen and water, and generally contains low $\mathrm{pH}$, high acidity and high dissolved metal concentrations. Typically, active treatment of AMD involves the addition of a neutralizing reagent to raise the $\mathrm{pH}$ and precipitate the metals as their respective insoluble metal hydroxides. As a by-product of the active treatment of AMD, a large amount of sludge is generated. A site, established in Monongalia County, WV for the active treatment of AMD using ammonia and hydrogen peroxide, generated sludge consisting mainly of water with a total solids concentration in the range of $\sim 0.15-1.20 \%$ $(\mathrm{g} / \mathrm{g})$. No data on the sludge from anhydrous ammonia treated AMD was available in the literature. The objectives of this research were (1) determine if aging, storage temperature $\left(4^{\circ} \mathrm{C}\right.$ and $\left.20^{\circ} \mathrm{C}\right)$ and mixing affect the properties of sludge collected after primary settling and the dewatering of AMD sludge which would further affect our approach to treatability and (2) to study the effectiveness of dewatering treatment methods on the sludge collected before and after primary settling.

The properties considered for the aging experiment were $\mathrm{pH}$, specific conductance, percent settled sludge, viscosity, specific resistance to filtration (SRF) and particle size distribution. All the properties were analyzed in triplicate except $\mathrm{pH}$ and specific conductance. Three dewatering methods were considered: vacuum filtration, pressure filtration and flocculant addition and were evaluated based on filtrate volume, percent total solids, efficiency and concentration factor.

Although the sludge properties were affected by storage temperature, time and mixing, changes were so small as to not have any practical application. It was concluded that the sludge can be stored at temperatures ranging from 4 to $20^{\circ} \mathrm{C}$. The most effective dewatering method for the sludge collected before primary settling was vacuum filtration, while the most effective dewatering method for the sludge collected after primary settling was pressure filtration based on filtrate volume, percent total solids, efficiency and concentration factor. Process economics for each dewatering method were evaluated to determine the best dewatering method at the site. Vacuum filtration was found to have greater total annual costs than pressure filtration. From an economic point of view, using pressure filtration to dewater the sludge collected after primary settling is recommended. However, to avoid the problems associated with pumping (freezing of pipes in winter) the sludge to the drying pond, using vacuum filtration to dewater the sludge collected before primary settling would be more advantageous. 


\section{ACKNOWLEDGEMENTS}

The author would like to sincerely thank his advisor, Dr. Roger C. Viadero, Jr., for his support and able guidance in the completion of this thesis. The author would also like to thank Dr. Donald D. Gray and Dr. Lian-Shin Lin, the other committee members for providing valuable suggestions and corrections in improving this thesis.

The author would also like to thank Dr. Karen Buzby for her guidance and assistance with sample collection and lab analysis. The author wishes to thank Ms. Aislinn Tierney, Mr. Xinchao Wei, Mr. James Cunningham, and Mr. William Ravenscroft for their help.

The project was provided by the Division of Mining and Reclamation (DMR) of the West Virginia Department of Environmental Protection (WVDEP), to whom the author is grateful.

Finally, the author would like to thank his mom, Mrs. Prabhavathi Kunderu and his brother, Mr. Kiran Kunderu for their love and continuous encouragement. 


\section{TABLE OF CONTENTS}

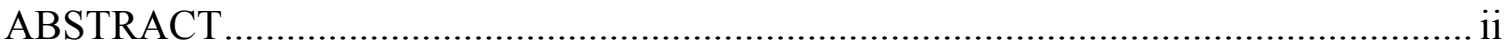

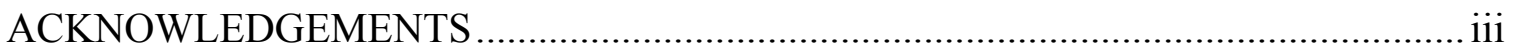

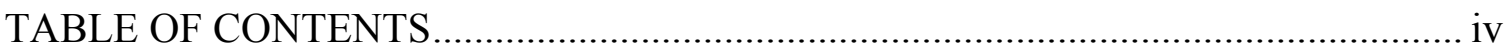

LIST OF TABLES

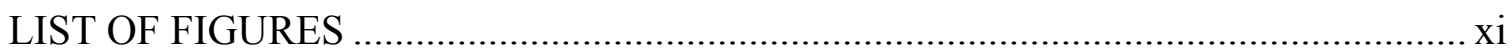

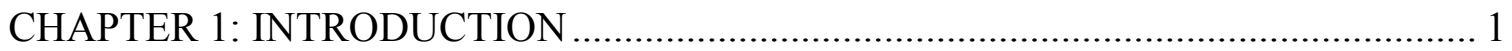

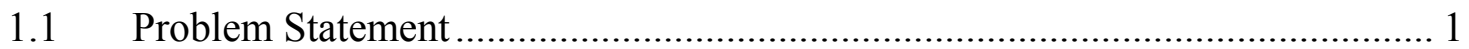

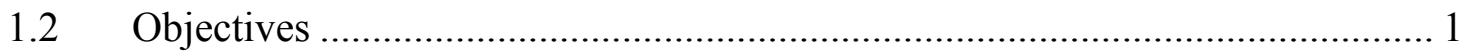

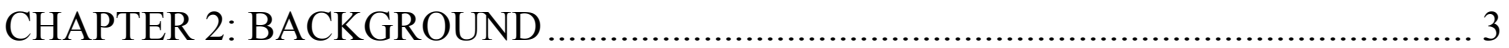

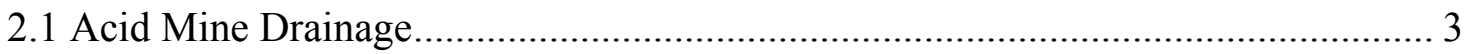

2.2 Prevention and Control of Acid Mine Drainage .................................................... 9

2.2.1 Control of Acid Mine Drainage …….......................................................... 9

2.2.1.1 Alkaline Amendments to Mines ............................................................. 9

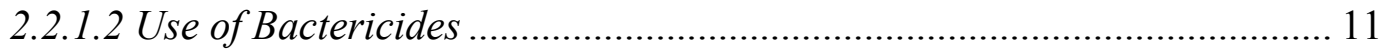

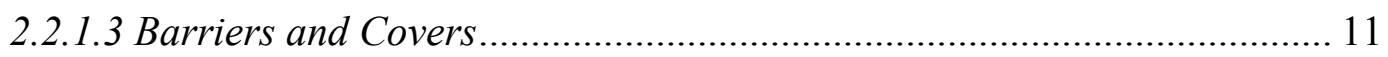

2.2.1.4 Remining of Abandoned Mines ........................................................... 13

2.3 Treatment of Acid Mine Drainage ..................................................................... 14

2.3.1 Passive Treatment of Acid Mine Drainage .................................................... 14

2.3.1.1 Wetlands (Aerobic and Anaerobic)......................................................... 14

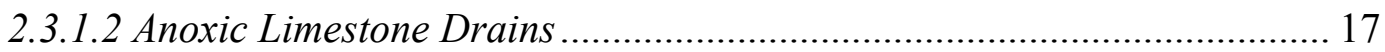


2.3.1.3 Open Limestone Channels ................................................................... 18

2.3.2 Active Treatment of Acid Mine Drainage ..................................................... 19

2.3.2.1 Chemicals for the Treatment of AMD .................................................. 19

2.3.2.2 Limestone (Calcium Carbonate) ................................................................. 21

2.3.2.3 Hydrated Lime (Calcium Hydroxide) ................................................... 22

2.3.2.4 Soda Ash (Sodium Carbonate) ………………..................................... 22

2.3.2.5 Caustic Soda (Sodium Hydroxide) .......................................................... 23

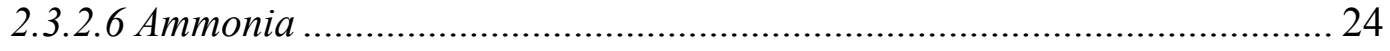

2.3.2.7 Special Chemicals for the Treatment of AMD ......................................... 25

2.3.2.8 Costs for the Chemical Treatment of AMD.............................................. 26

2.3.2.9 Floc Generation by Chemical Treatment of AMD................................... 27

2.3.2.10 Disposal of Acid Mine Drainage Sludge .............................................. 29

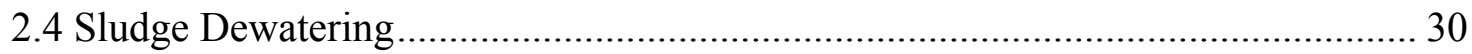

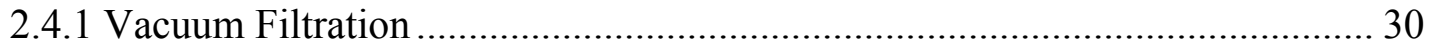

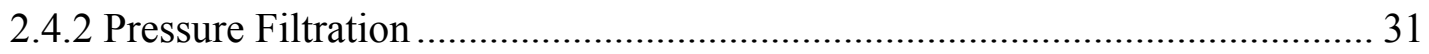

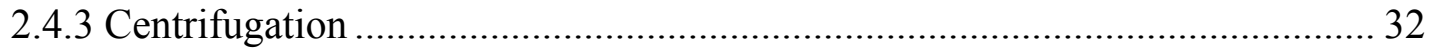

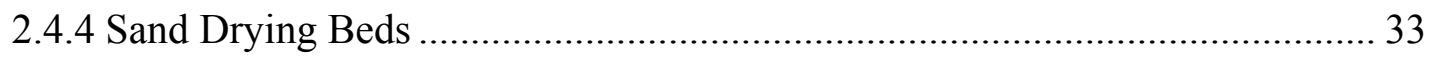

2.4.5 Coagulants and Flocculants ......................................................................... 34

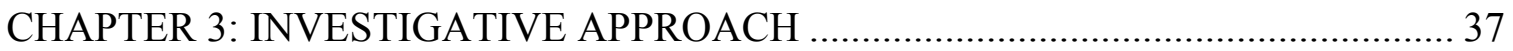

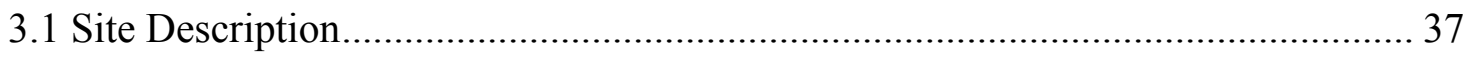

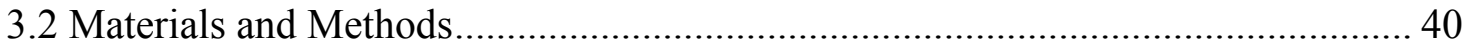

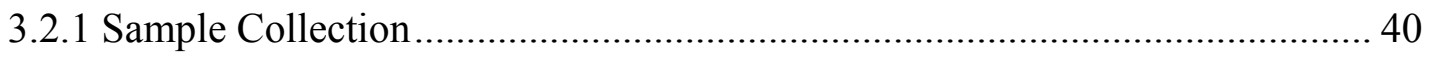


3.2.2 Sludge Characterization Methods ................................................................... 41

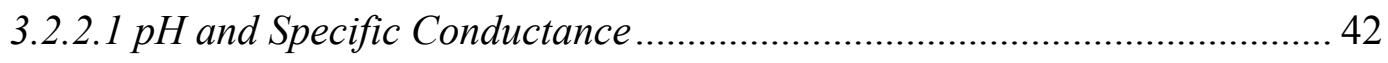

3.2.2.2 Percent Settled Sludge …………………........................................... 42

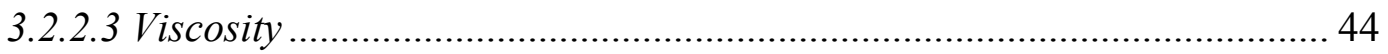

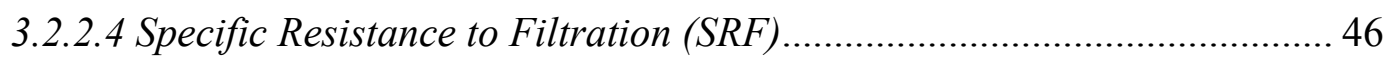

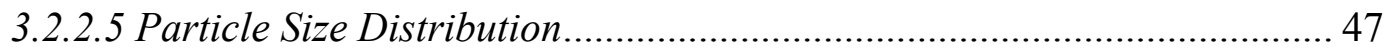

3.2.2.6 Total Solids and Total Suspended Solids ................................................ 48

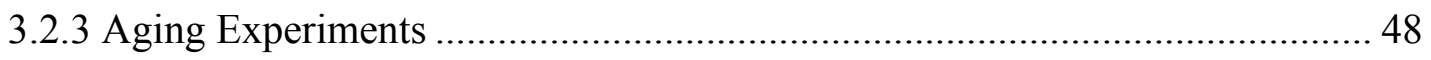

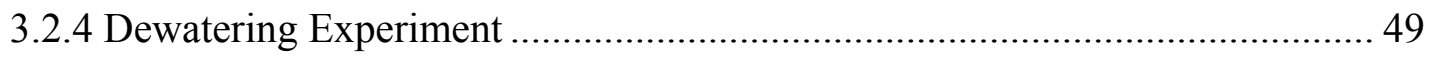

3.2.4.1 Vacuum Filtration after Flocculant Addition ........................................... 52

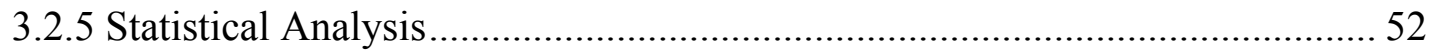

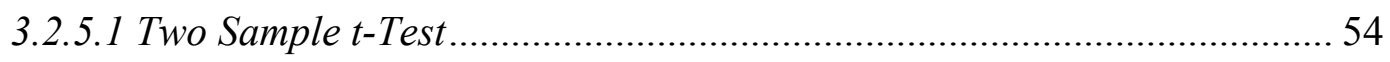

3.2.5.2 Mann-Whitney Rank Sum Test ............................................................. 56

3.2.5.3 Analysis of Variance (ANOVA) ................................................................ 57

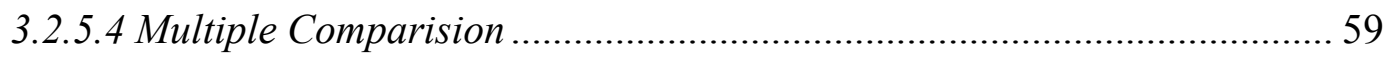

3.2.5.5 Non-parametric Kruskal-Wallis Test ....................................................... 60

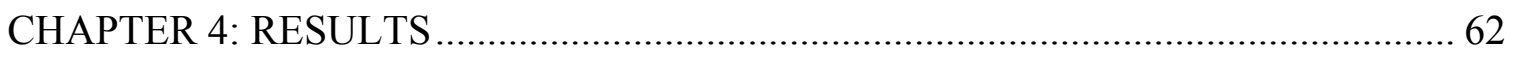

4.1 Chemical Analysis of Sludge from the Treatment Site .......................................... 62

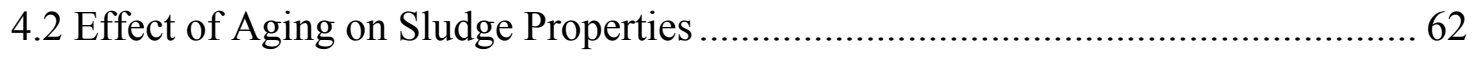

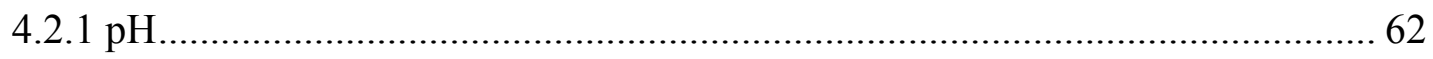

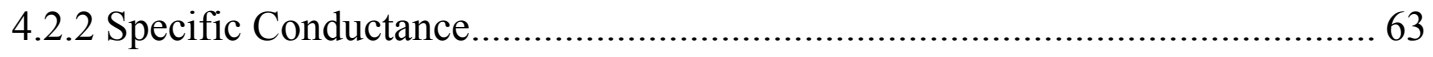

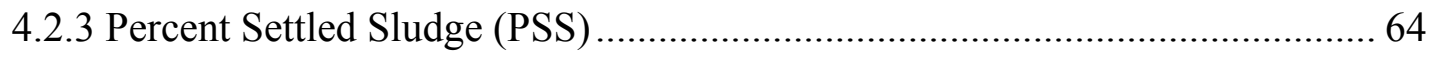

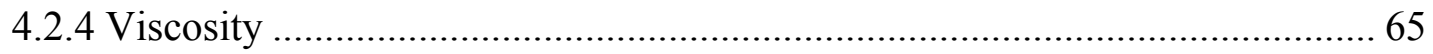




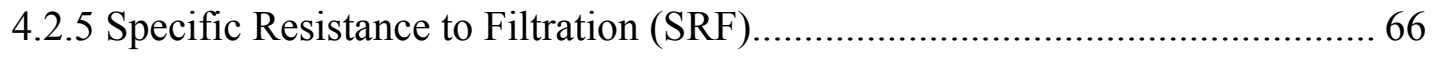

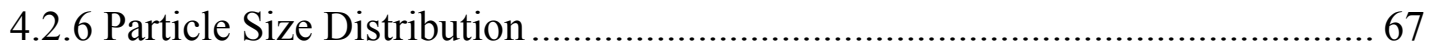

4.3 Effect of Dewatering Treatment Methods ............................................................. 69

4.3.1 Comparision of Sludge Characteristics............................................................ 69

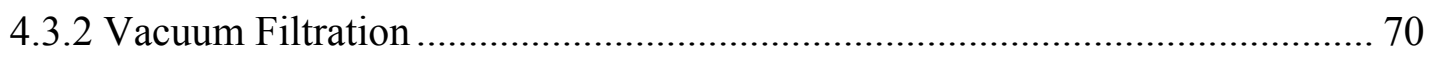

4.3.2.1 Sludge Collected Before Primary Settling ............................................... 70

4.3.2.2 Sludge Collected After Primary Settling .................................................. 73

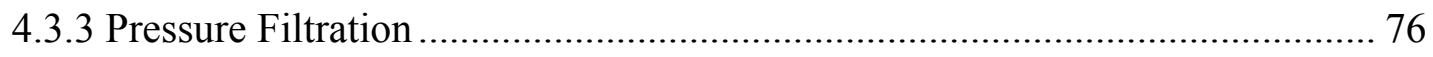

4.3.3.1 Sludge Collected Before Primary Settling ............................................. 76

4.3.3.2 Sludge Collected After Primary Settling .................................................. 76

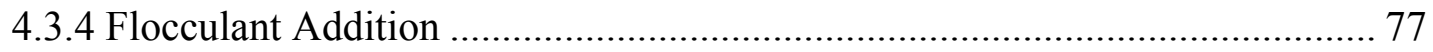

4.3.4.1 Sludge Collected Before Primary Settling .............................................. 77

4.3.4.2 Sludge Collected After Primary Settling ................................................ 82

4.3.5 Vacuum Filtration After Flocculant Addition................................................ 85

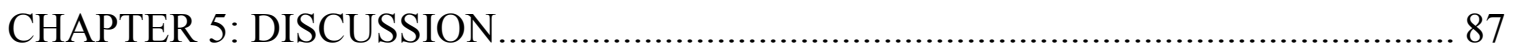

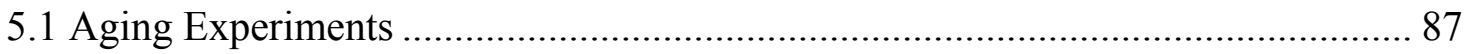

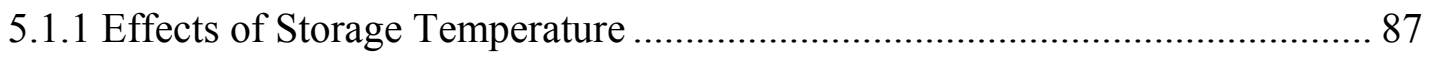

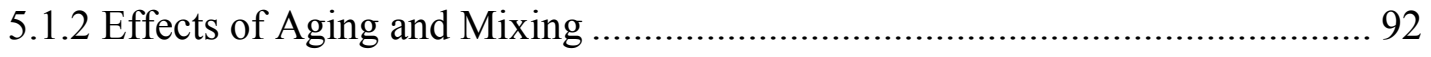

5.2 Effect of Dewatering Treatment Methods .............................................................. 93

5.2.1 Recommended Dewatering Method for Sludge Collected Before Primary

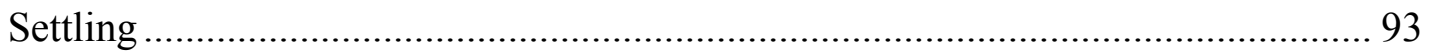


5.2.2 Recommended Dewatering Method for Sludge Collected After Primary Settling 95

5.2.3 Recommended Dewatering Method at the Treatment Site ………….............. 96

5.2.3.1 Pros and Cons of Using Vacuum Filtration at the Treatment Site...... 97

5.2.3.2 Pros and Cons of Using Pressure Filtration at the Treatment Site

5.2.4 Economics of Vacuum and Pressure Filtration at the Treatment Site 98

5.2.5 Beneficial Uses of the Concentrated Sludge from the Treatment Site 100 CHAPTER 6: SUMMARY AND CONCLUSIONS 104

6.1 Novelty of the Work 104

6.2 Purpose of the Study. 104

6.3 Effect of Aging, Temperature and Mixing on Sludge Properties 104

6.4 Effect of Dewatering Treatment Methods 105

CHAPTER 7: REFERENCES 108

APPENDIX A: DATA FROM THE AGING EXPERIMENT 114 APPENDIX B: DATA FROM DEWATERING EXPERIMENTS 118 APPENDIX C: DATA FROM KRUSKAL-WALLIS TEST IN THE AGING EXPERIMENT 124

APPENDIX D: FLOCCULANT ADDITION PROCEDURE. 127 


\section{LIST OF TABLES}

Table

Page

Table 2.1: Coal production (tons) in the United States and West Virginia 5

Table 2.2: Limits on underground mine effluent based on 40 CFR 434 Subparts B and C under the Code of Federal Regulations.....

Table 2.3: Chemicals for the AMD treatment ....................................................... 20

Table 2.4: Costs for the AMD treatment at the site using 4 different reagents ............... 27

Table 3.1: Raw water data from the site (Jan 1996 - Feb 2003) .................................. 37

Table 3.2: Instruments and methods used for characterization of sludge samples.......... 42

Table 3.3: Statistical methods used in the aging experiment....................................... 53

Table 3.4: Statistical methods used in the dewatering experiment. ............................... 54

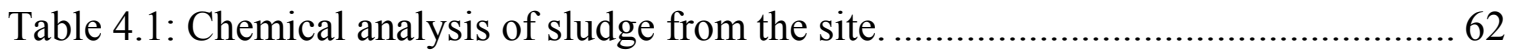

Table 4.2: Properties of the sludge collected before and after primary settling.............. 70

Table 4.3: Summary of dewatering methods applied on sludge collected before primary settling. Initial \% solids were $0.19 \pm 0.03 \mathrm{~g} / \mathrm{g}$.

Table 4.4: Summary of dewatering methods applied on sludge collected after primary settling. Initial \% solids were $0.84 \pm 0.30 \mathrm{~g} / \mathrm{g}$.

Table 4.5: Analysis of variance results for flocculants added to the sludge samples collected before primary settling.

Table 4.6: Results from the analysis of variance test for flocculants added to the sludge samples collected after primary settling. 83

Table 5.1: Hydroxide species of $\mathrm{Fe}^{3+}$ and $\mathrm{Al}^{3+}$ 87

Table 5.1: Parameters for the effective dewatering methods applied on sludge samples collected before and after primary settling. 94

Table 5.2: Typical solids in cake obtained by using vacuum filtration. 94 
Table 5.3: Typical solids in the cake obtained by using pressure filtration.

Table 5.4: Typical costs associated with vacuum and pressure filtration at the treatment

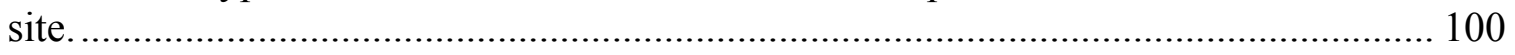




\section{LIST OF FIGURES}

Figure

Page

Figure 2.1: Streams with fisheries impacted by AMD in MD, OH, PA, VA and WV ...... 4

Figure 2.2: A stream contaminated with acid mine drainage. ...................................... 8

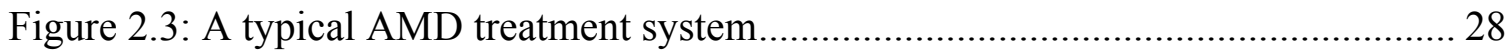

Figure 2.4: A typical vacuum filtration apparatus ................................................ 31

Figure 2.5: A typical belt filter apparatus .............................................................. 32

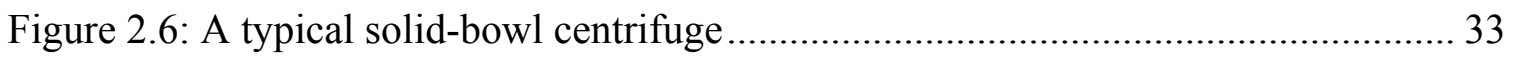

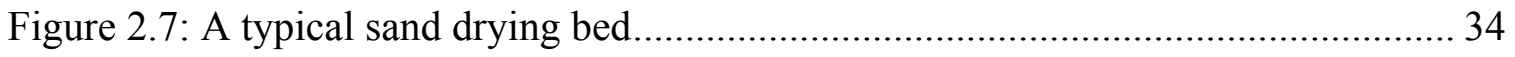

Figure 3.1: Site map of the AMD treatment at the site ............................................ 38

Figure 3.2: Addition of $\mathrm{H}_{2} \mathrm{O}_{2}$ and $\mathrm{NH}_{3}$ to the acid mine water at the site..................... 39

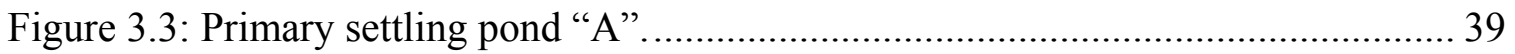

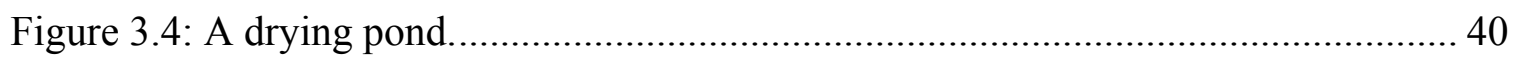

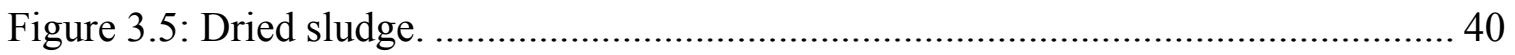

Figure 3.6: Schematic of the two sample collection points at the site.......................... 41

Figure 3.7: Variation in percent settled sludge with time....................................... 43

Figure 3.8: Measurement of percent settled sludge (a) Initial and (b) after 24 hrs.......... 43

Figure 3.9: A sample plot for determination of viscosity....................................... 46

Figure 3.10: Coulter LS Series Particle Size Analyzer............................................... 48

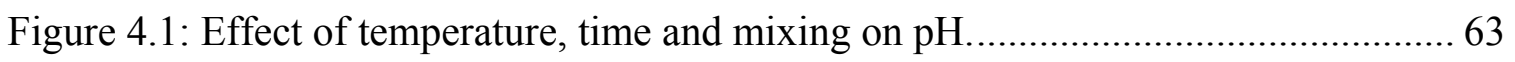

Figure 4.2: Effect of temperature, time and mixing on specific conductance................. 64

Figure 4.3: Effect of temperature, time and mixing on percent settled sludge............... 65

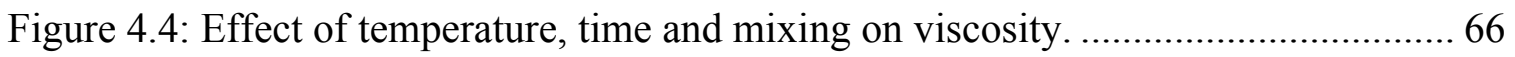


Figure 4.5: Effect of temperature, time and mixing on SRF.

Figure 4.6: Effect of temperature, time and mixing on mean particle size...................... 68

Figure 4.7: Effect of temperature, time and mixing on mode of particle size.

Figure 4.8: Efficiency of vacuum filtration applied on sludge collected before primary settling.

Figure 4.9: Concentration factor for vacuum filtration applied on sludge collected before primary settling.

Figure 4.10: Efficiency of vacuum filtration and pressure filtration applied on sludge collected after primary settling.

Figure 4.11: Concentration factor for vacuum filtration and pressure filtration applied on sludge collected after primary settling. 75

Figure 4.12: Dewatering time by vacuum filtration and pressure filtration applied on sludge collected after primary settling.

Figure 4.13: Effect of flocculant concentration on $\%$ total solids for sludge collected before primary settling.

Figure 4.14: Effect of flocculant concentration on clarified volume for sludge collected before primary settling.

Figure 4.15: Effect of flocculant concentration on \% settled sludge for sludge collected before primary settling.

Figure 4.16: Effect of flocculant concentration on efficiency for sludge collected before primary settling.

Figure 4.17: Effect of flocculant concentration on concentration factor for sludge collected before primary settling.

Figure 4.18: Effect of flocculant concentration on \% settled sludge for sludge collected after primary settling.

Figure 4.19: Effect of flocculant concentration on clarified volume for sludge collected after primary settling.

Figure 4.20: Effect of flocculant concentration on efficiency for sludge collected after primary settling. 
Figure 4.21: Effect of flocculant concentration on \% total solids for sludge collected after

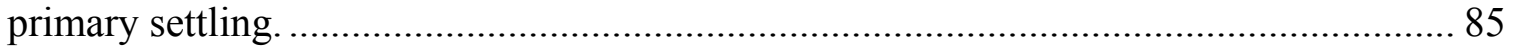

Figure 4.22: Effect of flocculant concentration on concentration factor for sludge

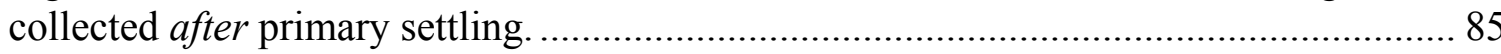

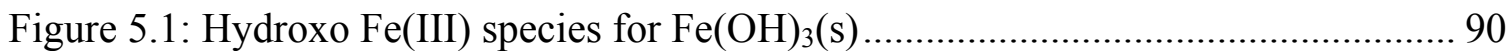

Figure 5.2: Hydroxo $\mathrm{Al}(\mathrm{III})$ species for freshly precipitated $\mathrm{Al}(\mathrm{OH})_{3}(\mathrm{~s}) \ldots \ldots \ldots \ldots \ldots \ldots \ldots . . . . . . . . . . . .91$

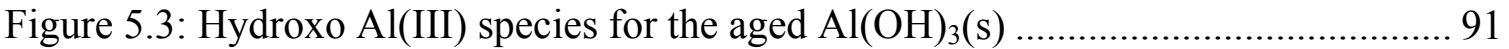




\section{CHAPTER 1: INTRODUCTION}

\subsection{Problem Statement}

Acid mine drainage (AMD) is produced when sulfide minerals in overburden are exposed to oxygen and water. AMD generally contains low $\mathrm{pH}$, high acidity and high dissolved metal concentrations. A site was established in Monongalia County, West Virginia for the active treatment of AMD from underground abandoned mines using hydrogen peroxide and ammonia to facilitate oxidation of ferrous iron, increase $\mathrm{pH}$ and subsequently precipitate metals. A large amount of sludge is produced as a by-product at the treatment site. The sludge consists mainly of water with percent total solids in the range of $\sim 0.15-1.20 \%(\mathrm{~g} / \mathrm{g})$. Sludge disposal is the main problem associated with the site. In order to enhance operational efficiency and reduce disposal costs, research is being conducted to improve the current dewatering techniques to reduce the sludge volume to be disposed off.

\subsection{Objectives}

The objectives of this research were to (1) determine if aging, storage temperature $\left(4^{\circ} \mathrm{C}\right.$ and $\left.20^{\circ} \mathrm{C}\right)$ and mixing affect the properties of sludge collected after primary settling and the dewatering of AMD sludge which would further affect our approach to treatability and (2) study the effectiveness of dewatering treatment methods on the sludge collected before and after primary settling.

The properties of the sludge considered for the aging effects were $\mathrm{pH}$, specific conductance, percent settled sludge, viscosity, specific resistance to filtration (SRF) and particle size distribution. For the dewatering experiment, the same properties were 
considered except particle size distribution and the dewatering methods considered were vacuum filtration, pressure filtration and flocculant addition. 


\section{CHAPTER 2: BACKGROUND}

\subsection{Acid Mine Drainage}

Acid mine drainage is one of the major environmental problems experienced by the mining industry. The mining industry contributes significantly to the economy of many regions in Northern America (Aubertin and Bussiere 2001). Acid mine drainage (AMD) is produced when the sulfide minerals in the rocks are exposed to oxygen $\left(\mathrm{O}_{2}\right)$ and water $\left(\mathrm{H}_{2} \mathrm{O}\right)$ (Georgopoulou et al. 1996). The major cause of acid drainage problem is mining, although there are other causes such as highway construction and deep excavation of soil (Skousen 1995). The major mineral contributing to the AMD generation is pyrite $\left(\mathrm{FeS}_{2}\right)$ (Gray 1997).

Approximately $20,000 \mathrm{~km}$ of streams and rivers in the United States are contaminated by AMD and $90 \%$ of the AMD contaminating the streams and rivers is from abandoned surface and deep mines (Ziemkiewicz et al. 2003). Approximately 230,000 acres of land was mined for coal mined in West Virginia before 1977 and only 2,136 acres of highly degraded land had been reclaimed in West Virginia from 1977 to 1991 (Skousen and Politan 1993). Figure 2.1 shows the streams impacted by AMD in Maryland, Ohio, Pennsylvania, Virginia and West Virginia.

Coal was first mined in the United States around 1750 near Richmond, VA. The mining operations started on a small scale. As the demand for coal increased, underground mines came into existence during the 1800's. By 1900, 200 million tons of coal was mined annually and by 1920, 568 million tons of coal was mined. In 1980, 823 million tons of coal was mined and in the year 1990, 1 billion tons of coal was mined 
(Skousen and Ziemkiewicz 1996). Coal production in the United States and West Virginia on a year to year basis is given in Table 2.1.

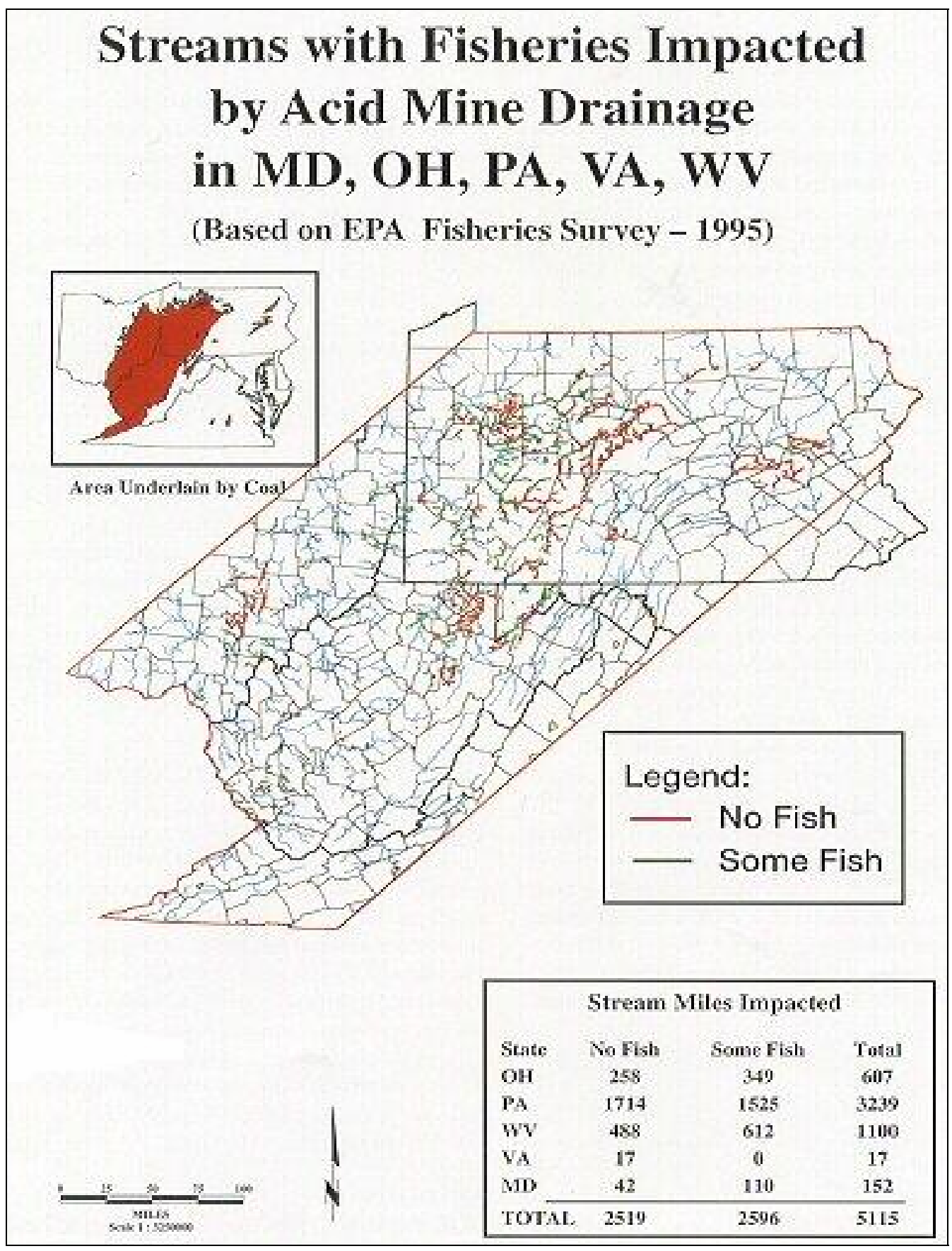

Figure 2.1: Streams with fisheries impacted by AMD in MD, OH, PA, VA and WV (Source: http://www.wvu.edu/ agexten/landrec/acidmine.htm). 
Table 2.1: Coal production (tons) in the United States and West Virginia (Source: Skousen and Ziemkiewicz 1996 and the Office of Surface Mining).

\begin{tabular}{ccc}
\hline Year & $\begin{array}{c}\text { United States } \\
\text { (million tons) }\end{array}$ & $\begin{array}{c}\text { West Virginia } \\
\text { (million tons) }\end{array}$ \\
\hline 1900 & 200 & 21 \\
1920 & 568 & 89 \\
1940 & 460 & 127 \\
1960 & 415 & 120 \\
1980 & 823 & 121 \\
1985 & 879 & 128 \\
1990 & 1,025 & 171 \\
1993 & 954 & 143 \\
1996 & 1,023 & 156 \\
1999 & 1,092 & 159 \\
2002 & 1,082 & 149 \\
\hline
\end{tabular}

The Surface Mining Control and Reclamation Act (SMCRA) was passed on August 3, 1977. SMCRA is the law that sets water quality standards for surface mining. SMCRA also defined an abandoned mine land as an abandoned land that was mined and left in an inadequate reclamation status before August 3, 1977 with no reclamation responsibility by an individual or a company under the state or federal laws. Approximately 85,000 acres of land was identified as abandoned mine land in West Virginia in 1977.

The funds for the reclamation of these abandoned mine lands are being provided by the "Abandoned Mine Land Reclamation Fund" generated by taxing every ton of coal mined by current operations. Approximately 282 abandoned mine land sites were 
reclaimed by the state and federal reclamation projects from 1977 to 1991 (Skousen and Politan 1993). The money generated by these funds is far less than the money required to reclaim all the abandoned mine lands.

The water that is discharged from the abandoned mine lands into rivers and streams is regulated by the National Pollutant Discharge Elimination System (NPDES) which was established under Section 402 of the Clean Water Act (CWA) and is administered by the U.S. Environmental Protection Agency (EPA). The NPDES program regulates the discharge of pollutants into rivers and streams and sets effluent limits. The effluent limits for AMD are given in Table 2.2.

Table 2.2: Limits on underground mine effluent based on 40 CFR 434 Subparts B and $\mathrm{C}$ under the Code of Federal Regulations.

\begin{tabular}{ccc}
\hline Pollutant Property & $\begin{array}{c}\text { Maximum } \\
\text { Concentration for } \mathbf{1} \\
\text { day (mg/l) }\end{array}$ & $\begin{array}{c}\text { Average Concentration } \\
\text { for 30 consecutive days } \\
\text { (mg/l) }\end{array}$ \\
\hline Iron, total & 7.0 & 3.5 \\
Manganese, total & 4.0 & 2.0 \\
$\begin{array}{c}\text { Total Suspended } \\
\text { Solids (TSS) }\end{array}$ & 70 & 35 \\
pH & $6.0-9.0$ & $6.0-9.0$ \\
\hline
\end{tabular}

Acid mine drainage (AMD) is formed when water comes in contact with pyrite, under oxidizing conditions. High acidity and high dissolved metals content are the general characteristics of the resulting water after contact with pyrite. AMD formation can be explained by using the following equations:

$$
\mathrm{FeS}_{2}+\frac{7}{2} \mathrm{O}_{2}+\mathrm{H}_{2} \mathrm{O} \rightarrow \mathrm{Fe}^{2+}+2 \mathrm{SO}_{4}^{2-}+2 \mathrm{H}^{+}
$$

Equation 2.1 


$$
\begin{array}{lr}
\mathrm{Fe}^{2+}+\frac{1}{4} \mathrm{O}_{2}+\mathrm{H}^{+} \rightarrow \mathrm{Fe}^{3+}+\frac{1}{2} \mathrm{H}_{2} \mathrm{O} & \text { Equation 2.2 } \\
\mathrm{Fe}^{3+}+3 \mathrm{H}_{2} \mathrm{O} \rightarrow \mathrm{Fe}(\mathrm{OH})_{3}+3 \mathrm{H}^{+} & \text {Equation 2.3 } \\
\mathrm{FeS}_{2}+14 \mathrm{Fe}^{3+}+8 \mathrm{H}_{2} \mathrm{O} \rightarrow 15 \mathrm{Fe}^{2+}+2 \mathrm{SO}_{4}^{2-}+16 \mathrm{H}^{+} & \text {Equation 2.4 }
\end{array}
$$

In equation [2.1], pyrite is oxidized to ferrous iron, sulfate and the hydrogen ions which accounts for the acidity in water. Ferrous iron is further converted into ferric iron which is represented in equation [2.2]. The oxidation of ferrous ion to ferric ion is further catalyzed in the presence of bacteria like Thiobacillus ferrooxidans, Thiobacillus thiooxidans, and Ferrobacillus ferrooxidans. Oxidation of ferrous ion by Thiobacillus thiooxidans and Ferrobacillus ferrooxidans occurs in the $\mathrm{pH}$ range of 3.5-4.5 and the oxidation of ferrous ion by Thiobacillus ferrooxidans becomes dominant at a $\mathrm{pH}$ below 3.5 (MERG 2004). It was reported by Singer and Stumm 1970 that the oxidation of ferrous ion to ferric ion was accelerated by a factor of 106 in the presence of Thiobacillus ferrooxidans (Nyavor et al. 1996, Nyavor and Egiebor 1997). Ferric iron can be hydrolyzed into ferric hydroxide or can further react with the pyrite in the presence of water, to form additional ferrous iron, sulfate and hydrogen ions (Equations [2.3] and [2.4], Skousen 1995). The presence of bacteria aids in regeneration of ferric ions consumed in the reaction with pyrite shown in Equation 2.4 (Fowler et al. 1999). In an experiment conducted both in the presence and absence of Thiobacillus ferrooxidans in solutions having the same conditions, the dissolution of pyrite was greater in the presence of bacteria (Fowler et al. 1999).

To minimize the generation of AMD, sulfide minerals should be prevented from coming in contact with $\mathrm{O}_{2}$ and $\mathrm{H}_{2} \mathrm{O}$. Generally, oxidizing conditions are limited in the 
subsurface, where pyrite is found and pyrite remains unaffected. However, due to mining and other operations, pyrite is exposed to oxidizing conditions resulting in the formation of acid mine drainage. A stream contaminated with acid mine drainage is shown in Figure 2.2.

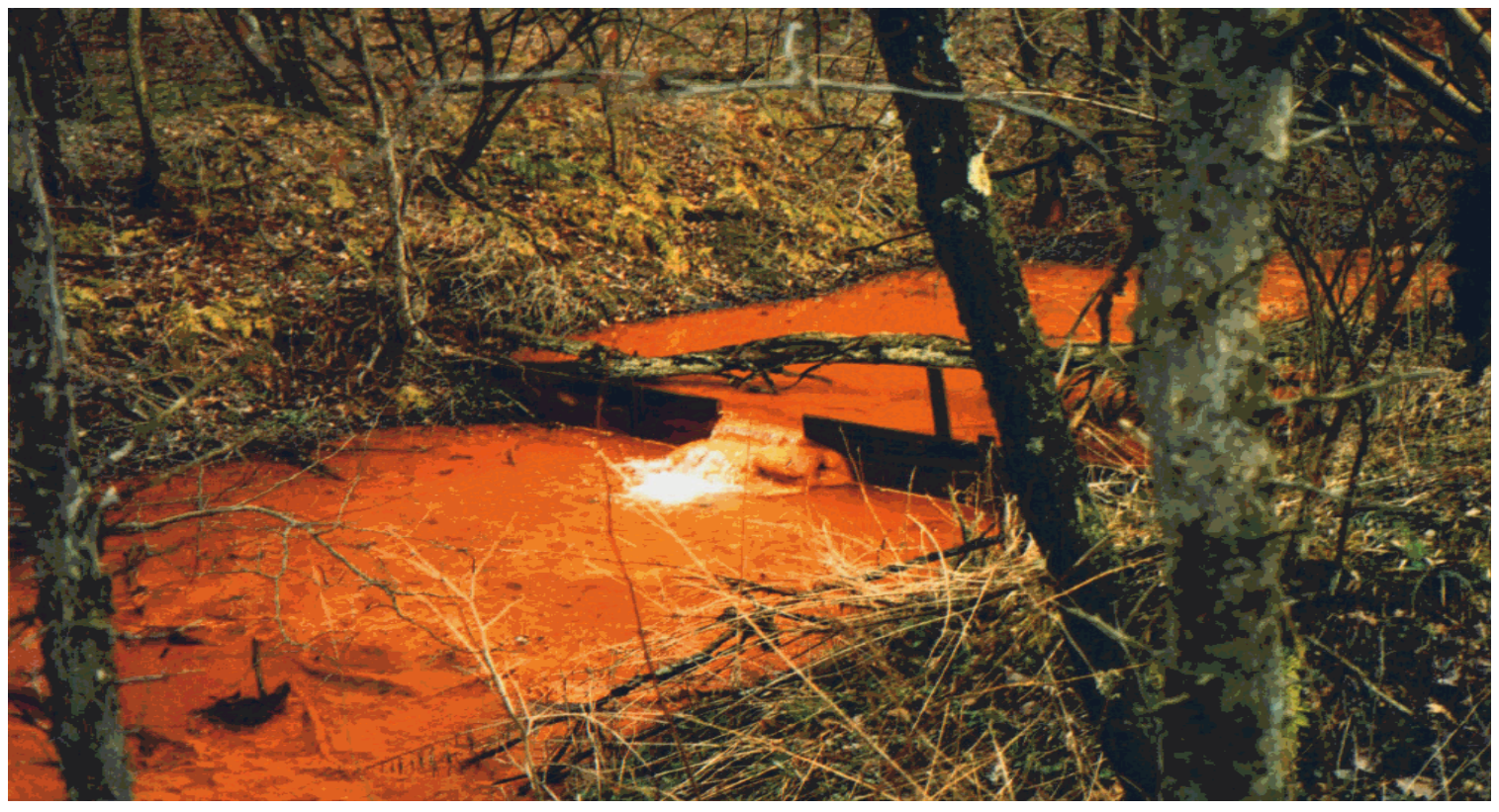

Figure 2.2: A stream contaminated with acid mine drainage.

The quality of AMD is dependent on the acidic and alkaline materials present in the geologic formations. Materials with high sulfide and low carbonate content produce an acidic drainage while alkaline-rich materials with significant sulfide concentrations produce alkaline conditions in water (Skousen 1995). AMD generally has a low $\mathrm{pH}$ and high concentrations of sulfate and iron. Acidity in AMD is due to the presence of $\mathrm{H}^{+}$ions and dissolved metals like Fe, $\mathrm{Al}$ and Mn. Acidity is the measure of amount of base needed to neutralize a certain volume of water. AMD contaminated water is toxic to fish and other aquatic organisms due to the low $\mathrm{pH}$ and armoring of substrates, which prevents aquatic organisms from living in the interstitial spaces and reduces the retention 
of organic matter. As the AMD flows in to larger streams, dilution takes place lowering the quality of the receiving stream (Skousen 1995).

\subsection{Prevention and Control of Acid Mine Drainage}

\subsubsection{Control of Acid Mine Drainage}

AMD control strategies are measures that can be taken to treat the acid-producing material directly at-source or reduce the acidity in case AMD formation has taken place or is anticipated to take place (Ziemkiewicz and Skousen 1996). Many control and preventive measures were proposed to reduce AMD generation but, were either costly, short-term solutions or difficult to apply considering the area of remediation under consideration (Fytas and Evangelou 1998).

Many of the AMD prevention techniques like alkaline amendment to active mines, use of bactericides and barriers were partially successful mainly due to the messy nature of field research and demonstration (Jeff Skousen, personal communication; Ziemkiewicz and Skousen 1996). For example, when trying to completely treat a 20-30 acre area, a small area might not be treated and a small acid seep or spot might develop from this untreated area (Jeff Skousen, personal communication). The control and preventive methods can be used for the reclamation of abandoned mines or restoration of watersheds, which may improve the health of a stream and some fish species can be reintroduced into the stream (Ziemkiewicz and Skousen 1996).

\subsubsection{Alkaline Amendments to Mines}

Research conducted on alkaline amendments indicated that alkaline amendments to active mines have the potential to successfully control AMD from acid producing 
materials (Brady et al. 1990). The alkaline materials available are limestone, fluidized bed combustion ash, kiln dust and steel making slags.

Limestone is the most readily available source of alkalinity. It is not expensive and has a neutralization potential between 75 and 100\% (Ziemkiewicz and Skousen 1996). Neutralization potential (NP) is the capacity of a base to neutralize the acidity. Limestone is safe and easy to handle, but has no cementing properties and cannot be used as a barrier. Fluidized bed combustion (FBC) ash is produced at special power generating plants that burn high sulfur coal or refuse in a FBC system. This ash contains calcium oxide with a neutralization potential between 20 and $40 \%$ and reacts quickly (Ziemkiewicz and Skousen 1996). The FBC ash hardens into cement after wetting. In research conducted by Polat et al. (2002), fly ash was successfully used to neutralize AMD formation.

Kiln dust is produced by lime and cement kilns. Kiln dust has from 10 to $20 \%$ of ash, 15 to $30 \%$ of calcium oxide and 50 to $70 \%$ of unreacted limestone as unreacted material (Ziemkiewicz and Skousen 1996). Kiln dust is pozzolan (absorbs moisture) in nature and is widely used as a stabilization and barrier material. Steel making slags which are widely available have a substantial amount of calcium oxide when fresh. The neutralization potential of these slags is between 15 to $45 \%$ (Ziemkiewicz and Skousen 1996).

Phosphate rock was also used to control AMD. Phosphate rock may react with iron present in AMD to form insoluble coatings. However, phosphate costs much more than other calcium based materials (Ziemkiewicz and Meek 1994). The sulfide minerals can be coated with iron phosphate, which prevents the oxidation of pyrite to reduce the 
formation of AMD (Fytas and Evangelou 1998). However, in a study conducted by Nyavor and Egeibor (1997), the phosphate coating was not effective in preventing the pyrite oxidation in the presence of $\mathrm{H}_{2} \mathrm{SO}_{4}$ and Thiobacillus ferrooxidans bacteria.

\subsubsection{Use of Bactericides}

Certain types of bacteria like Thiobacillus ferrooxidans, Thiobacillus thiooxidans, and Ferrobacillus ferrooxidans catalyze the conversion of ferrous ion to ferric ion present in pyritic material, previously shown in Equation 2.2. These bacteria can be controlled by using anionic surfactants, which can immediately control AMD production. These bactericides are liquids and are easy to handle and apply. These bactericides were applied to a 4.5 hectare coal reject and ash disposal area in Pennsylvania, USA in 1988. Acidity and iron concentrations reduced by $79 \%$ from $12,000 \mathrm{ppm}$ to $2,500 \mathrm{ppm}$ and $82 \%$ from $4,000 \mathrm{ppm}$ to $710 \mathrm{ppm}$, respectively. A cost saving of $\$ 300,000$ including chemical costs, sludge removal and disposal, and other operating costs was observed per year (Rastogi 1994). The disadvantage with the bactericides is that they either leach out or decompose.

\subsubsection{Barriers and Covers}

Barriers are materials that can prevent water and oxygen from entering into areas containing acid-producing materials. Barriers can control water flow but cannot completely control AMD. The different types of barriers used are the grout barriers, synthetic barriers and soil barriers.

Grout barriers are non-permeable barriers that prevent the acid-producing material from entering the groundwater, rivers and streams. Grouting is the process of filling the 
voids and cracks with materials like mortar, ash and cement. Mixtures of class F fly ash and $3-5 \%$ Portland cement are used as non-permeable materials in residential areas. Synthetic barriers are only used to isolate small pods of acid-producing materials as they are expensive.

Soil barriers are generally designed to exclude oxygen and water from acidproducing material. A soil cover used at the Waite Amulet Mine near Rouyn-Noranda, Quebec prevented $96 \%$ of precipitation into the acid producing materials, reduced oxygen concentrations by $99.9 \%$ and resulted in a $95 \%$ reduction in AMD generation over a period of three years (Yanful et al. 1994).

Permeable reactive barriers can be installed into the aquifers to control the AMD contamination (Benner et al. 1997). Permeable reactive barriers are installed by intercepting a contaminated groundwater plume with materials having the properties that promote the precipitation or degradation of the contaminant (Blowes et al. 1998). The material used in a permeable reactive barrier is generally municipal compost, leaf compost and wood chips (Blowes et al. 1998 and Gibert et al. 2003). The organic matter promotes the biological reduction of sulfates to sulfides, accompanied with the formation of metal sulfides, as shown in equations 2.5 and 2.6 (Blowes et al. 1998).

$$
\begin{array}{lr}
2 \mathrm{CH}_{2} \mathrm{O}+\mathrm{SO}_{4}{ }^{2-}+2 \mathrm{H}^{+} \rightarrow \mathrm{H}_{2} \mathrm{~S}+2 \mathrm{CO}_{2}+2 \mathrm{H}_{2} \mathrm{O} & \text { Equation 2.5 } \\
\mathrm{Me}^{2+}+\mathrm{H}_{2} \mathrm{~S} \rightarrow \mathrm{MeS}+2 \mathrm{H}^{+} & \text {Equation 2.6 }
\end{array}
$$

where, $\mathrm{CH}_{2} \mathrm{O}$ represents the organic material and Me the metals.

A permeable reactive barrier was installed into an AMD contaminated aquifer in August 1995 at the Nickel Rim mine site near Sudbury, Ontario (Benner et al. 1997). The reactive mixture in the permeable reactive barrier contained organic matter to promote 
sulfate reduction by bacteria and metal sulfide precipitation. The iron concentrations decreased from $250-1300 \mathrm{mg} / \mathrm{l}$ to $1.0-40 \mathrm{mg} / \mathrm{l}$ and $\mathrm{pH}$ increased from 5.8 to 7.0. Sulfate concentrations decreased from $2400-4600 \mathrm{mg} / \mathrm{l}$ to $200-3600 \mathrm{mg} / \mathrm{l}$ and the alkalinity $\left(\mathrm{as}_{\mathrm{CaCO}}\right)$ increased from $0-50 \mathrm{mg} / 1$ to $600-2000 \mathrm{mg} / \mathrm{l}$.

Organic covers consisting of municipal sewage sludge compost and other organic materials, can been used to prevent the formation of AMD (Peppas et al. 2000). The organic matter $\left(\mathrm{C}_{6} \mathrm{H}_{12} \mathrm{O}_{6}\right)$ decomposes aerobically (equation 2.7) at the top layers of the cover using oxygen, thus depriving the underlying reactive sulfides of oxygen.

$$
\begin{array}{ll}
\mathrm{C}_{6} \mathrm{H}_{12} \mathrm{O}_{6}+6 \mathrm{O}_{2} \rightarrow 6 \mathrm{CO}_{2}+6 \mathrm{H}_{2} \mathrm{O} & \text { Equation } 2.7
\end{array}
$$

The advantage of organic covers over the other types of covers is that organic covers have low hydraulic conductivity, high cation exchange capacity, high alkalinity and low installation costs. Research was conducted to determine the effectiveness of several covers in controlling or prevention of AMD (Yanful et al. 2000). The covers used in the study were water, soil, wood bark, limestone addition and phosphate rock addition. Water was the most effective cover in controlling or preventing the AMD formation.

\subsubsection{Remining of Abandoned Mines}

Abandoned surface or underground mines are being remined for further coal removal. Remining of abandoned mines reduces the acidity by decreasing infiltration rates, covering acid-producing materials and removing the remaining coal, the source of pyrite (Ziemkiewicz and Skousen 1996). A combination of remining with alkaline addition and special handling successfully changed the water quality from acid to alkaline at specific sites. 


\subsection{Treatment of Acid Mine Drainage}

\subsubsection{Passive Treatment of Acid Mine Drainage}

Passive treatment systems treat acid mine drainage without the addition of chemical reagents. Many different passive treatment methods have been used to treat the AMD (Brenner and Busler 2003). The most commonly used passive treatment systems used are wetlands (aerobic and anaerobic), anoxic limestone drains and open limestone channels. The passive treatment systems are cost effective, require low maintenance and do not require continuous chemical additions like the active treatment of AMD (Robinson and Robb 1995). However, passive treatment may be limited to treating AMD with low flow, low metals content and requires longer retention times and large areas (Gazea et al 1996 and Robinson and Robb 1995).

\subsubsection{Wetlands (Aerobic and Anaerobic)}

Wetlands were used for many years to treat municipal wastewater and have been used in the recent years to treat AMD (Sencindiver and Skousen 1991). It was observed that the quality of AMD improved after passing through natural Sphagnum wetlands in Ohio and West Virginia (Wieder and Lang 1982). Wetlands are low-cost, lowmaintenance systems that lessen the impacts of AMD by removing the metals and sulfate from AMD (Sasaki et al 2003).

There are several mechanisms that occur in a wetland that help in the treatment of AMD. The first mechanism is the direct uptake of metals by plants like Sphagnum and Typha. High concentrations of metals were found in plant tissues growing in a wetland (Sencindiver and Bhumla 1988). The second mechanism is adsorption and ion exchange reactions with the organic and inorganic matter. Sphagnum species have the highest 
potential for adsorption of metals (Spratt and Weider 1988). The third mechanism is microbial and chemical transformations.

Wetlands are divided into two types based on the mechanisms for AMD treatment; aerobic wetlands and anaerobic wetlands. Aerobic wetlands consist of Typha and other types of vegetation planted in shallow sediments $(<30 \mathrm{~cm})$ consisting of soil, clay or mine spoil (Ziemkiewicz et al. 2003). Aerobic wetlands must provide adequate residence time for the metals in the AMD to precipitate. Plant species are planted into the wetland to add organic matter to the system and for aesthetics. The organic matter promotes the uptake of water and metals by the plant species from AMD. A typical aerobic wetland system consists of $30-91 \mathrm{~cm}$ layer of organic matter at the bottom covered by 3-8 $\mathrm{cm}$ layer of water (Faulkner et al. 1995). Aerobic wetlands oxidize and hydrolyze the metals (especially $\mathrm{Fe}^{2+}$ ) present in the AMD to their respective insoluble hydroxides, as shown in equations 2.8 and 2.9 (Gazea et al. 1996).

$$
\begin{aligned}
& 4 \mathrm{Fe}^{2+}+3 \mathrm{O}_{2}+4 \mathrm{H}^{+} \rightarrow 4 \mathrm{Fe}^{3+}+2 \mathrm{H}_{2} \mathrm{O} \\
& \mathrm{Fe}^{3+}+3 \mathrm{H}_{2} \mathrm{O} \rightarrow \mathrm{Fe}(\mathrm{OH})_{3}+3 \mathrm{H}^{+}
\end{aligned}
$$

\section{Equation 2.8}

Equation 2.9

Anaerobic wetlands consist of Typha and other types of vegetation planted in deep organic substrates $(>30 \mathrm{~cm})$ comprising soil, peat moss, spent mushroom compost, saw dust, manure and other organic mixtures (Ziemkiewicz et al. 2003). A typical anaerobic wetland has $15-30 \mathrm{~cm}$ layer of limestone at the bottom covered by $30-61 \mathrm{~cm}$ layer of organic matter and 3-8 cm layer of water at the top (Faulkner et al. 1995). The layer of limestone continuously adds alkalinity to the system. The anaerobic conditions prevent the precipitation of iron and coating of the limestone surface. In an anaerobic wetland, the sulfate reducing bacteria oxidize the organic matter to bicarbonates and 
hydrogen sulfide. The hydrogen sulfide reacts with the dissolved metals to form insoluble metal sulfides, as shown in equations 2.10, 2.11 and 2.12 (Gazea et al. 1996).

$$
\begin{array}{lr}
2 \mathrm{CH}_{2} \mathrm{O}+\mathrm{SO}_{4}{ }^{2-} \rightarrow \mathrm{HS}^{-}+2 \mathrm{HCO}_{3}^{-}+\mathrm{H}^{+} & \text {Equation 2.10 } \\
2 \mathrm{CH}_{2} \mathrm{O}+\mathrm{SO}_{4}{ }^{2-}+2 \mathrm{H}^{+} \rightarrow \mathrm{H}_{2} \mathrm{~S}+2 \mathrm{H}_{2} \mathrm{O}+2 \mathrm{CO}_{2} & \text { Equation 2.11 } \\
\mathrm{Me}^{2+}+\mathrm{H}_{2} \mathrm{~S} \rightarrow \mathrm{MS}+2 \mathrm{H}^{+} & \text {Equation 2.12 }
\end{array}
$$

where, Me represents the dissolved metals in AMD.

Weider and Lang 1982 reported that a natural wetland in northern West Virginia increased the $\mathrm{pH}$ from 3.0 to 5.5 , decreased the iron concentration from $50 \mathrm{mg} / \mathrm{l}$ to less than $2 \mathrm{mg} / 1$ and sulfate concentrations from $250 \mathrm{mg} / 1$ to $10 \mathrm{mg} / \mathrm{l}$ (Sencindiver and Skousen 1991). There are limitations for the use of natural wetlands for the treatment of AMD. The flow of water through substrates of natural wetlands is restricted. Natural wetlands may be rich in humic acids which can hinder the wetland's ability to neutralize the acidity in AMD. After neutralization of AMD, the alkaline effluent kills the natural sphagnum wetlands if the effluent has a significant concentration of metals.

Construction of wetlands on mined lands has several benefits (Skousen et. al 1992). Wetlands provide habitat for many wildlife species, improve the aesthetics of the area and are inexpensive in treating AMD. Water after passing through a wetland may still need chemical treatment. However, the amount of reagent required to treat this water is less and therefore there are lower chemical costs.

Girts and Kleinmann 1986 reported that most constructed wetlands have a 30 to $60 \mathrm{~cm}$ thick organic substrate layer which is generally composted spent mushrooms, manure or other organic materials. A layer of crushed limestone is placed below the organic layer to neutralize the acidity if the AMD has a $\mathrm{pH}$ of 3.5 or less (Sencindiver 
and Skousen 1991). The water depth in these wetland systems is 5 to $15 \mathrm{~cm}$ above the organic substrate. A failed constructed wetland in the Jones Branch watershed in Kentucky was renovated to improve the treatment efficiency of the wetland. The wetland decreased the mean iron concentrations from 787 to $39 \mathrm{mg} / 1$, increased the $\mathrm{pH}$ from 3.38 to 6.46 and reduced the acidity from 2244 to $299 \mathrm{mg} / \mathrm{l}$ as $\mathrm{CaCO}_{3}$ (Barton and Karathanasis 1999).

\subsubsection{Anoxic Limestone Drains}

Anoxic limestone drains (ALD's) are buried beds of limestone that treat the AMD by adding alkalinity (Hedin et al. 1994). The limestone raises the $\mathrm{pH}$ of the AMD and neutralizes the acidity by adding alkalinity to AMD, as shown in equations 2.13 and 2.14 (Gazea et al. 1996).

$$
\begin{array}{lr}
\mathrm{CaCO}_{3}+2 \mathrm{H}^{+} \rightarrow \mathrm{Ca}^{2+}+\mathrm{H}_{2} \mathrm{CO}_{3} & \text { Equation 2.13 } \\
\mathrm{CaCO}_{3}+\mathrm{H}_{2} \mathrm{CO}_{3} \rightarrow \mathrm{Ca}^{2+}+2 \mathrm{HCO}_{3}^{-} & \text {Equation 2.14 }
\end{array}
$$

A typical anoxic limestone drain has a 20-40 $\mathrm{mm}$. plastic liner surrounding or covering the limestone bed and 2-4 ft. soil at the top (Faulkner et al. 1995). Anoxic conditions prevent the coating of limestone with iron oxides. Anoxic limestone drains are not effective if $\mathrm{AMD}$ has $\mathrm{Fe}^{3+}$ and $\mathrm{Al}$ as the hydroxides of these metals coat the surface of ALD's (armoring) and also plug the void spaces of limestone surface reducing the limestone dissolution and neutralization potential (Ziemkiewicz et al 1997). The effluent cannot be injected into streams immediately after passing through an ALD. Sufficient area and time must be provided to oxidize and precipitate the metals.

In Appalachian states alone, approximately 50 anoxic limestone drains have been constructed as of 1991 (Skousen 1991). Anoxic limestone drains were initially 
constructed when wetlands were not successful in treating AMD. The performance of two anoxic limestone drains to treat AMD was studied (Hedin et. al 1994). The alkalinity was increased by an average of $128 \mathrm{mg} / \mathrm{L}\left(\mathrm{CaCO}_{3}\right.$ equivalent $)$ in the first $\mathrm{ALD}$ and by $248 \mathrm{mg} / \mathrm{L}$ in the second ALD. The concentrations of $\mathrm{Fe}, \mathrm{K}, \mathrm{Mg}, \mathrm{Mn}$ and $\mathrm{SO}_{4}{ }^{2-}$ remained unchanged in the first ALD. However, in the second ALD, the concentration of Fe decreased by $30 \%$ and the concentrations of $\mathrm{K}, \mathrm{Mg}, \mathrm{Mn}$ and $\mathrm{SO}_{4}{ }^{2-}$ decreased by an average of $17 \%$. Both anoxic limestone drains improved the water quality and neutralized the acidity of the AMD.

The advantage of using limestone is that it is cheap and effective in neutralizing acidity of AMD. The construction and material costs of an ALD was approximately $\$ 18,950$ in Tennessee and $\$ 11,855$ in West Virginia (Skousen 1991). Anoxic limestone drains, when combined with wetlands to treat AMD, can improve the efficiency of the wetland by adding alkalinity to the AMD.

\subsubsection{Open Limestone Channels}

Open limestone channels are open channels lined with limestone which adds alkalinity, neutralizes the acidity and raises the $\mathrm{pH}$ of AMD in a similar manner as anoxic limestone drains. They can be applied to watershed restoration and abandoned mine land restoration projects which require one time installation costs and little to no maintenance (Ziemkiewicz et al 1997).

The main problem associated with open limestone channels is the armoring of limestone with $\mathrm{Fe}$ or $\mathrm{Al}$ hydroxides, preventing further limestone from dissolving into AMD. Open limestone channels are effective in treating AMD if the channels are 
constructed on a steep slope to reduce filling of voids by metal hydroxides and thereby, reducing the armoring effect (Ziemkiewicz et al 1994).

A titration test was conducted in a laboratory to determine the efficiency of armored and unarmored limestone to neutralize hydrochloric acid $(\mathrm{HCl})$. Unarmored limestone was 2 to $45 \%$ more effective in neutralizing the $\mathrm{HCl}$ solution as compared to armored limestone (Ziemkiewicz et al 1997). In the same study, armored limestone was 90\% as effective in treating AMD as unarmored limestone. Sandstone channels were less effective in decreasing the acidity of AMD (2\%) as compared to open limestone channels (4 to $62 \%$ ), even when armored.

\subsubsection{Active Treatment of Acid Mine Drainage}

\subsubsection{Chemicals for the Treatment of AMD}

There are six reagents commonly used to treat acid mine drainage (AMD). They are calcium carbonate $\left(\mathrm{CaCO}_{3}\right)$, calcium hydroxide $\left(\mathrm{Ca}(\mathrm{OH})_{2}\right)$, calcium oxide $(\mathrm{CaO})$, sodium carbonate $\left(\mathrm{Na}_{2} \mathrm{CO}_{3}\right)$ and sodium hydroxide $(\mathrm{NaOH})$ and ammonia $\left(\mathrm{NH}_{3}\right)$. The formulae, chemical name, common name and the costs of these six chemicals are given in Table 2.3.

The selection of the chemicals for the treatment of AMD depends on technical and economical factors. The technical factors are acidity levels, flow, concentration of the metals in water, rate and degree of chemical treatment needed and the desired final quality of water. The economic factors are the price of reagents and equipment, labor and the risk involved in the treatment using a specific chemical. The length of time that the treatment system will operate is also an important factor in determining annual and total cost of the treatment system, due to large initial capital investment. Topography of the 
site is also a crucial cost factor as the design and structural costs increase with an increase in the slope of the site.

Table 2.3: Chemicals for the AMD treatment

(Source: Skousen et al. 1996).

\begin{tabular}{cccc}
\hline Common Name & Chemical Name & Formula & $\begin{array}{c}\text { Cost } \\
\text { (\$ per ton) }\end{array}$ \\
\hline Limestone & Calcium Carbonate & $\mathrm{CaCO}_{3}$ & 10 \\
Hydrated Lime & Calcium Hydroxide & $\mathrm{Ca}(\mathrm{OH})_{2}$ & 60 \\
Pebble Quicklime & Calcium Oxide & $\mathrm{CaO}$ & 80 \\
Soda Ash & Sodium Carbonate & $\mathrm{Na}_{2} \mathrm{CO}_{3}$ & 200 \\
Caustic Soda & Sodium Hydroxide & $\mathrm{NaOH}^{2}$ & 680 \\
Ammonia & Anhydrous Ammonia & $\mathrm{NH}_{3}$ & 300 \\
\hline
\end{tabular}

The calcium compounds are less expensive than sodium compounds. However, the use of calcium compounds is limited due to the low solubility of the calcium compounds. If the sulfate concentrations in the AMD are above $2000 \mathrm{mg} / \mathrm{L}$, calcium products will react with the sulfate to form anhydrite or insoluble gypsum which may clog pipes used to discharge the treated water to the receiving streams (Skousen 1988). The carbonate compounds do not raise the $\mathrm{pH}$ of water above 8.5 while the hydroxide compounds raise the $\mathrm{pH}$ of water to above 10.0 .

Alkalinity must be added to water to compensate the acidity, raise the $\mathrm{pH}$ of the water and precipitate the metals as insoluble metal hydroxides. The $\mathrm{pH}$ range to precipitate the metals is between 6 and 9 for most of the metals with the exception of ferric ion which precipitates at a $\mathrm{pH}$ of around 3.5 (Skousen et al. 1996). The selection of an AMD treatment system depends on the concentration and the types of the metals present in the water. Ferrous ion precipitates at a $\mathrm{pH}>8.5$. However, in the presence of 
oxygen, the ferrous ion is oxidized to ferric ion which precipitates at a $\mathrm{pH} \geq 3.5$. In environments where oxygen is deficient, enough alkalinity should be added to water to raise the $\mathrm{pH}$ of water to 8.5 so that the ferrous ion precipitates. In such cases, the ferrous ion can be oxidized to ferric ion by aeration and then adding the chemical to precipitate the ferric ion. Aeration can also be done after chemical addition. Aeration reduces the amount of chemical required to remove the iron from water (Skousen et al. 1996).

\subsubsection{Limestone (Calcium Carbonate)}

Limestone is the common name for calcium carbonate $\left(\mathrm{CaCO}_{3}\right)$. Calcium carbonate reacts with the acidity in AMD to form calcium sulfate, water and carbon dioxide, as shown in equation 2.15 .

$$
\mathrm{CaCO}_{3}+\mathrm{H}_{2} \mathrm{SO}_{4} \rightarrow \mathrm{CaSO}_{4}+\mathrm{H}_{2} \mathrm{O}+\mathrm{CO}_{2} \quad \text { Equation } 2.15
$$

Limestone is cheap, safe and easy to handle. Its use has been limited due to its low solubility and its tendency to develop an external coating of ferric hydroxide, called armoring, which prevents limestone from further dissolving into AMD (Skousen et al. 1990, Skousen et al. 1996). If the $\mathrm{pH}$ of the water and the concentrations of metals are low, then finely ground limestone may be added directly into the streams (Skousen et al. 1996).

Sand sized limestone was applied to two streams which were severely contaminated by AMD (Menendez et al. 2000). High flow in the stream distributed the limestone through the streams and significantly reduced the acidity levels in both the streams. The study indicated that the efficiency of the limestone to reduce the acidity in the streams is dependent on the particle size of limestone. The stream treated with a narrow range of limestone particle size was more efficient in reducing the acidity 
compared to the other stream. The use of such methods is highly cost effective as compared to other passive and active treatment systems.

\subsubsection{Hydrated Lime (Calcium Hydroxide)}

Hydrated lime is the common name of calcium hydroxide $\left(\mathrm{Ca}(\mathrm{OH})_{2}\right)$. It is the most commonly used chemical for treating AMD. Hydrated lime is a powder that is hydrophobic in nature and is difficult to mix in water. It requires extensive mechanical mixing to dissolve in water. Hydrated lime is cost effective when the AMD has large flow and high acidity and when used in a treatment plant with a mixer/aerator to dissolve and mix the hydrated lime in water (Skousen and Ziemkiewicz 1995). Hydrated lime has limited success in removing metals like manganese where a very high $\mathrm{pH}$ is required. Calcium hydroxide reacts with the acidity in AMD to form calcium sulfate and water, as shown in equation 2.16 .

$$
\mathrm{Ca}(\mathrm{OH})_{2}+\mathrm{H}_{2} \mathrm{SO}_{4} \rightarrow \mathrm{CaSO}_{4}+2 \mathrm{H}_{2} \mathrm{O} \quad \text { Equation 2.16 }
$$

\subsubsection{Soda Ash (Sodium Carbonate)}

Soda ash is the common name of sodium carbonate $\left(\mathrm{Na}_{2} \mathrm{CO}_{3}\right)$. Soda ash is used to treat AMD with low flow and low concentrations of metals and acidity (Skousen et al. 1996). Sodium carbonate reacts with the acidity in AMD to form sodium sulfate, water and carbon dioxide, as shown in equation 2.17.

$$
\mathrm{Na}_{2} \mathrm{CO}_{3}+\mathrm{H}_{2} \mathrm{SO}_{4} \rightarrow \mathrm{Na}_{2} \mathrm{SO}_{4}+\mathrm{H}_{2} \mathrm{O}+\mathrm{CO}_{2} \quad \text { Equation 2.17 }
$$

Using soda ash to treat AMD is based on convenience rather than cost of the chemical. Soda ash is available as solid briquettes and is gravity fed to water using hoppers mounted over a basket or barrel. If the basket-hopper system is used, the 
briquettes absorb moisture and expand. Expansion causes the briquettes to stick to the sides of the hopper stopping the briquettes from dropping into the AMD stream.

Another method of feeding soda ash is by using a simple box or barrel filled with briquettes and with holes that allow for the water to flow in and out. The disadvantage of the latter is that there is no control over the amount of reagent used for AMD treatment. Briquettes are easy to handle but are expensive compared to limestone and hydrated lime (Table 2.3). Many different formulations of briquette are available but the selection of pure and high quality soda ash is important. The smaller the size of briquettes, the higher is the quality of briquettes. Large sized briquettes contain hydrated lime as binders.

\subsubsection{Caustic Soda (Sodium Hydroxide)}

Caustic soda is the common name of sodium hydroxide $(\mathrm{NaOH})$. It is used in remote locations and in low flow, high acidity situations. Sodium hydroxide reacts with the acidity in AMD to form sodium sulfate and water, as shown in equation 2.18.

$$
2 \mathrm{NaOH}+\mathrm{H}_{2} \mathrm{SO}_{4} \rightarrow \mathrm{Na}_{2} \mathrm{SO}_{4}+2 \mathrm{H}_{2} \mathrm{O} \quad \text { Equation } 2.18
$$

Caustic soda is generally used when the manganese concentrations in the AMD are very high (Skousen et al. 1990). It is gravity fed by dripping the liquid caustic soda at the surface of the AMD pond because the chemical is denser than water and sinks. Caustic soda is highly soluble in water, spreads rapidly and raises the $\mathrm{pH}$ of water quickly.

The major problems associated with the use of caustic soda are its high cost and dangers in chemical handling. Liquid caustic soda can freeze during winter months. There are many solutions to prevent the chemical from freezing including burying the 
caustic soda tank, installation of a tank heater, switching from a $50 \%$ to $20 \%$ caustic solution which lowers the freezing point from $0^{\circ} \mathrm{C}$ to $-37^{\circ} \mathrm{C}$, addition of a small amount of antifreeze to the chemical solution and using solid caustic soda for the treatment of AMD (Skousen et al. 1996).

Solid caustic soda is cheaper and easier to handle than liquid caustic soda. Burying the caustic soda tank is expensive and needs to comply with the stringent EPA regulations on underground storage tanks. Heaters must be replaced on a regular basis due to the corrosive nature of caustic soda. The most economical among the above options are either to use $20 \%$ solution of caustic soda, using some antifreeze or using solid caustic soda.

Treatment of AMD with solid caustic soda has been successful. It is generally delivered in $70 \mathrm{lb}$ drums and it is possible to regulate the rate at which solid caustic dissolves by regulating the flow of water into the drum. Solid caustic can also be used to make the liquid caustic soda. Preparation of liquid caustic soda from solid caustic soda is not cost effective when liquid caustic soda can be purchased. Treatment of AMD with solid caustic soda is cost effective compared to the use of soda ash briquettes.

\subsubsection{Ammonia}

Ammonia or anhydrous ammonia, a pungent and colorless gas at room temperature, is compressed and stored as a liquid. Ammonia, in its gaseous state, is extremely soluble and highly reactive. It behaves as a strong base and can easily raise the $\mathrm{pH}$ of water to 9.2. Ammonia reacts with water to form ammonium hydroxide which again reacts with the acidity to form ammonium sulfate and water (Equations 2.19 and 2.20). 


$$
\begin{array}{lr}
\mathrm{NH}_{3}+\mathrm{H}_{2} \mathrm{O} \rightarrow \mathrm{NH}_{4} \mathrm{OH} & \text { Equation 2.19 } \\
2 \mathrm{NH}_{4} \mathrm{OH}+\mathrm{H}_{2} \mathrm{SO}_{4} \rightarrow\left(\mathrm{NH}_{4}\right)_{2} \mathrm{SO}_{4}+2 \mathrm{H}_{2} \mathrm{O} & \text { Equation 2.20 }
\end{array}
$$

In a concentrated form, ammonia has a powerful corrosive action on human tissue (Faulkner 1990). Ammonia, which is injected into bottom of AMD ponds or inlet water, as a liquid, returns to the gaseous state once in contact with water. It should be injected into bottom of AMD ponds as ammonia is lighter than water and rises to the surface.

The advantage of ammonia is its cost compared to other chemicals like caustic soda and that it will not gel, freeze or solidify at low temperature and can be used in all the seasons. The disadvantages of using ammonia to treat AMD are the hazards associated with handling ammonia and uncertainty concerning some theoretical biological reactions due to excess application of ammonia (Faulkner 1990).

\subsubsection{Special Chemicals for the Treatment of AMD}

Apart from the six chemicals that are generally used for the treatment of AMD, many other special chemicals are also available. Some of the more specialized chemicals are potassium hydroxide $(\mathrm{KOH})$, magnesium hydroxide $\left(\mathrm{Mg}(\mathrm{OH})_{2}\right)$, magna lime $(\mathrm{MgO})$, trapzene $\left(\mathrm{CaO}_{2}\right)$, kiln dust $\left(\mathrm{CaO}\right.$ and $\left.\mathrm{Ca}(\mathrm{OH})_{2}\right)$, fly ash $\left(\mathrm{CaCO}_{3}\right.$ and $\left.\mathrm{Ca}(\mathrm{OH})_{2}\right)$ (Skousen et al. 1993). Potassium hydroxide and magna lime are similar to calcium based products. Trapzene, which is a calcium peroxide material, oxidizes the water and neutralizes the acidity. Trapzene has been used to treat AMD at many sites (Lilly and Ziemkiewicz 1992). The AMD treatment with these chemicals is expensive compared to chemicals like limestone and they are generally used only if they are locally available as a byproduct in a manufacturing process (Jeff Skousen, personal communication). Using kiln dust and fly 
ash has been limited due to the impurities present in each material. These impurities generate greater amounts of metal floc.

Introduction of air into water is called aeration. Oxidation of metals takes place due to aeration or by using oxidants. Active treatment costs could be reduced if both aeration and oxidation are used in the treatment of AMD. Oxidants aid in the complete oxidation of metals to their respective hydroxides, thereby, reducing the sludge volume. Some of the oxidants are chlorine compounds (hypochlorites and chlorides), peroxides of calcium and hydrogen and potassium permanganate (Skousen et al. 1993). Hypochlorites and hydrogen peroxide have been used effectively as oxidants. Potassium permanganate is also an effective oxidant which is used if extra oxidation of AMD is required. Oxidation of metals can also be attained by using mechanical mixers or aerators. The oxidation of $\mathrm{Fe}^{2+}$ by hydrogen peroxide is shown in equations 2.21 and 2.22 .

$$
\begin{array}{ll}
2 \mathrm{Fe}^{2+}+\mathrm{H}_{2} \mathrm{O}_{2}+2 \mathrm{H}^{+} \rightarrow 2 \mathrm{Fe}^{3+}+2 \mathrm{H}_{2} \mathrm{O} & \text { Equation 2.21 } \\
\mathrm{Fe}^{3+}+3 \mathrm{OH}^{-} \rightarrow \mathrm{Fe}(\mathrm{OH})_{3} \downarrow & \text { Equation 2.22 }
\end{array}
$$

\subsubsection{Costs for the Chemical Treatment of AMD}

AMD treatment costs are becoming a large component of the total mining and reclamation costs in the eastern United States (Skousen and Ziemkiewicz 1996). The selection of a specific chemical is dependent upon AMD flow rate, acidity levels, type and concentration of metals in the $\mathrm{AMD}$, installation and maintenance costs of the treatment system. Over a five year period, ammonia systems had the lowest annual costs for low flow $(50 \mathrm{gpm}) /$ low acidity $(100 \mathrm{mg} / \mathrm{l})$ and intermediate flow $(250 \mathrm{gpm}) /$ intermediate acidity $(500 \mathrm{mg} / \mathrm{l})$ situations; and hydrated lime systems had the lowest annual costs for high flow $(1,000 \mathrm{gpm}) /$ high acidity $(2,500 \mathrm{mg} / \mathrm{l})$ situations (Skousen $e t$ 
al. 1996). The AMD active treatment costs, using 4 different reagents and based on the data from the treatment site considered in this study, generated using the AMDTreat program provided by the Office of Surface Mining (OSM 2004), are given in Table 2.4.

Table 2.4: Costs for the AMD treatment at the site using 4 different reagents (Source: AMDTreat from the Office of Surface Mining).

\begin{tabular}{ccccc}
\hline Costs & $\begin{array}{c}\text { Caustic } \\
\text { Soda }\end{array}$ & $\begin{array}{c}\text { Hydrated } \\
\text { Lime }\end{array}$ & $\begin{array}{c}\text { Anhydrous } \\
\text { Ammonia }\end{array}$ & Soda Ash \\
\hline Installation & 26,387 & 111,136 & 14,205 & 500 \\
Maintenance & 38,655 & 47,130 & 37,437 & 36,066 \\
Capital Costs & 65,042 & 158,266 & 51,642 & 36,566 \\
Reagent Costs & 189,500 & 36,153 & 122,078 & 210,913 \\
Annual Costs & 231,706 & 81,325 & 163,857 & 252,212 \\
\hline
\end{tabular}

Soda ash had the highest reagent costs followed by caustic soda. Hydrated lime treatment had the highest installation costs, maintenance and capital costs among the four reagents as it needs a lime treatment plant and a pond aerator (Table 2.4). However due to the low reagent costs and annual costs, hydrated lime systems are appropriate for long term treatment of AMD (Skousen et al. 1996).

\subsubsection{Floc Generation by Chemical Treatment of AMD}

After the addition of chemicals to raise the $\mathrm{pH}$, the acid mine drainage is sent into sedimentation ponds to allow for the precipitation of metals. The metals present in the acid mine drainage precipitate at the bottom of the settling ponds as a loose, openstructured mass of tiny grains referred to as "floc". The amount of floc generated depends on the quality and the quantity of the water to be treated (Ackman 1982). Large volumes of AMD floc are produced in West Virginia and Appalachian states by active treatment 
of acid mine drainage. The generation of the AMD sludge is continuous as the acid conditions in the water persist, even when the mining operations have ceased. The initial problem of treating the AMD has created another problem, the disposal of sludge generated during the treatment of AMD.

Once the metals precipitate as floc at the bottom of the settling ponds, the clarified water is removed and discharged into nearby streams. A typical AMD treatment system is given in Figure 2.3. The floc must be removed and hauled to disposal sites on a regular basis to maintain the continual treatment of AMD and adequate water holding capacities. The disposal sites for the floc are generally abandoned deep mines, pits on surface mines and refuse piles. The costs for the removal and hauling of floc from the settling ponds are almost equal to the costs for the chemical treatment of water (Brown et al. 1994). The adequate disposal of large volumes of floc generated by the treatment of AMD is becoming a major concern.

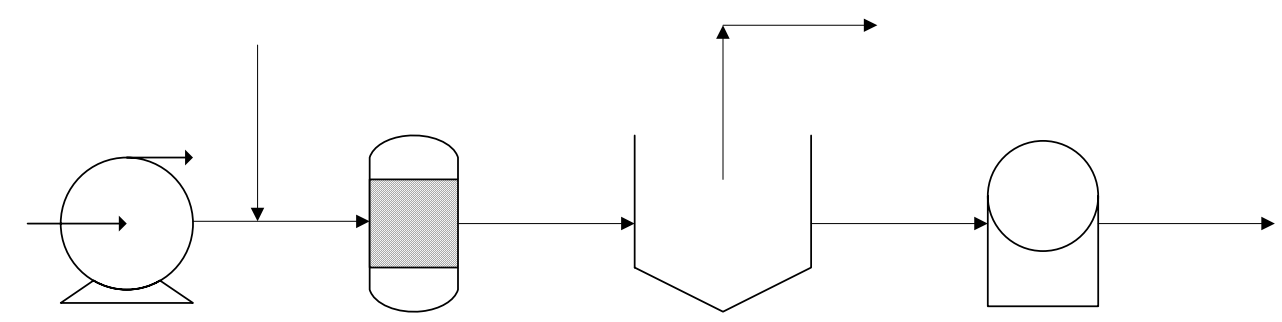

Figure 2.3: A typical AMD treatment system (Source: Ackman 1982).

The chemical composition of the acid mine drainage sludge also plays a vital role in the disposal of the sludge. The sludge consists of hydrated oxides of iron (ferrous and ferric) and aluminum, varying amounts of sulfates, gypsum, calcium carbonates, bicarbonates and trace amounts of silica, phosphate, manganese, titanium, copper and 
zinc. The hydrous nature and electrostatic charge on ferric hydroxide account for the poor settling of the sludge.

\subsubsection{Disposal of Acid Mine Drainage Sludge}

The AMD sludge generated at the treatment site was transported to its final disposal location, based on the distance of disposal site from the treatment site, by either a pipeline (200 feet to 1 mile) or a truck (one-half mile to 3 miles) (Ackman 1982). Four disposal methods were practiced: deep mine disposal, permanent retention in the settling ponds, disposing at a coal refuse area and onsite burial. The sludge was disposed off either into underground abandoned mines or inactive portions of active mines. The sludge is alkaline in nature and its disposal in an acidic environment provides neutralization and iron hydroxide does not readily go back into solution (Ackman 1982). However, access to the underground mines may be prohibited and the installation of pipelines is not economically feasible.

The settling ponds used at the treatment sites can also be used to permanently hold the sludge. However, fill-up of the ponds due to changing mine conditions and changing mine water quality is common and additional capital investment may be required. The advantage of retaining the sludge permanently in ponds is that this method does not require sludge transportation. The disadvantages are that reclamation of the ponds is difficult and it takes years for the sludge to dry, especially in the humid, temperate climate of Pennsylvania and West Virginia.

The third method of sludge disposal is using a coal refuse area. Shallow ponds, constructed at the site by dumping the refuse in a large circle forming a barrier, are filled with the sludge and covered by the refuse. The alkaline nature of the sludge helps in 
neutralizing the acidic nature in a coal refuse. The disadvantage of this method is the long hauling distances. The fourth method, onsite disposal is the least used method. The wet sludge is placed in a pond and covered with earthen materials.

\subsection{Sludge Dewatering}

Dewatering is a physical unit operation used to concentrate the total solids in the sludge by reducing the moisture content (water) in the sludge (Metcalf and Eddy 2000). The dewatering techniques use physical means like filtration, capillary action, centrifugal separation and compaction. Commonly used dewatering methods are vacuum filtration, pressure filtration, centrifugal filtration, sand drying beds and use of coagulants/flocculants.

\subsubsection{Vacuum Filtration}

Vacuum filtration is one of the most commonly used dewatering methods applied to wastewater sludge (Eckenfelder 2000). In vacuum filtration, the water in the sludge is sucked through a porous medium by applying vacuum and the solids are retained by the porous medium (McCabe et al. 1993). The porous medium is generally cloth, steel mesh or tightly wound coil springs.

Vacuum filtration is commercially applied using rotary-drum filters. A typical rotary-drum vacuum filtration apparatus is shown in Figure 2.4. In a rotary-drum filter, a rotary drum is immersed (12-60\%) into the wastewater slurry tank; vacuum is applied on the slurry, and the drum is rotated simultaneously. As the drum rotates, a cake is formed and water is removed through the cake and the porous media. A knife edge is provided at one end of the drum to remove the cake from the filter medium and the filter medium is 
washed with water before entering the wastewater slurry. The sludge is usually conditioned using polymers before the application of vacuum.

The efficiency of vacuum filtration depends on a number of variables like vacuum pressure, drum speed, type and porosity of the filter, solids concentration, viscosity of sludge and filtrate, sludge compressibility, chemical composition of the sludge and the nature of particles in the sludge (size, shape and water content) (Eckenfelder 2000).

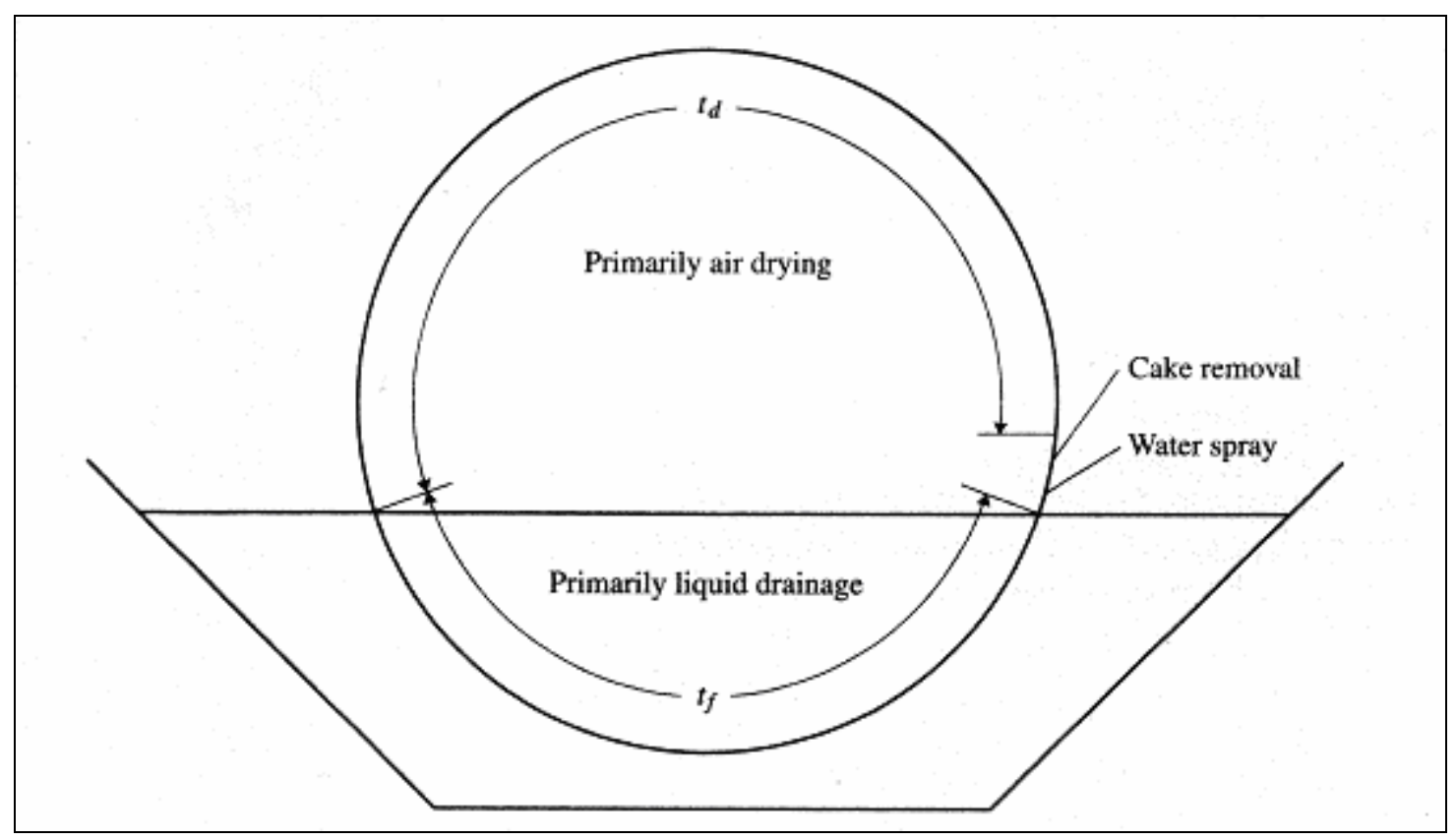

Figure 2.4: A typical vacuum filtration apparatus (Source: Eckenfelder 2000).

\subsubsection{Pressure Filtration}

Pressure filtration can be applied on almost all the water and wastewater sludges. In pressure filtration, the water in the sludge is forced through the filter medium by applying a pressure on the sludge and the solids are retained on the filter medium. Most wastewater sludges can be dewatered by pressure filtration to produce a $40-50 \%$ solids cake with 225-lb/in ${ }^{2}$ filters (Eckenfelder 2000). 
Pressure filtration is commercially applied using belt filters as shown in Figure 2.5. Belt filters are effective for almost all municipal wastewater sludges (Metcalf and Eddy 2000). There are three main stages in a belt filter; chemical conditioning, gravity drainage and sludge dewatering by the application of pressure. The sludge is conditioned by using polymers (Stage 1, Figure 2.5) and then introduced into the gravity drainage section where the sludge is thickened by removing the water from the sludge by gravity (Stage 2, Figure 2.5). The sludge is then squeezed between opposing porous cloth belts by the application of pressure (Stage 3, Figure 2.5). The squeezing induces the release of additional water from the sludge and the final cake obtained is removed from the filter belts by using scraper blades.

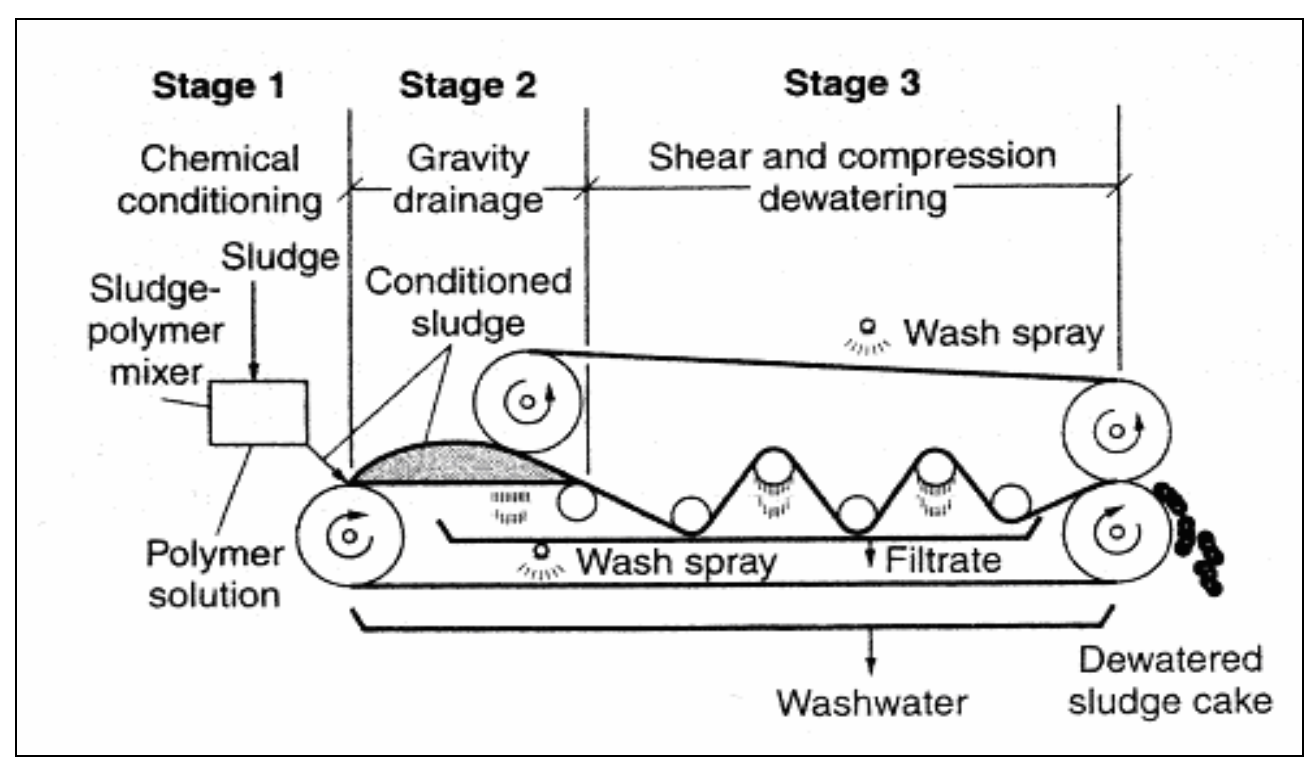

Figure 2.5: A typical belt filter apparatus

(Source: Metcalf and Eddy 2000).

\subsubsection{Centrifugation}

Centrifugation is generally used to separate liquids with different density, thicken the wastewater slurries or remove the solids from the sludge (Metcalf and Eddy 2000). 
Centrifugation is commercially applied using a solid-bowl centrifuge, as shown in Figure 2.6. In a solid-bowl centrifuge, sludge is fed at a constant rate into a rotating bowl. Centrifugal forces compact the sludge against the bowl wall forming a dense cake and the dilute stream, centrate, is separated from the compacted sludge. The centrate contains fine, low-density solids and is returned back to the wastewater treatment plant.

The cake is then discharged from the bowl to a conveyer belt. The solids content in the cake varies from $10-30 \%$ solids. The solid-bowl centrifuges can be used to dewater the sludge without pre-conditioning the sludge. However, the solids capture and centrate quality can be improved by chemical conditioning.

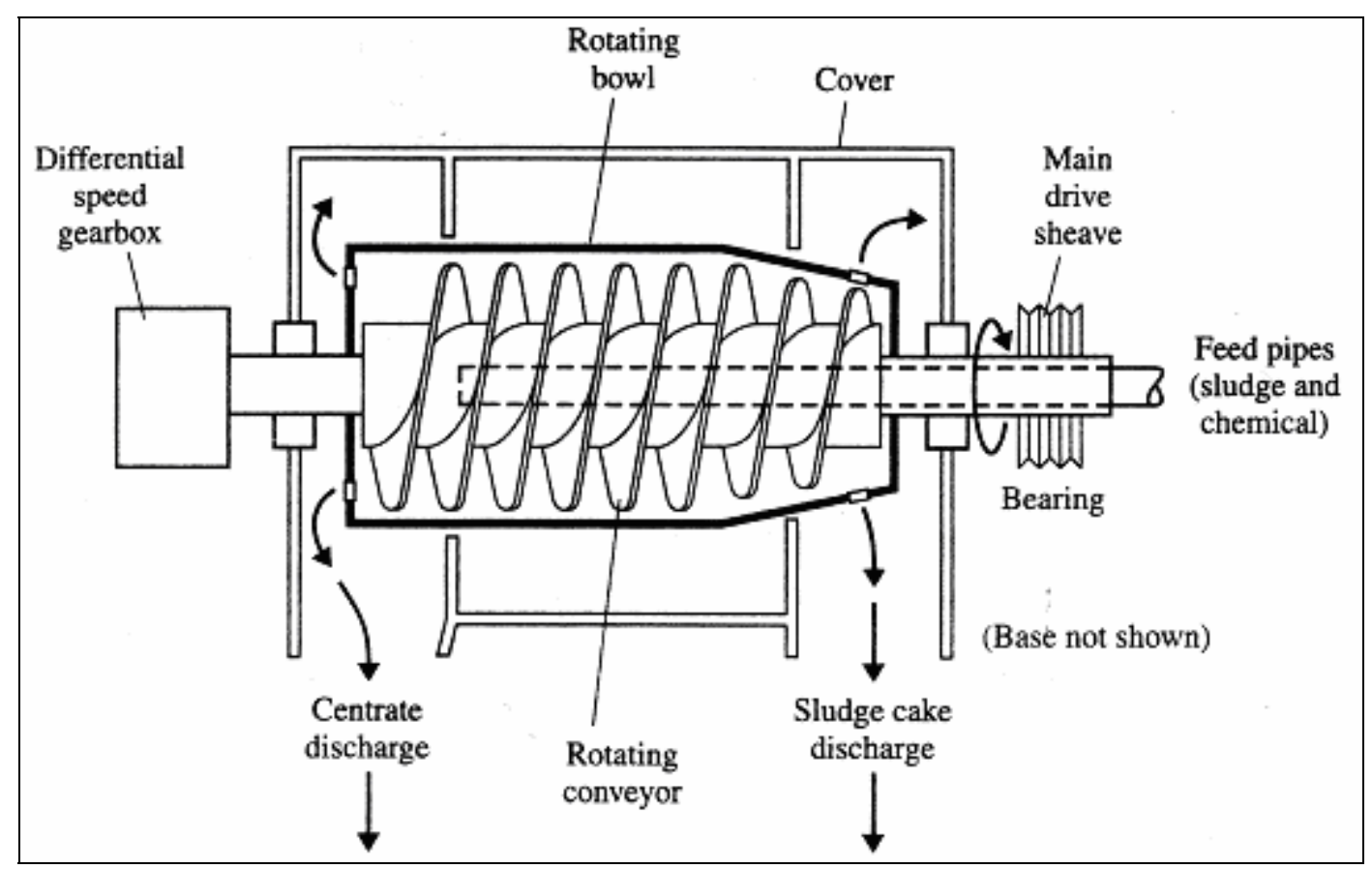

Figure 2.6: A typical solid-bowl centrifuge (Source: Eckenfelder 2000).

\subsubsection{Sand Drying Beds}

Conventional sand drying beds are used in the wastewater treatment plants of communities with a population $<20,000$ (Metcalf and Eddy 2000). In a sand drying bed, 
the sludge can be dewatered on open or covered sand beds through percolation and evaporation, as shown in Figure 2.7. The sludge is placed on a bed and allowed to dry and percolate. The sludge dewaters by drainage and by evaporation of surface exposed to the air. Most of the water is removed by draining rather than evaporation.

Sludge drying beds consist of 10-23 in of sand over a 20-46 in of graded gravel or stone (Eckenfelder 2000). The system should be provided with a proper under drainage system. The drying area of the beds is partitioned into individual beds so that one or more beds can be used in a loading period. The sludge can be removed from the drying beds after the sludge has drained and dried into a coarse, cracked surface and is black or dark brown in color. The total solids in the sludge vary from 30-50 \% solids. Sludge is usually removed manually using shovels or scrapers or special mechanical equipment.

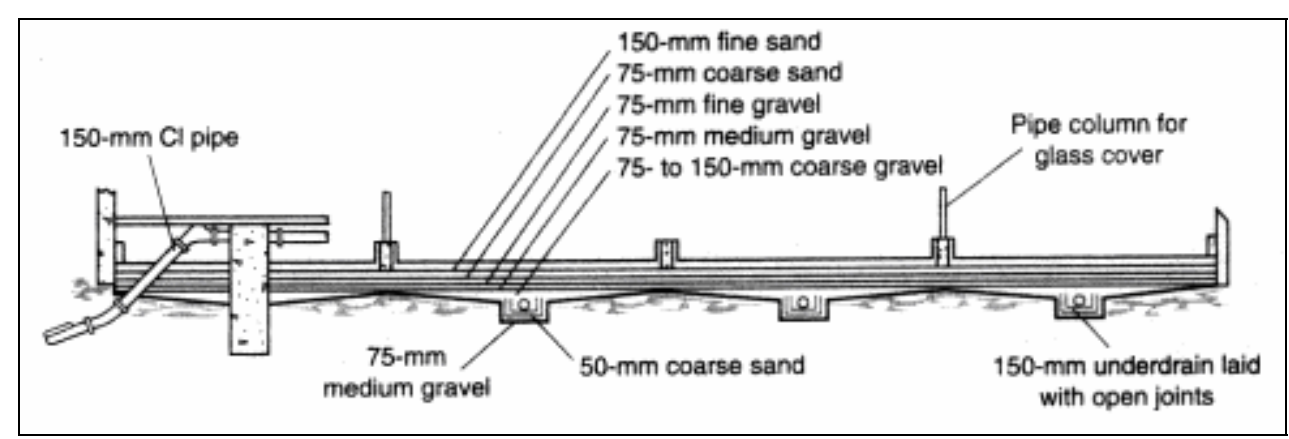

Figure 2.7: A typical sand drying bed (Source: Eckenfelder 2000).

\subsubsection{Coagulants and Flocculants}

Coagulation and flocculation are two different processes that facilitate the colloid settling in water. Coagulants reduce the net electrical repulsive forces at the particle surfaces promoting consolidation of smaller particles into larger particles. Flocculants combine the smaller particles by bridging the gaps between the particles with chemicals. 
Bridging takes place when the suspended particles are adsorbed by segments of a polymer chain bringing the smaller particles together to form larger particles. The settling velocity based on gravity of the larger particles is faster compared to the smaller particles.

The coagulants used in water treatment are alum $\left(\mathrm{Al}_{2}\left(\mathrm{SO}_{4}\right)_{3}\right)$, ferrous sulfate (FeSO4), ferric sulfate $\left(\mathrm{Fe}_{2}\left(\mathrm{SO}_{4}\right)_{3}\right)$, ferric chloride $\left(\mathrm{FeCl}_{3}\right)$, and sodium aluminate $\left(\mathrm{NaAlO}_{2}\right)$ (Skousen et al. 1993). Alum, a standard coagulant used in water treatment, reacts with alkalinity in water to form aluminum hydroxide which attracts other metals and causes their precipitation. However, the use alum may not be successful due to the formation of aluminum hydroxide which is the principle component of the treated AMD. As like repels like, aluminum hydroxide formed by the application of alum may not help in sludge settling. Ferrous sulfate behaves similarly to alum but reacts more slowly. Ferric sulfate is applicable over a large $\mathrm{pH}$ range compared to ferrous sulfate and the floc generated by the former is heavy and settles quickly. The use of sodium aluminate, which is alkaline unlike the other coagulants, is limited due to its high cost.

The flocculants used in water treatment are activated silica $\left(\mathrm{Na}_{4} \mathrm{SiO}_{4}\right)$, clays, metal hydroxides of aluminum and iron, and synthetic flocculants (anionic, cationic and non-ionic) (Skousen et al. 1993). The resulting floc using activated silica is larger, denser, more stable and settles quickly.

Synthetic flocculants contain large molecules, which when dissolved in water, produce highly charged ions. Anionic polymers form negatively charged ions and remove the positively charged ions and the reverse takes place with cationic polymers. Non-ionic polymers are neutral molecules, which when dissolved in water, release both positively 
and negatively charged ions. The quantity of synthetic polymers required is less than alum and metal hydroxide flocculants. 


\section{CHAPTER 3: INVESTIGATIVE APPROACH}

\subsection{Site Description}

An existing site was selected in the Monongalia County, West Virginia that treated acid mine drainage (AMD) from an abandoned underground mine. The site was a bond-forfeited mine site and thus active treatment was assumed by the Division of Mining and Reclamation (DMR) of the West Virginia Department of Environmental Protection (WVDEP). According to the data provided by WVDEP, acid mine water, pumped out of the mine, has a high metal content ( $\mathrm{Fe}$ and $\mathrm{Al}$ ), low $\mathrm{pH}$ (average $\mathrm{pH}=2.7$ ) and a high sulfate content (Table 3.1). The mean flow recorded by WVDEP was $88.8 \pm$ $71.9 \mathrm{gpm}$, but is highly variable (5.8-398.7 gpm).

Table 3.1: Raw water data from the site (Jan 1996 - Feb 2003) (Source: Data provided by WVDEP).

\begin{tabular}{cc}
\hline Property & Value \\
\hline $\begin{array}{c}\text { Specific Conductance } \\
(\mu \mathrm{S} / \mathrm{cm})\end{array}$ & $5,575 \pm 4,686$ \\
Acidity & $2,023 \pm 1,287$ \\
Total Suspended Solids & $48 \pm 117$ \\
Total Fe $(\mathrm{mg} / \mathrm{L})$ & $435.04 \pm 193.5$ \\
Total Al $(\mathrm{mg} / \mathrm{L})$ & $106.15 \pm 48.2$ \\
Total $\mathrm{Mn}(\mathrm{mg} / \mathrm{L})$ & $4.27 \pm 1.5$ \\
Total $\mathrm{SO}_{4}(\mathrm{mg} / \mathrm{L})$ & $2,063 \pm 926$ \\
\hline
\end{tabular}

A map of the AMD treatment operations at the site is presented in Figure 3.1. Hydrogen peroxide $\left(\mathrm{H}_{2} \mathrm{O}_{2}\right)$ and anhydrous ammonia $\left(\mathrm{NH}_{3}\right)$ are added in the treatment 
channel immediately after the water is pumped from the underground mines. After chemical addition, the treated water is sent into a treatment pond (also referred to as "primary settling pond") where insoluble metal hydroxides settle at the bottom (indicated as "A" in Figure 3.1) and clarified water is removed from the surface. After settling, the sludge is sent into drying ponds, indicated as "1", "2" and "3", where additional clarified water is removed and the sludge is allowed to dry. Additional settling ponds represented as "B", "D" and "C" are used when the drying ponds "1", "2" and "3" are completely full. However, the daily usage of these settling ponds is not common.

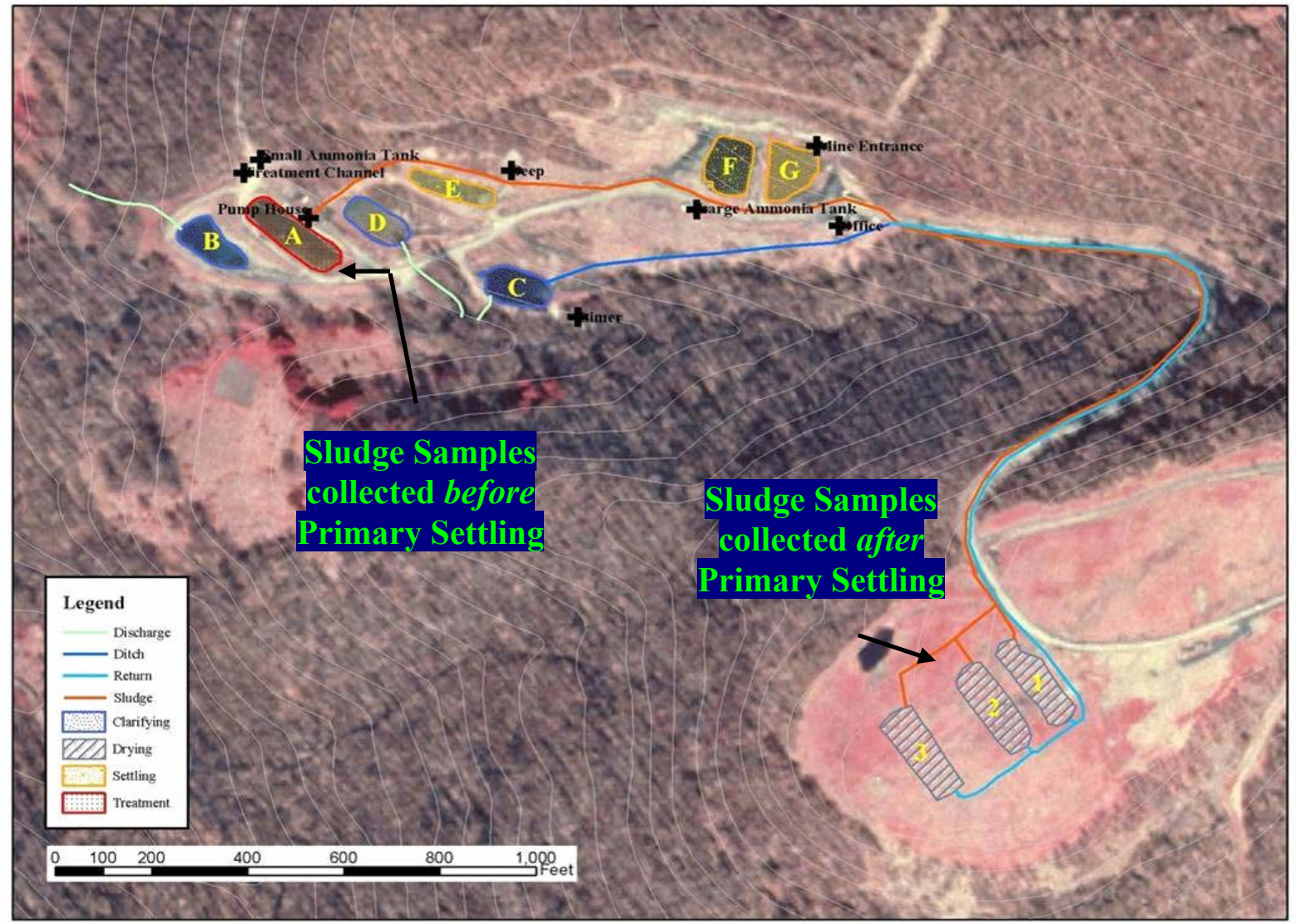

Figure 3.1: Site map of the AMD treatment at the site.

A picture of the treatment channel where hydrogen peroxide $\left(\mathrm{H}_{2} \mathrm{O}_{2}\right)$ and anhydrous ammonia $\left(\mathrm{NH}_{3}\right)$ are added is shown in Figure 3.2. Hydrogen peroxide oxidizes 
the metals present in the acid mine water, to their respective insoluble metal hydroxides. Ammonia, a strong base, neutralizes the acidity and raises the $\mathrm{pH}$ of AMD.

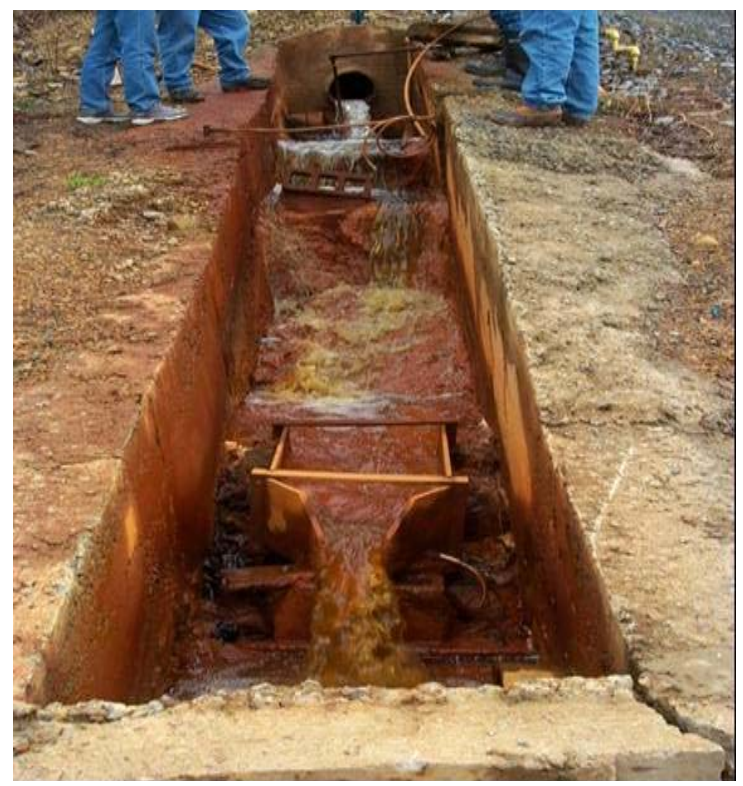

Figure 3.2: Addition of $\mathrm{H}_{2} \mathrm{O}_{2}$ and $\mathrm{NH}_{3}$ to the acid mine water at the site.

A picture of the treatment pond, represented as "A" in Figure 3.1, which is also referred to as the primary settling pond is shown in Figure 3.3.

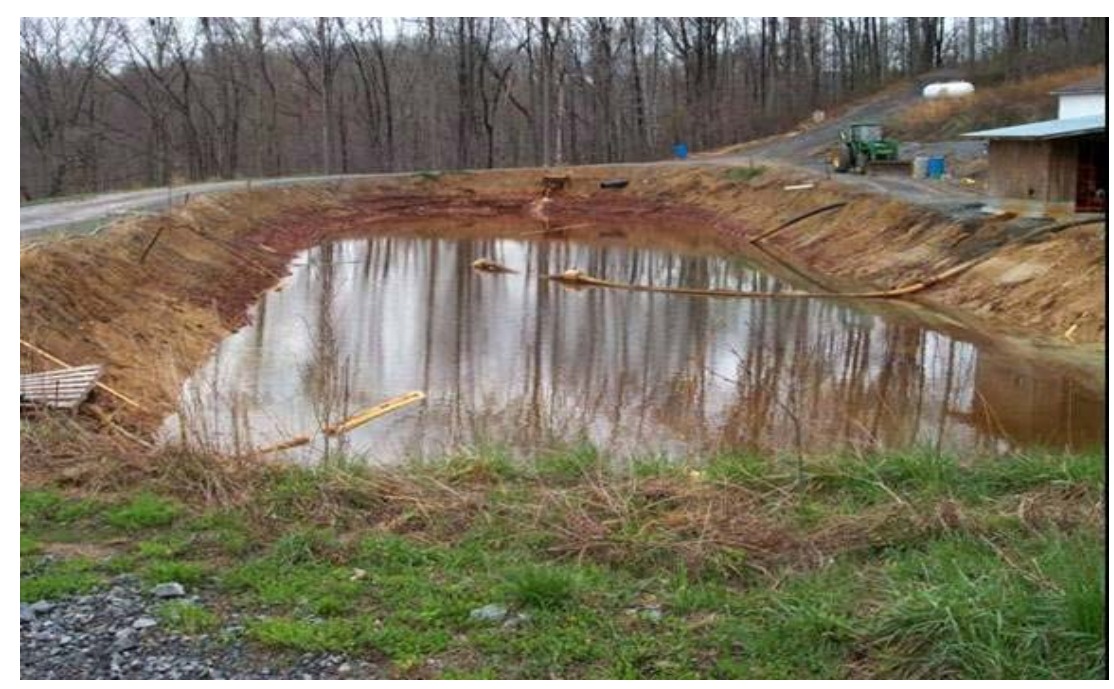

Figure 3.3: Primary settling pond "A".

A picture of the drying pond where the sludge is allowed to dry is shown in

Figure 3.4 and a picture of the dried sludge is shown in Figure 3.5. 


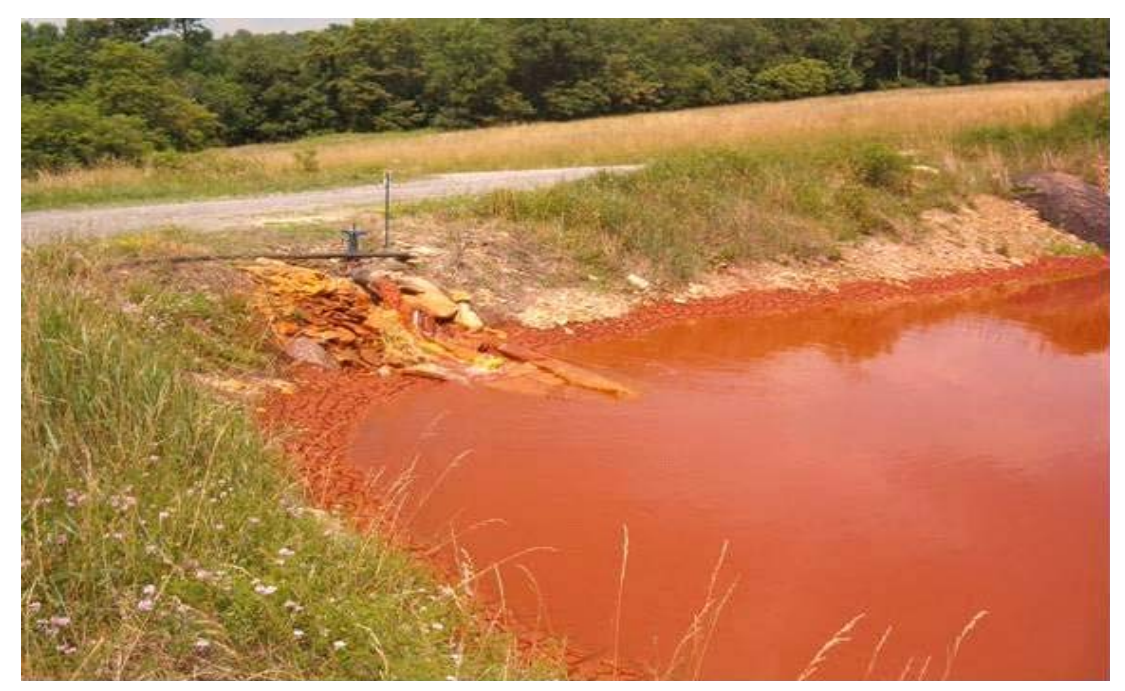

Figure 3.4: A drying pond.

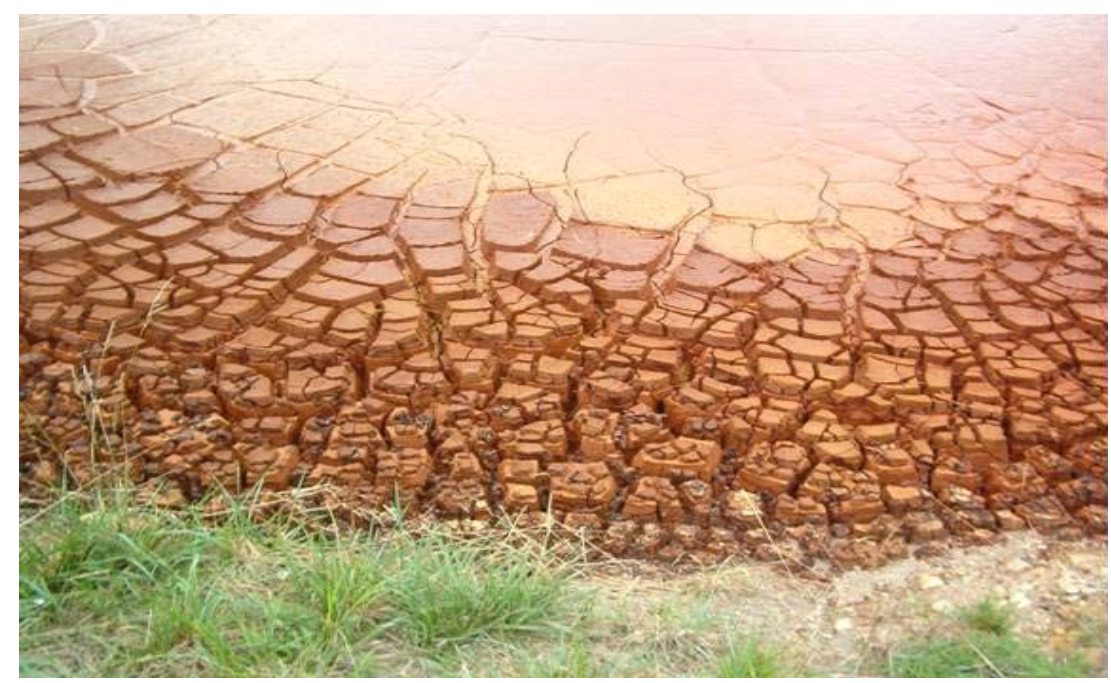

Figure 3.5: Dried sludge.

\subsection{Materials and Methods}

\subsubsection{Sample Collection}

There were two experiments conducted in this research. The first experiment was conducted to determine if aging, storage temperature $\left(4^{\circ} \mathrm{C}\right.$ and $\left.20^{\circ} \mathrm{C}\right)$ and mixing affect the dewatering of AMD sludge which would further affect our approach to treatability. The sludge samples were collected after primary settling and prior to entering the drying 
ponds on September 15, 2003, represented as Point 2 in Figure 3.6 using Encore Plastics 3.5 and 5 gallon (U.S.) buckets.

The second experiment was conducted to study the effectiveness of dewatering treatment methods on the sludge collected before and after primary settling. The sludge samples collected before and after primary settling are represented as Point 1 and 2 respectively in Figure 3.6 and were collected in a similar manner to that of the aging experiment. The four sludge samples from Point 1 were collected on June 1, 3, 8 and 10 of 2004. Pumping frequency of the sludge to the drying ponds was irregular due to inadequate accumulation of the sludge in the primary settling pond and was a problem during sample collection at Point 2. The four sludge samples collected from Point 2 were collected on June 14, 22 and July 1, 19 of 2004 respectively.

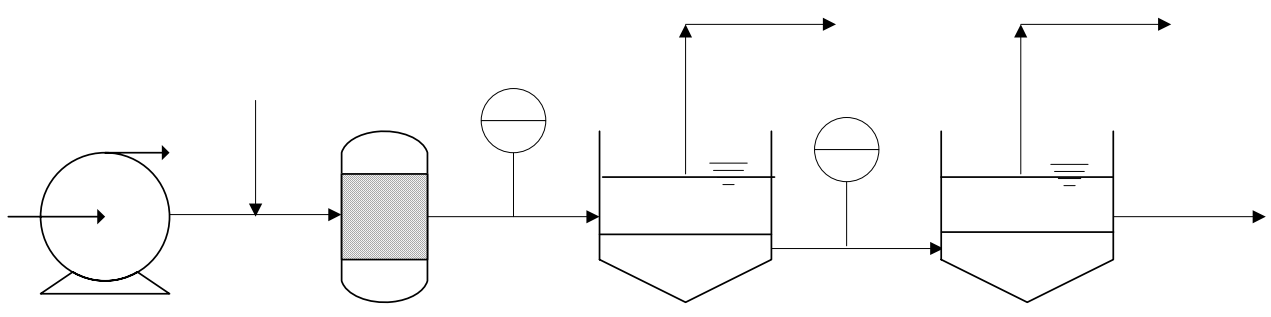

Figure 3.6: Schematic of the two sample collection points at the site.

\subsubsection{Sludge Characterization Methods}

The properties used to characterize the sludge in the aging experiment were $\mathrm{pH}$, specific conductance, percent settled sludge, viscosity, specific resistance to filtration (SRF) and particle size distribution. The properties used to characterize the sludge in the dewatering experiment were $\mathrm{pH}$, specific conductance, percent settled sludge, viscosity 
and specific resistance to filtration (SRF). The instruments used for these analyses are given in Table 3.3. All properties were measured in triplicate except $\mathrm{pH}$ and specific conductance, for which single readings were taken.

Table 3.2: Instruments and methods used for characterization of sludge samples.

\begin{tabular}{ccc}
\hline Parameter & Manufacturer \& Model & Method \\
\hline $\mathrm{pH}$ & YSI 63 & - \\
Specific Conductance & YSI 63 & - \\
Percent Settled Sludge & - & Jar Settling \\
Viscosity & Brookfield DV-III \\
Specific Resistance to & Programmable Rheometer & \\
Filtration & - & Buchner Funnel \\
Particle Size Distribution & Beckmann Coulter LS 230 & Standard Method 2560 D** \\
Total Solids & - & Standard Method 2540 B \\
Total Suspended Solids & - & Standard Method 2540 D \\
\hline
\end{tabular}

\subsubsection{1 pH and Specific Conductance}

pH and specific conductance were measured using a YSI Model 63 meter. The YSI model 63 meter was calibrated immediately before use with buffer solutions of $\mathrm{pH} 7$ and $\mathrm{pH} 10$ in a two-point calibration following the standard procedure given in the manufacturer's manual. The $\mathrm{pH}$ and specific conductance were measured by completely immersing the probe in the samples.

\subsubsection{Percent Settled Sludge}

Percent settled sludge was measured using the jar settling test procedure previously developed by WVU-CEE researchers. The sludge $(400-500 \mathrm{ml})$ was placed 
in a $600 \mathrm{ml}$ beaker and mixed for 4 minutes at $100 \mathrm{rpm}$ with a Phipps and Bird stirrer. The total height of the sludge was measured and the sludge was allowed to settle, undisturbed, for 24 hours. The height of the settled sludge was then measured. As part of work developed by other investigators in the study, it was determined that the sludge does not settle significantly after 24 hours (Figure 3.7). The measurement of percent settled sludge is shown in Figure 3.8.

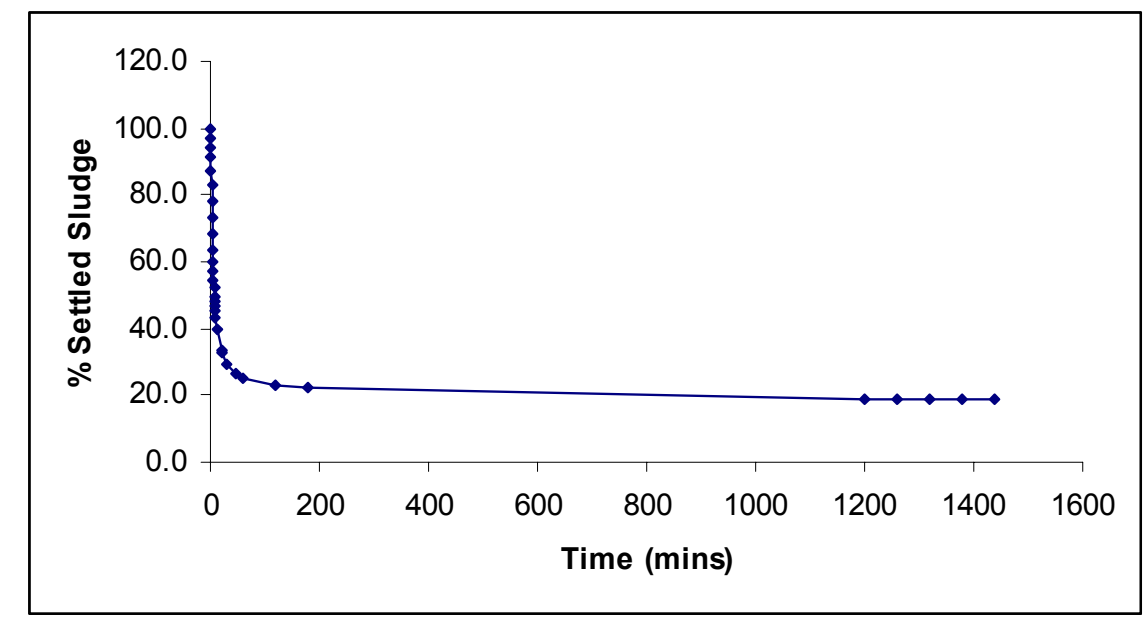

Figure 3.7: Variation in percent settled sludge with time.

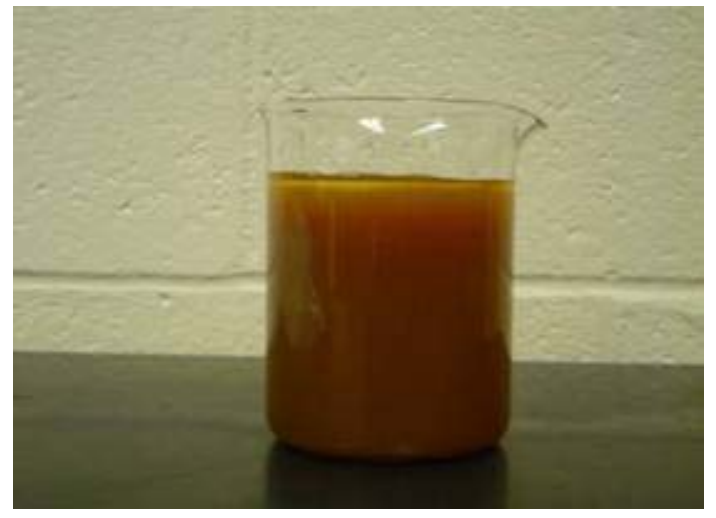

(a)

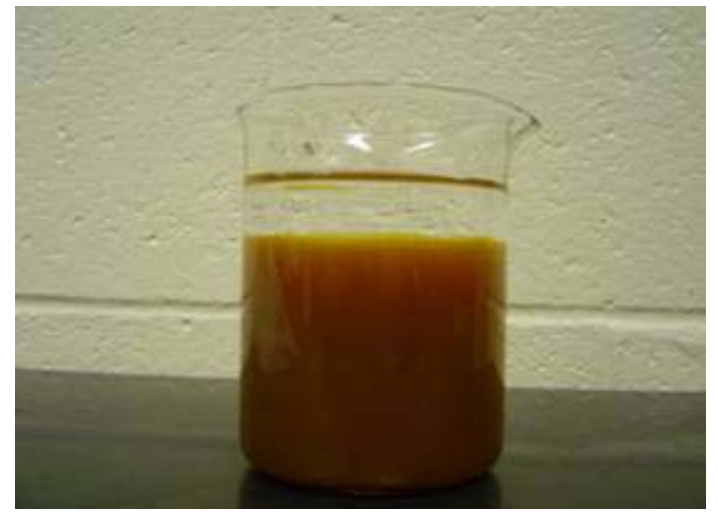

(b)

Figure 3.8: Measurement of percent settled sludge (a) Initial and (b) after $24 \mathrm{hrs}$.

The percent settled sludge is calculated as shown in Equation 3.1. 


$$
\% S S=100-\left[\left(\frac{H_{i}-H_{f}}{H_{i}}\right) \times 100\right]
$$

\section{Equation 3.1}

where,

$$
\begin{gathered}
\text { SS = Settled Sludge, } \% \\
\mathrm{H}_{\mathrm{i}}=\text { Initial Height of the Sludge, cm } \\
\mathrm{H}_{\mathrm{f}}=\text { Final Height of the Sludge, } \mathrm{cm}
\end{gathered}
$$

\subsubsection{Viscosity}

Viscosity was measured using a Brookfield Model DV-III Programmable Rheometer using the LV-1 and LV-4 spindles of the LV spindle set. The LV-4 spindle was used to measure the viscosity of thin sludge (percent initial total solids $<2.0 \%$ ) and LV-1 spindle was used for thick sludge (percent initial total solids $>2.0 \%$ ).

Percent torque was measured by the rheometer over a speed range of 0-250 rpm, where the following step changes in speed were made: $1 \mathrm{rpm}$ interval from 1-5 rpm, 5 rpm interval from 5-50 rpm and $10 \mathrm{rpm}$ interval from 50-250 rpm. All readings were taken after the rheometer displayed a fixed, stable $\%$ torque reading. The motor was turned off after every reading to ensure that the fluid was completely stable before rotating the spindle. Shear stress and shear strain were calculated from the \% torque readings as shown in Equations 3.2 and 3.3 (Brookfield Engineering 1999).

Shear Rate, S, (1/sec):

$$
S=\left[\frac{2 \times \omega \times R_{c}{ }^{2} \times R_{b}{ }^{2}}{X^{2} \times\left(R_{c}{ }^{2}-R_{b}{ }^{2}\right)}\right]
$$

Shear Stress, F, (dynes/cm²):

$$
F=\left[\frac{M}{2 \times \pi \times R_{b}{ }^{2} \times L}\right]
$$

\section{Equation 3.3}


where,

$$
\begin{aligned}
& \omega=\text { angular velocity of the spindle }(\mathrm{rad} / \mathrm{sec}) \\
& =\frac{(2 \times \pi \times N)}{60} \\
& \mathrm{~N}=\mathrm{rpm} \quad \pi \cong 3.14 \\
& \mathrm{R}_{\mathrm{c}}=\text { radius of the container }(\mathrm{cm})=4.3 \mathrm{~cm} \\
& \mathrm{R}_{\mathrm{b}}=\text { radius of the spindle }(\mathrm{cm}) \\
& =0.160 \mathrm{~cm}(\mathrm{LV}-1 \text { spindle }) \\
& =0.942 \mathrm{~cm}(\mathrm{LV}-4 \text { spindle }) \\
& =3.101 \mathrm{~cm}(\mathrm{LV}-1 \text { spindle }) \\
& =6.510 \mathrm{~cm}(\mathrm{LV}-4 \text { spindle })
\end{aligned}
$$

\section{Equation 3.4}

The shear stress and shear rates, calculated from \% torque, were plotted on a linear scale from which viscosity was determined by the slope. A sample plot for the determination of viscosity is shown in Figure 3.9. 


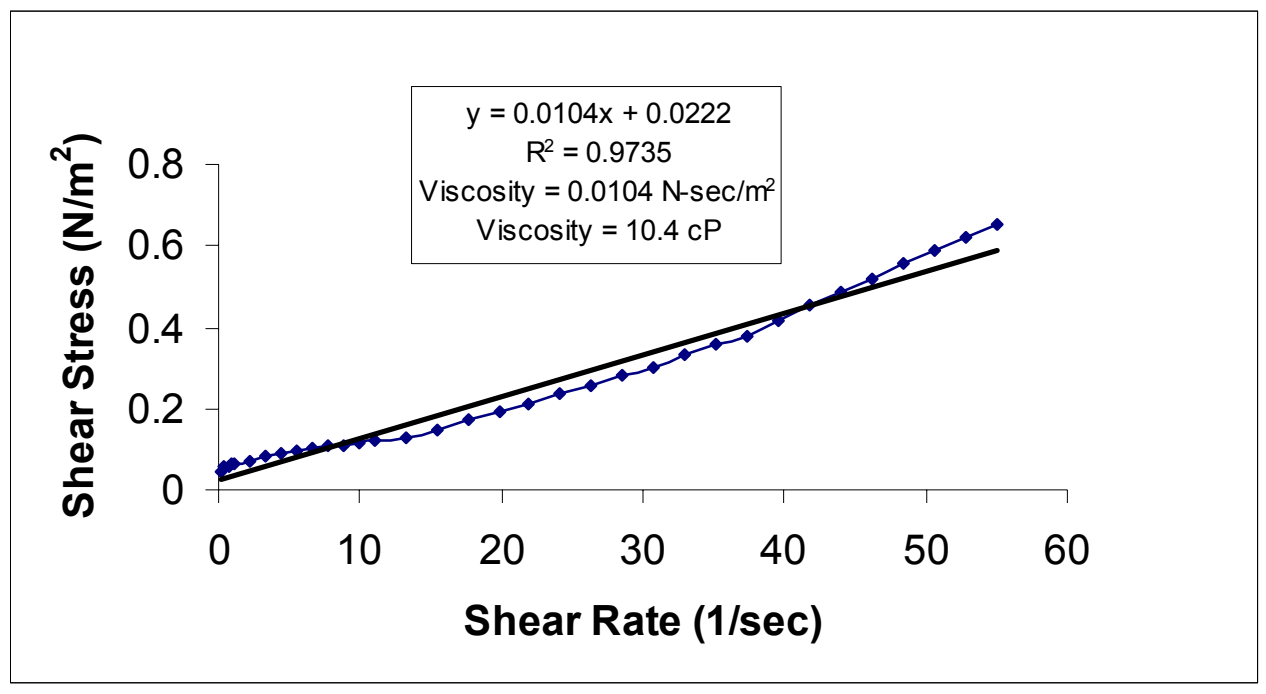

Figure 3.9: A sample plot for determination of viscosity.

\subsubsection{Specific Resistance to Filtration (SRF)}

Specific resistance to filtration (SRF), a measure of filterability, is defined as "the pressure difference required producing a unit filtration flow rate with unit viscosity through a unit weight of the cake" (Eckenfelder 2000). As the SRF of the sludge increases, it becomes more difficult to filter. SRF of the sludge was measured in the laboratory using the Buchner Funnel Test, with a vacuum of 50,796 $\mathrm{Pa}$ (15 in $\mathrm{Hg}$ ). The procedure described by Eckenfelder was used with a sample volume of $180 \mathrm{ml}$. The SRF is calculated from the Buchner Funnel test as shown in Equations 3.5 and 3.6 (Eckenfelder 2000).

$$
S R F=\left[\frac{\left(2 \times P \times b \times A^{2}\right)}{(\mu \times C)}\right]
$$

\section{Equation 3.5}

Where,

$$
\mathrm{SRF}=\text { specific resistance to filtration, } \mathrm{s}^{2} / \mathrm{g}
$$




$$
\begin{aligned}
& \mathrm{P}=\text { filter pressure }(15 \text { inches of } \mathrm{Hg}), \mathrm{g} / \mathrm{cm}^{2} \\
& \mathrm{~b}=\text { slope of the plot }(\mathrm{V} \text { versus } \mathrm{t} / \mathrm{V}), \mathrm{s} / \mathrm{cm}^{6} \\
& \mathrm{~V}=\text { filtrate volume in a time interval }(\mathrm{t}), \mathrm{ml} \\
& \mathrm{A}=\text { filter area of the Buchner Funnel, } \mathrm{cm}^{2} \\
& \mu=\text { viscosity, } \mathrm{P} \\
& \mathrm{C}=\text { weight of solids / unit volume of sludge, } \mathrm{g} / \mathrm{ml}
\end{aligned}
$$

C is calculated as follows:

$$
C=\frac{1}{\left[\left(\frac{C_{i}}{100-C_{i}}\right)-\left(\frac{C_{f}}{100-C_{f}}\right)\right]}
$$

\section{Equation 3.6}

Where,

$$
\begin{aligned}
& \mathrm{C}_{\mathrm{i}}=\text { initial moisture content, } \% \\
& \mathrm{C}_{\mathrm{f}}=\text { final moisture content, } \%
\end{aligned}
$$

\subsubsection{Particle Size Distribution}

Particle size distribution was measured using a Coulter LS 230 Particle Size Analyzer (Figure 3.9), using the variable speed fluid module plus and the polarization intensity differential scattering (PIDS) system. Standard method 2560 D Light-Scattering Method was used for particle size analysis (APHA 1998). The particle size results were represented using non-spherical and volume $\%$ methods. Mean, median and mode of the particle size was provided as output of a single run of which mean ( \pm standard deviation) and mode of the particle size distribution were used to present the results. 


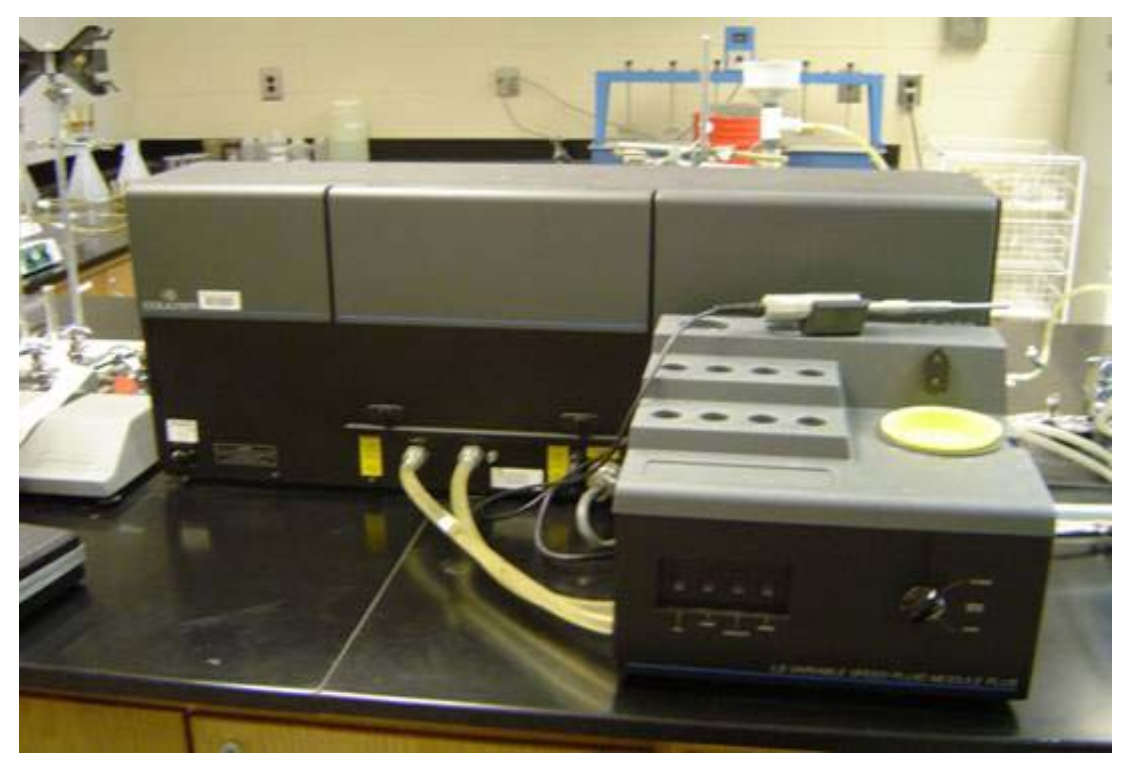

Figure 3.10: Coulter LS Series Particle Size Analyzer.

\subsubsection{Total Solids and Total Suspended Solids}

Percent solids were measured, after drying the sludge (for total solids) or the filter cake (for total suspended solids) at $105^{\circ} \mathrm{C}$ for 24 hours, using the following formula:

$$
\% \text { T.S. }=\left[\frac{\left(F_{w}-D_{w}\right)}{\left(I_{w}-D_{w}\right)}\right] \times 100
$$

Equation 3.7

where,

$$
\begin{aligned}
& \% \text { TS }=\text { total solids, } \% \\
& F_{w}=\text { weight of the sample }+ \text { dish after drying for } 24 \text { hours in an oven at } 105^{\circ} \mathrm{C} \\
& D_{w}=\text { dry weight of the dish } \\
& I_{w}=\text { weight of the sample }+ \text { dish weight }
\end{aligned}
$$

\subsubsection{Aging Experiments}

The sludge samples were stored in either refrigerator $\left(4^{\circ} \mathrm{C}\right)$ or at room temperature $\left(20^{\circ} \mathrm{C}\right)$ and sampled either weekly or at a longer interval of time $(4,6$ and 8 weeks). The 
samples were vigorously mixed for at least 30 minutes to assure homogeneity. This was done because the sludge settled quickly and agglomerated, thereby increasing the particle size rapidly over time. The sludge samples were characterized for $\mathrm{pH}$, specific conductance, percent settled sludge, viscosity, specific resistance to filtration (SRF) and particle size distribution using the methods discussed previously. The aging experiment was conducted over a duration of 8 weeks. Percent increase or decrease in the sludge properties, if any, were calculated to assess the effects of aging, temperature and mixing as shown in Equation 3.8.

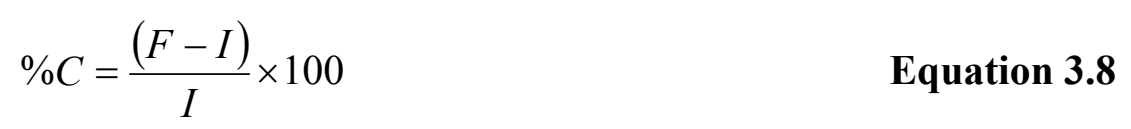

where,

$$
\begin{aligned}
& \mathrm{C}=\text { change in the value of the sludge property (increase or decrease) } \\
& \mathrm{F} \text { = final value of the sludge property } \\
& \mathrm{I} \text { = initial value of the sludge property }
\end{aligned}
$$

\subsubsection{Dewatering Experiment}

The dewatering experiment was conducted to study the effectiveness of dewatering treatment methods on the sludge samples collected before and after primary settling, after the optimum sludge storage conditions were established. The results from the aging experiment would provide an insight for any variations in dewatering of AMD sludge. This experiment was performed to determine the most effective approach to dewater sludge at the site. The following were the three objectives of the dewatering studies:

1. Determine which of the three dewatering methods worked on the sludge samples collected either before or after primary settling. 
2. Determine which of the three dewatering methods worked best on the sludge samples collected before or after primary settling.

3. Compare the best method for the sludge samples collected before primary settling with the best method for the sludge samples collected after primary settling. Assessments of performance were based on volume of water removed from the sludge, percent total solids, efficiency and concentration factor. The volume of water removed from the samples was directly measured using a graduate cylinder. Efficiency was calculated based on the volume of water removed compared to the initial volume of the sludge and concentration factor, based on the final total solids to the initial total solids (Equations 3.9 and 3.10).

$$
\begin{aligned}
& E=\left(\frac{V_{f}}{V_{i}}\right) \times 100 \\
& C=\left(\frac{T S_{f}}{T S_{i}}\right)
\end{aligned}
$$

where,

$$
\begin{aligned}
& E=\text { efficiency } \\
& V_{f}=\text { volume of water removed, } \mathrm{ml} \\
& \mathrm{V}_{\mathrm{i}}=\text { initial volume of the sludge, } \mathrm{ml} \\
& \mathrm{C}=\text { concentration factor } \\
& \mathrm{TS}_{\mathrm{f}}=\text { final total solids, } \mathrm{g} / \mathrm{g} \\
& \mathrm{TS}_{\mathrm{i}}=\text { initial total solids, } \mathrm{g} / \mathrm{g}
\end{aligned}
$$

The sludge samples were analyzed immediately after collection, for characteristics and dewatering experiments in the laboratory. The sludge samples were characterized for $\mathrm{pH}$, specific conductance, percent settled sludge, viscosity and specific 
resistance to filtration (SRF). Four sludge samples before primary settling and four sludge samples after primary settling were collected between June and July 2004 for dewatering experiments.

Three dewatering methods were evaluated; vacuum filtration, pressure filtration and flocculant addition. Vacuum filtration was assessed using the Buchner Funnel apparatus at a vacuum of $50,796 \mathrm{~Pa}(15 \mathrm{in} \mathrm{Hg}$ ) on $180 \mathrm{ml}$ of the sample. Whatman No 2 filter paper, with a medium fine porosity and a particle retention $>8 \mu \mathrm{m}$, was used for vacuum filtration. All the measurements were made in triplicate. The volume of water removed from the sludge is referred to as filtrate volume. Filtrate volume and percent total solids were measured after the application of vacuum filtration, from which the efficiency and concentration factor were calculated, to determine the effectiveness of vacuum filtration.

Pressure filtration was assessed using an Amicon test cell, Model 8200, at a pressure of 137,895 $\mathrm{Pa}(20 \mathrm{psi})$. The same parameters and procedures used for vacuum filtration were applied in pressure filtration tests.

Flocculants used in the study were Calloway 4910, Alco Clear ACP and Accophos 1250 . Based on the work done by other investigators in the study, Calloway 4910 is a cationic polymer which decreases sludge volume. Alco Clear ACP and Acco-phos 1250 are anionic polymers which form a good floc and accelerate the settling time of the sludge. The flocculants were used at concentrations of 0 (control), 20, 40, 60 and 120 ppm. Based on the procedure developed previously by WVU-CEE researchers (presented in Appendix D), the sludge was mixed for 2 minutes at $100 \mathrm{rpm}$; a $0.1 \%$ solution of 
flocculant was added and then again mixed for 2 minutes at $100 \mathrm{rpm}$. Percent settled sludge was measured after 24 hours.

For flocculant addition experiments, the volume of water removed from the sludge is referred to as clarified volume. Clarified volume was measured after the treated sludge had settled for 24 hours, and was separated from the settled sludge with a syringe. Percent total solids was measured after removing the clarified water and mixing the settled sludge. Readings were taken in triplicate for controls $(0 \mathrm{ppm})$ and single readings for flocculant addition at concentrations of 20, 40, 60 and $120 \mathrm{ppm}$.

\subsubsection{Vacuum Filtration after Flocculant Addition}

An experiment was conducted to determine the effectiveness of vacuum filtration after the addition of the flocculant, Acco-Phos 1250, on the sludge collected before primary settling. Similar procedure described previously was used for flocculant addition and vacuum filtration. However, to account for $120 \mathrm{ppm}$ flocculant concentration, approximately $22 \mathrm{ml}$ of the $0.1 \%$ flocculant solution was added to $180 \mathrm{ml}$ of the sludge sample. Vacuum filtration was then performed on $202 \mathrm{ml}(180 \mathrm{ml}+22 \mathrm{ml})$ of the sludge sample by continuously adding the solution to the Buchner Funnel apparatus. All the measurements were made in triplicate.

\subsubsection{Statistical Analysis}

The statistical analyses performed in the aging experiment and the dewatering experiment are shown in Tables 3.3 and 3.4 respectively. The statistical methods used in the aging experiment were two sample $t$-test, Kruskal-Wallis test, and Mann-Whitney rank sum test. The statistical methods used in the dewatering experiment were two 
sample $t$-test, Kruskal-Wallis test, analysis of variance (ANOVA), and multiple comparision test.

Table 3.3: Statistical methods used in the aging experiment.

\begin{tabular}{|c|c|c|c|}
\hline Aging Experiment & $t$-test & Kruskal-Wallis & $\begin{array}{c}\text { Mann- } \\
\text { Whitney }\end{array}$ \\
\hline $\mathrm{pH}$ & $x$ & $x$ & $x$ \\
\hline Specific Conductance & $x$ & $x$ & $x$ \\
\hline Percent Settled Sludge & $\sqrt{ }$ & $\sqrt{ }$ & $x$ \\
\hline Viscosity & $x$ & $x$ & $x$ \\
\hline $\begin{array}{l}\text { Specific Resistance to } \\
\text { Filtration (SRF) }\end{array}$ & $x$ & $x$ & $x$ \\
\hline $\begin{array}{l}\text { Particle Size } \\
\text { Distribution }\end{array}$ & $\sqrt{ }$ & $\sqrt{ }$ & $\sqrt{ }$ \\
\hline
\end{tabular}


Table 3.4: Statistical methods used in the dewatering experiment.

\begin{tabular}{|c|c|c|c|c|c|}
\hline $\begin{array}{l}\text { Dewatering } \\
\text { Experiment }\end{array}$ & & $t$-test & ANOVA & $\begin{array}{l}\text { Kruskal- } \\
\text { Wallis }\end{array}$ & $\begin{array}{c}\text { Multiple } \\
\text { Comparision }\end{array}$ \\
\hline $\begin{array}{l}\text { Comparision of } \\
\text { Sludge } \\
\text { Characteristics }\end{array}$ & & $\sqrt{ }$ & $x$ & $x$ & $x$ \\
\hline \multicolumn{6}{|l|}{$\begin{array}{l}\text { Before Primary } \\
\text { Settling }\end{array}$} \\
\hline Vacuum Filtration & & $x$ & $x$ & $x$ & $x$ \\
\hline Pressure Filtration & & $x$ & $x$ & $x$ & $x$ \\
\hline \multirow[t]{3}{*}{ Flocculant Addition } & $\begin{array}{l}\% \text { Settled } \\
\text { Sludge }\end{array}$ & $x$ & $\sqrt{ }$ & $x$ & $\sqrt{ }$ \\
\hline & \% Total Solids & $x$ & $\sqrt{ }$ & $x$ & $\sqrt{ }$ \\
\hline & $\begin{array}{l}\text { Clarified } \\
\text { Volume }\end{array}$ & $x$ & $\sqrt{ }$ & $\sqrt{ }$ & $\sqrt{ }$ \\
\hline \multicolumn{6}{|l|}{$\begin{array}{l}\text { After Primary } \\
\text { Settling }\end{array}$} \\
\hline Vacuum Filtration & & $x$ & $x$ & $x$ & $x$ \\
\hline Pressure Filtration & & $x$ & $x$ & $x$ & $x$ \\
\hline \multirow[t]{3}{*}{ Flocculant Addition } & $\begin{array}{l}\% \text { Settled } \\
\text { Sludge }\end{array}$ & $\mathrm{x}$ & $\sqrt{ }$ & $x$ & $x$ \\
\hline & $\%$ Total Solids & $x$ & $\sqrt{ }$ & $x$ & $x$ \\
\hline & $\begin{array}{l}\text { Clarified } \\
\text { Volume }\end{array}$ & $x$ & $\sqrt{ }$ & $x$ & $x$ \\
\hline
\end{tabular}

\subsubsection{Two Sample t-Test}

The two sample $t$-test (Zar 1999) was performed to determine whether or not there was a statistical difference between the properties of the sludge samples collected before primary settling to the sludge samples collected after primary settling from the dewatering experiment. The two sample $t$-test was also performed to determine whether or not there were significant differences between properties of the sludge (percent settled sludge and particle size distribution) affected by mixing, in the aging experiment. The 
properties of sludge samples from weeks 4 and 6 (mixed weekly) were compared with the properties of sludge samples from weeks 4 and 6 (mixed at longer intervals of time) respectively, to analyze the effects of mixing.

The two sample $t$-test takes two hypotheses into consideration, $\mathrm{H}_{\mathrm{o}}$ and $\mathrm{H}_{\mathrm{A}} . \mathrm{H}_{\mathrm{o}}$ is the hypothesis that there is no significant difference between the two samples and $\mathrm{H}_{\mathrm{A}}$ is the hypothesis that there is significant difference between the two samples. If the two samples have equal variances, then a $t$ value is calculated for the samples having $n$ measurements as shown in Equations 3.11-3.14 (Zar 1999).

$$
S S_{i}=\sum\left(X_{i}-\bar{X}\right)^{2}
$$

Equation 3.11

where,

$$
\begin{aligned}
& \mathrm{SS}_{\mathrm{i}}=\text { sum of squares of deviation for sample population, } i \\
& X_{i}=\text { measurements in a sample group } i \\
& \bar{X}=\text { population mean }
\end{aligned}
$$

$$
S_{p}^{2}=\frac{S S_{1}+S S_{2}}{v_{1}+v_{2}}
$$

where,

$$
\begin{aligned}
& v_{i}=n_{i}-1, \text { degrees of freedom } \\
& S_{p}{ }^{2}=\text { pooled variance } \\
& S_{\bar{X}_{1}-\bar{X}_{2}}=\sqrt{\frac{S_{p}^{2}}{n_{1}}-\frac{S_{p}^{2}}{n_{2}}}
\end{aligned}
$$

where,

$$
S_{\bar{X}_{1}-\bar{X}_{2}}=\text { standard error of the difference between the sample means }
$$




$$
t=\frac{\bar{X}_{1}-\bar{X}_{2}}{S_{\bar{X}_{1}-\bar{X}_{2}}}
$$

\section{Equation 3.14}

In the two sample $t$-test, the hypothesis $\mathrm{H}_{0}$ is rejected if $|t| \geq t_{\alpha(2), v}$ and the hypothesis $\mathrm{H}_{\mathrm{A}}$ is accepted (Zar 1999). $t_{\alpha(2), v}$ value is obtained from the tables for critical values of the $t$ distribution. $P$ is the probability of wrongly concluding the hypothesis $\mathrm{H}_{\mathrm{A}}$. In the statistical analysis, a 95\% level of confidence, $\alpha=0.05$ and $P=0.05$ was used and it is assumed that the hypothesis $\mathrm{H}_{\mathrm{A}}$ is true for $P<0.05$.

\subsubsection{Mann-Whitney Rank Sum Test}

Mann-Whitney Rank Sum Test is used to determine the statistical difference in two samples having non-normal data distributions (Zar 1999). The Mann-Whitney Rank Sum Test was performed to determine whether or not there was a statistical difference between the properties of the sludge affected by mixing in the aging experiment, for nonnormal data distributions. Two hypotheses are considered in this test, $\mathrm{H}_{\mathrm{o}}$ and $\mathrm{H}_{\mathrm{A}} \cdot \mathrm{H}_{\mathrm{o}}$ is the hypothesis that there is no significant difference between the two samples and $\mathrm{H}_{\mathrm{A}}$ is the hypothesis that there is significant difference between the two samples. In this test, the data are ranked either from smallest to largest or largest to the smallest values, and then the Mann-Whitney statistics, $U$ and $U^{\prime}$ are calculated as shown in Equations 3.15 and 3.16 .

$$
\begin{aligned}
& U=n_{1} n_{2}+\frac{n_{1}\left(n_{1}+1\right)}{2}-R_{1} \\
& U^{\prime}=n_{1} n_{2}-U
\end{aligned}
$$

\section{Equation 3.15}

Equation 3.16

where, $\quad \mathrm{n}_{1}=$ number of observations in sample one 


$$
\begin{aligned}
& \mathrm{n}_{2}=\text { number of observations in sample two } \\
& \mathrm{R}_{1}=\text { sum of the ranks of the observations in sample one }
\end{aligned}
$$

In the Mann-Whitney Rank Sum Test, if either $U$ or $U^{\prime}$ is as great as or greater than $U_{\alpha(2), n 1, n 2}$ (obtained from the tables for critical values of the Mann-Whitney $U$ distribution), then the hypothesis $\mathrm{H}_{\mathrm{o}}$ is rejected at the $\alpha$ level of significance and it can be concluded that there is a significant difference between the groups $A$ and $B$. A $95 \%$ level of confidence, $\alpha=0.05$ and $P=0.05$ was used in this test and it is assumed that the hypothesis $\mathrm{H}_{\mathrm{A}}$ is true for $P<0.05$.

\subsubsection{Analysis of Variance (ANOVA)}

The analysis of variance, referred to as $A N O V A$, is used to examine multiple sample populations and determine whether or not differences exist between the multiple populations assuming that the variances for each sample population are the same (Zar 1999). The ANOVA was performed to determine whether or not there were statistical differences between the $\%$ settled sludge, $\%$ total solids and the clarified volume measured after the flocculant additions at different concentrations $(0,20,40,60$ and 120 ppm) for the sludge samples collected before and after primary settling in the dewatering experiments.

In ANOVA, two hypotheses, $\mathrm{H}_{\mathrm{o}}$ and $\mathrm{H}_{\mathrm{A}}$, are considered in a manner similar to the two sample $t$-test. However, $\mathrm{H}_{\mathrm{o}}$ refers to the homogeneity in the variances and $\mathrm{H}_{\mathrm{A}}$ refers to heterogeneity in the variances of the data. If all the samples have equal variances, then an $F$ value is calculated for the samples having $k$ groups and $n$ measurements, as shown in Equations 3.17-3.23 (Zar 1999). 


$$
S S_{w}=\sum_{i=1}^{k}\left[\sum_{j=1}^{n_{i}}\left(X_{i j}-\bar{X}_{i}\right)^{2}\right]
$$

Equation 3.17

where,

$$
\begin{aligned}
& S S_{w}=\text { error sum of squares of deviation for sample population, } i \\
& X_{i j}=\text { measurements in the datum } j \text { of the sample group } i \\
& \bar{X}=\text { population mean } \\
& i=\text { the sample group } \\
& j=\text { the individual datum in the group } i \\
& k=\text { number of groups } \\
& \qquad D F_{w}=\sum_{i=1}^{k}\left(n_{i}-1\right)=N-k
\end{aligned}
$$

where,

$$
\begin{aligned}
& N=\text { total number of data } \\
& D F_{w}=\text { error degrees of freedom } \\
& \quad S S_{a}=\sum_{i=1}^{k} n_{i} \times\left(X_{i}-\bar{X}\right)^{2}
\end{aligned}
$$

where,

$$
\begin{gathered}
S S_{a}=\text { group sum of squares } \\
D F_{a}=k-1
\end{gathered}
$$

where,

$$
\begin{gathered}
D F_{a}=\text { groups degrees of freedom } \\
M S_{w}=\frac{S S_{w}}{D F_{w}}
\end{gathered}
$$

where, 
$M S_{w}$ is the error mean square value

$$
M S_{a}=\frac{S S_{a}}{D F_{a}}
$$

\section{Equation 3.22}

where,

$M S_{a}$ is the group mean square value

$$
F=\frac{M S_{a}}{M S_{w}}
$$

\section{Equation 3.23}

In ANOVA, the hypothesis $\mathrm{H}_{\mathrm{o}}$ is rejected if the calculated $F$ value is at least as large as the critical value $\left(F_{\alpha(1),(\mathrm{k}-1),(\mathrm{N}-1)}\right)\left(\right.$ Zar 1999). $F_{\alpha(1),(\mathrm{k}-1),(\mathrm{N}-1)}$ value is obtained from the tables for critical values of the $F$ distribution at the $\alpha$ significance level. In ANOVA, a $95 \%$ level of confidence, $\alpha=0.05$ and $P=0.05$ was used and it is assumed that the hypothesis $\mathrm{H}_{\mathrm{A}}$ is true for $P<0.05$. However, this test only concludes that all the $k$ population means are significantly different, and not the individual population means (Zar 1999). In order to conclude which of the means are statistically different, a multiple comparision test or a non-parametric Kruskal-Wallis test is performed. If the variances of the data are heterogeneous, the data can be $\log$ transformed to make the variances homogeneous. A non-parametric Kruskal-Wallis test can be performed if the variances are still heterogeneous after log transformation.

\subsubsection{Multiple Comparision}

A multiple comparision test is performed to examine the statistical differences between individual group pairs of means that were concluded to be statistically different as a whole, using the analysis of variance test (Zar 1999). Two hypotheses, $H_{o}$ and $H_{A}$, are considered for all the individual group pairs in the multiple comparision test similar to 
two sample $t$-test. In this test, the means of all the individual groups are ranked and arranged in either an increasing or decreasing order. After ranking the individual groups, pair-wise differences between the ranked means are tabulated and a $q$ value is calculated similar to $t$-value as shown in Equations 3.24 and 3.25.

$$
\begin{gathered}
S E=\sqrt{\frac{M S_{w}}{n}} \\
q=\frac{\bar{X}_{B}-\bar{X}_{A}}{S E}
\end{gathered}
$$

Equation 3.24

Equation 3.25

where,

$M S_{w}$ is the error mean square value from the analysis of variance test $n$ is the number of data in the groups $A$ and $B$

In the multiple comparision test, if the $q \geq q_{\alpha v, k}$ (obtained from the tables for critical values of the $q$ distribution), then the hypothesis Ho is rejected and it can be concluded that there is a significant difference between the groups $A$ and $B$. A $95 \%$ level of confidence, $\alpha=0.05$ and $P=0.05$ was used in this test and it is assumed that the hypothesis $\mathrm{H}_{\mathrm{A}}$ is true for $P<0.05$.

\subsubsection{Non-parametric Kruskal-Wallis Test}

A non-parametric Kruskal-Wallis test is used to non-parametrically determine the difference in multi sample groups due to heterogeneity in the variances in the ANOVA tests (Zar 1999). The Kruskal-Wallis test was performed to determine whether or not there were significant differences between the properties of the sludge affected with time in the aging experiment. However, Kruskal-Wallis test could not be performed on $\mathrm{pH}$ and specific conductance, as only single readings were taken for all storage conditions. 
Kruskal-Wallis test could not be performed to determine the effects of temperature $\left(4^{\circ} \mathrm{C}\right.$ and $20^{\circ} \mathrm{C}$ ) on the sludge properties, as the variances of the sludge properties at both the temperatures were not homogenous.

In this test, the data are ranked from smallest to largest value, and the ranks are summed and arranged in an increasing order of magnitude. Pair wise differences between the ranked sums are tabulated and a $q$ value is calculated as shown in Equations 3.26 and 3.27 .

$$
\begin{aligned}
& S E=\sqrt{\frac{n(n k)(n k+1)}{12}} \\
& q=\frac{R_{B}-R_{A}}{S E}
\end{aligned}
$$

where,

$$
\begin{aligned}
& \mathrm{SE}=\text { standard error between the groups } \\
& \mathrm{R}_{\mathrm{B}}=\text { mean rank of group } \mathrm{B} \\
& \mathrm{R}_{\mathrm{A}}=\text { mean rank of group A } \\
& k=\text { number of groups } \\
& n=\text { number of observations in a group }
\end{aligned}
$$

In the non-parametric Kruskal-Wallis test, if the $q \geq q_{\omega_{*} k}$ (obtained from the tables for critical values of the $q$ distribution), then the hypothesis Ho is rejected and it can be concluded that there is a significant difference between the groups $A$ and $B$. A $95 \%$ level of confidence, $\alpha=0.05$ and $P=0.05$ was used in this test and it is assumed that the hypothesis $\mathrm{H}_{\mathrm{A}}$ is true for $P<0.05$. 


\section{CHAPTER 4: RESULTS}

\subsection{Chemical Analysis of Sludge from the Treatment Site}

The AMD sludge has a high metal content (Fe and Al) and high $\mathrm{pH}$ (Table 4.1). The mean total Fe and Al content were $2526 \pm 2585 \mathrm{mg} / \mathrm{L}$ and $1203 \pm 1209 \mathrm{mg} / \mathrm{L}$ respectively. The sludge also has high content of sulfates $(1338.3 \pm 156 \mathrm{mg} / \mathrm{L})$, ammonia $(466 \pm 147 \mathrm{mg} / \mathrm{L})$ and a low content of $\mathrm{Mn}(19.6 \pm 14.5 \mathrm{mg} / \mathrm{L})$.

Table 4.1: Chemical analysis of sludge from the site.

\begin{tabular}{cc}
\hline Property & Average Value \\
\hline $\mathrm{pH}$ & $8.6 \pm 0.6$ \\
$\begin{array}{c}\text { Specific Conductance } \\
(\mu \mathrm{S} / \mathrm{cm})\end{array}$ & $3534 \pm 399$ \\
Acidity & $140 \pm 1.2$ \\
\% Solids $(\mathrm{g} / \mathrm{g})$ & $1.16 \pm 1.0$ \\
Total Fe $(\mathrm{mg} / \mathrm{L})$ & $2526 \pm 2585$ \\
Total $\mathrm{Al}(\mathrm{mg} / \mathrm{L})$ & $1203 \pm 1209$ \\
Total $\mathrm{Mn}^{(\mathrm{mg} / \mathrm{L})}$ & $19.6 \pm 14.5$ \\
Total $\mathrm{SO}_{4}(\mathrm{mg} / \mathrm{L})$ & $1338.3 \pm 156$ \\
Total $\mathrm{NH}_{3}(\mathrm{mg} / \mathrm{L})$ & $466 \pm 147$ \\
\hline
\end{tabular}

\subsection{Effect of Aging on Sludge Properties}

\subsection{1 pH}

The initial $\mathrm{pH}$ of all the sludge samples ranged between 7.75 and 7.77 (Appendix A, Tables A.1-A.4). The $\mathrm{pH}$ of the sludge samples stored at $20^{\circ} \mathrm{C}$ decreased over time with a greater decrease in the sludge sampled weekly $(12 \%$ for the sludge sampled 
weekly and $6 \%$ for the sludge sampled at longer intervals) (Figure 4.1). The $\mathrm{pH}$ of the sludge samples stored at $4^{\circ} \mathrm{C}$ was virtually unchanged regardless of how frequently they were mixed and sampled.

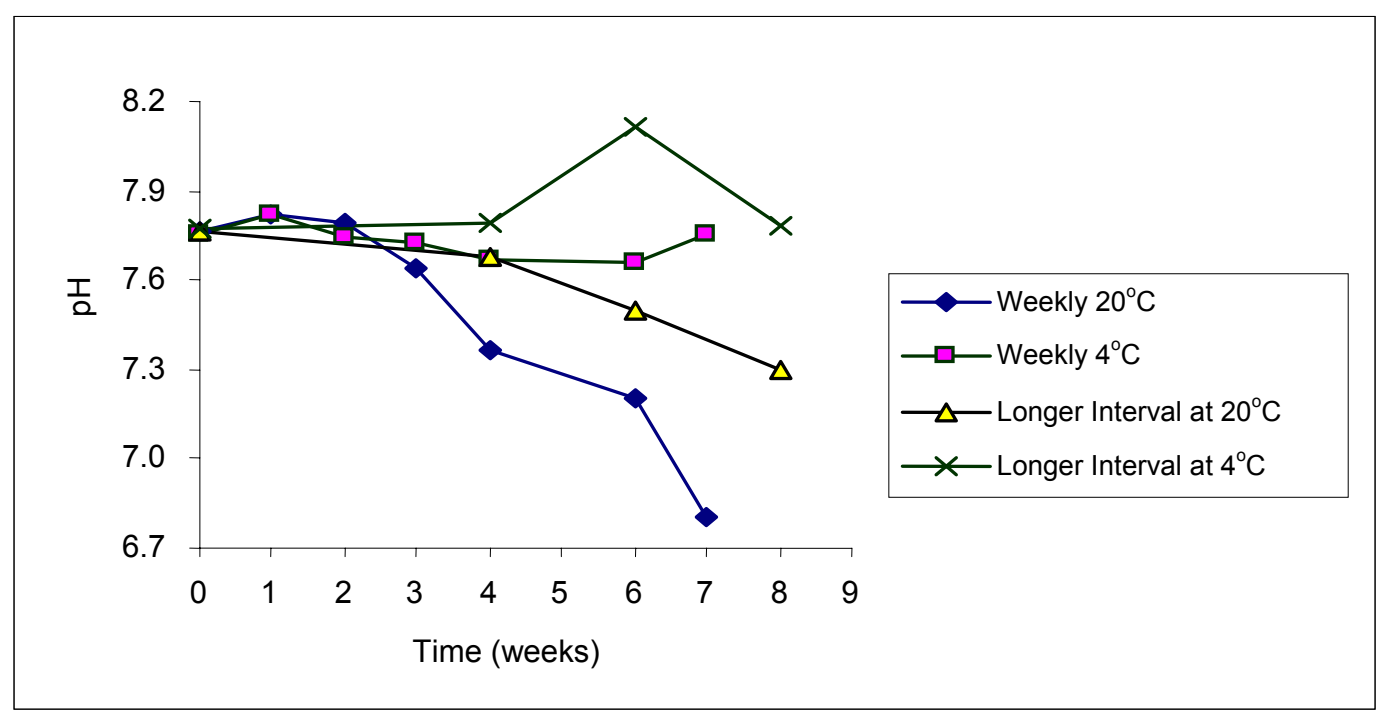

Figure 4.1: Effect of temperature, time and mixing on $\mathrm{pH}$.

\subsubsection{Specific Conductance}

The initial specific conductance of all the sludge samples ranged between 3,996 and 4,009 $\mu \mathrm{S} / \mathrm{cm}$ (Appendix A, Tables A.1-A.4). Under all storage conditions, the specific conductance trended up over time (Figure 4.2). With a decrease in $\mathrm{pH}$ over time for the samples stored at $20^{\circ} \mathrm{C}$, specific conductance would be expected to decrease. However, when compared with the order of magnitude of measurements, the increase was minor $(0.1-1.3 \%$ for the sludge sampled weekly and $0.2-0.7 \%$ for the sludge sampled at longer intervals). 


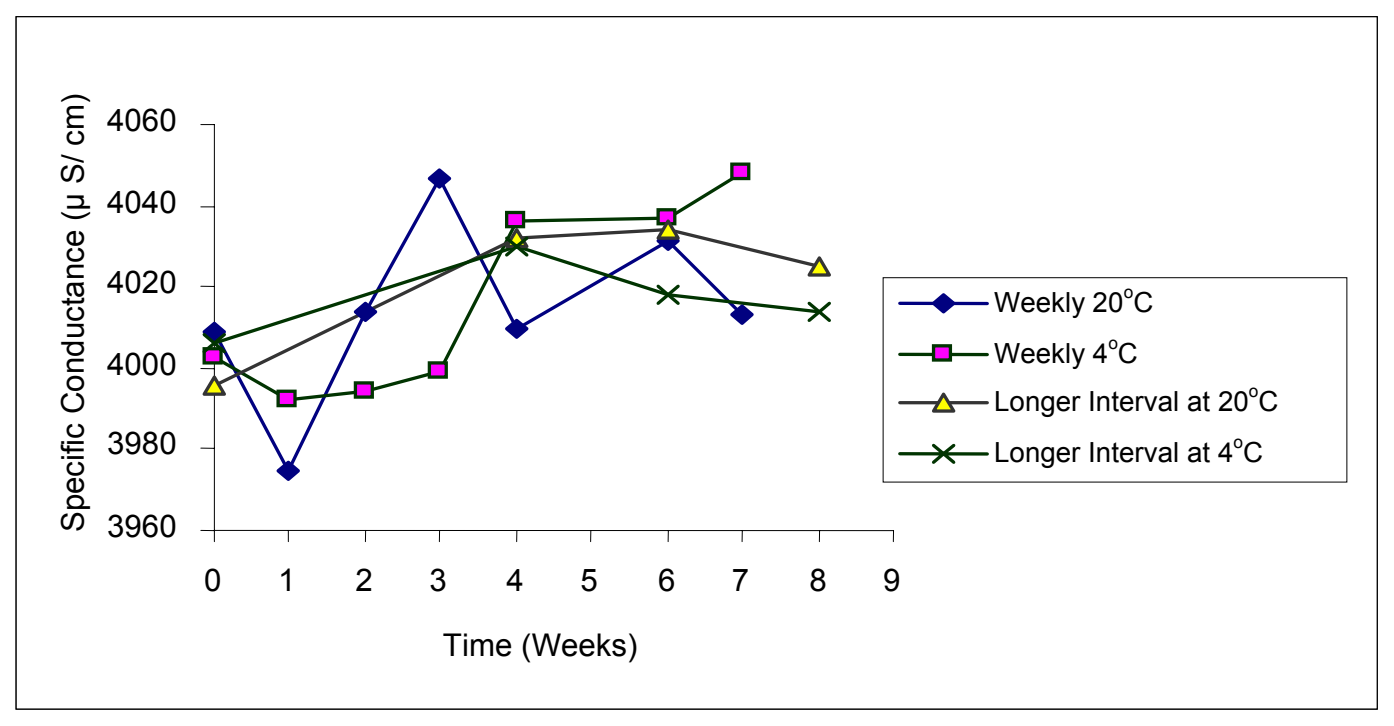

Figure 4.2: Effect of temperature, time and mixing on specific conductance.

\subsubsection{Percent Settled Sludge (PSS)}

Under all storage conditions, PSS decreased over time with a greater decrease observed in the sludge sampled weekly (Figure 4.3) (Appendix A, Tables A.1-A.4). When stored at $20^{\circ} \mathrm{C}$, there was a significant difference between PSS at week 1 and at week 4 (Kruskal-Wallis, $\mathrm{p}=0.018$ and Appendix C, Table C.1) but between no other groups. When stored at $4^{\circ} \mathrm{C}$, PSS was significantly lower at weeks 6 and 7 than at week 1 (Kruskal-Wallis, $\mathrm{p}=0.007$ and Appendix C, Table C.4).

The PSS decreased in the range of 4-8\% for the sludge sampled weekly and in the range of $0.6-4 \%$ for the sludge sampled at longer intervals. PSS stored at both temperatures was greater in sludge that was mixed at longer intervals. Differences were significant at weeks 4 and 6 for sludge stored at $20^{\circ} \mathrm{C}$ ( $t$-test, $\left.\mathrm{p}<0.001\right)$ and at week 6 for sludge stored at $4^{\circ} \mathrm{C}$. The initial percent settled sludge of all the sludge samples was not measured. However, the changes in percent settled sludge were small enough to not affect any practical application. 


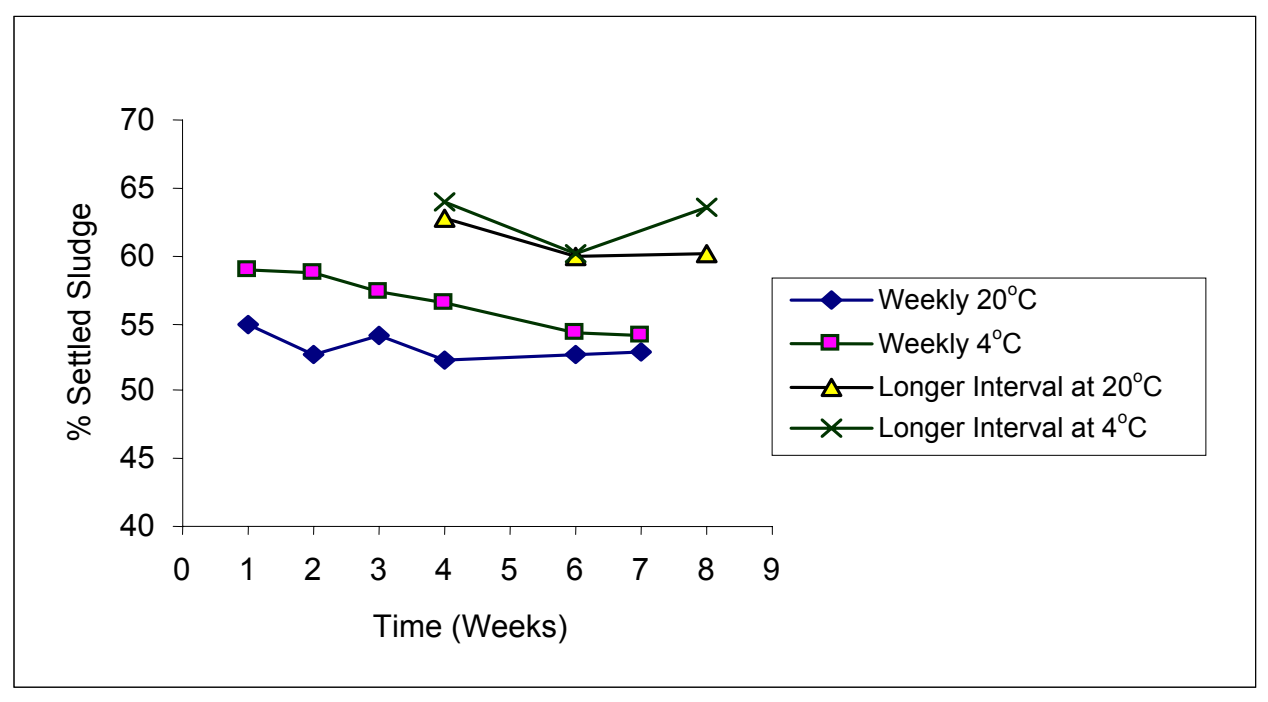

Figure 4.3: Effect of temperature, time and mixing on percent settled sludge.

\subsubsection{Viscosity}

The initial viscosity of all the sludge samples ranged between 9.4 and $9.9 \mathrm{cP}$ (Appendix A, Tables A.1-A.4). In all samples, shear stress increased linearly with an increase in the shear rate. Consequently the samples under investigation behaved as Newtonian fluids. The viscosity of the sludge sampled weekly decreased over time and the viscosity of the sludge sampled at longer intervals increased over time (Figure 4.4). However, the changes in these properties were so minor as to not affect any practical application. 


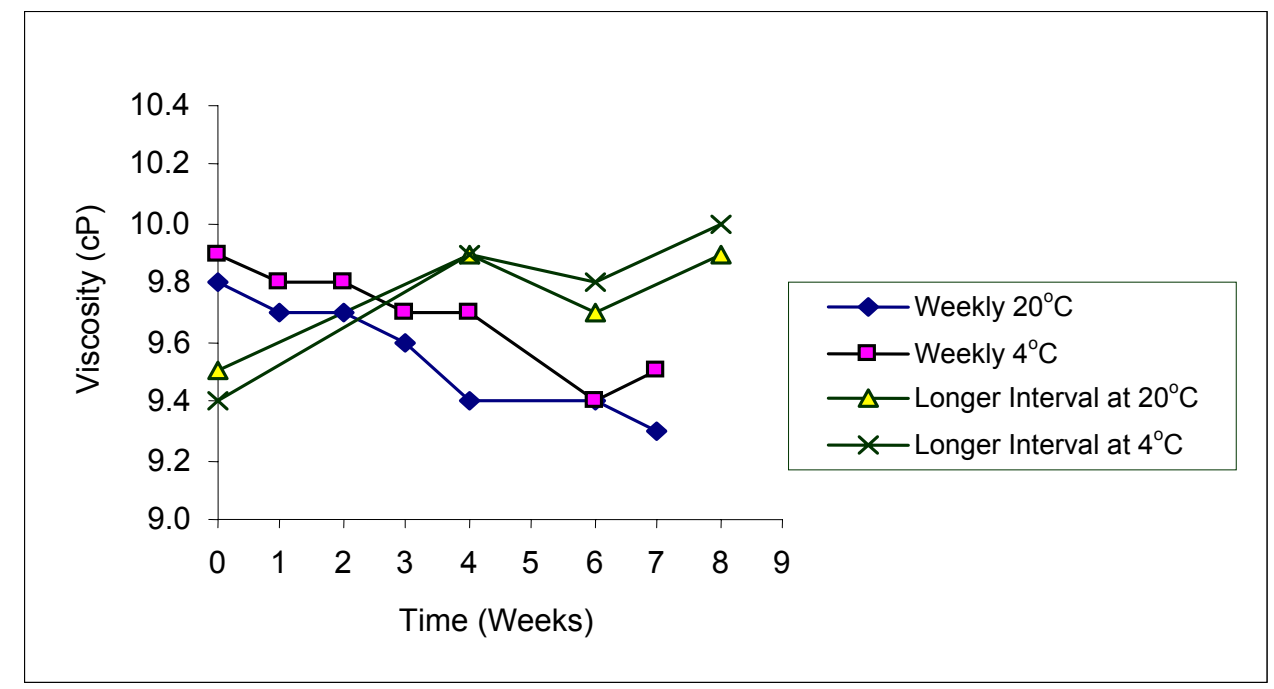

Figure 4.4: Effect of temperature, time and mixing on viscosity.

\subsubsection{Specific Resistance to Filtration (SRF)}

The SRF of the sludge sampled weekly decreased slightly over time with a greater decrease in SRF for the sludge stored at $4^{\circ} \mathrm{C}\left(31 \%\right.$ for $4^{\circ} \mathrm{C}$ and $19 \%$ for $\left.20^{\circ} \mathrm{C}\right)$ (Appendix A, Tables A.1-A.4). The SRF of the sludge sampled at longer intervals decreased for the sludge stored at $4^{\circ} \mathrm{C}(19 \%)$ and increased slightly for the sludge stored at $20^{\circ} \mathrm{C}(1 \%)$ (Figure 4.5). The initial specific resistance to filtration (SRF) of all the sludge samples was not measured as the procedure for SRF measurement was not yet evaluated during initial characterization. However, when compared with the order of magnitude of measurements, the changes in SRF were so minute that they will not affect any practical application. 


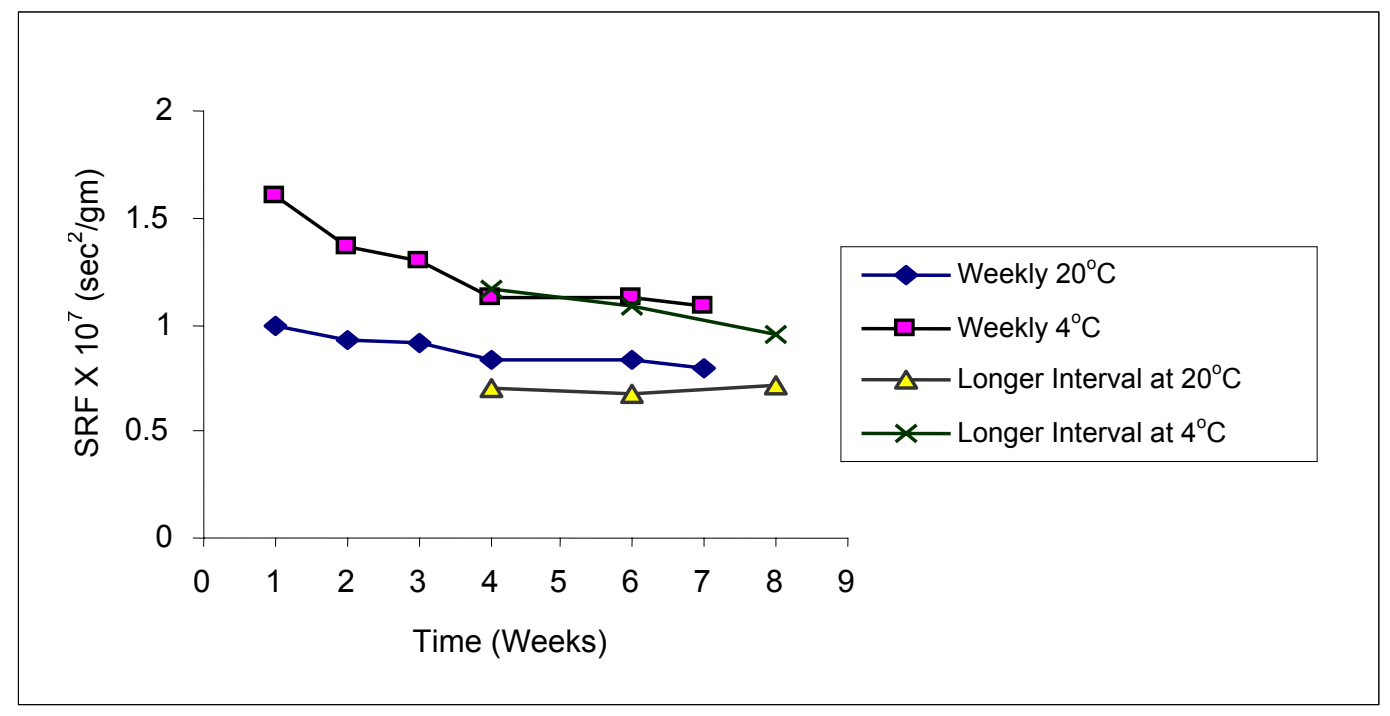

Figure 4.5: Effect of temperature, time and mixing on SRF.

\subsubsection{Particle Size Distribution}

The initial mean particle size of all the sludge samples was in the range of 11.79014.100 $\mu \mathrm{m}$ (Appendix A, Tables A.1-A.4). The initial modal value of all the sludge samples ranged from 10.290-11.290 $\mu \mathrm{m}$ (Appendix A, Tables A.1-A.4). Both the mean and mode of particle size of the samples under all storage conditions decreased slightly over time. Despite starting at approximately the same value, both the mean and mode decreased by $2-3 \mu \mathrm{m}$ for sludge sampled weekly and decreased by $1 \mu \mathrm{m}$ or less for sludge sampled at longer intervals (Figures 4.6 and 4.7). The decrease in mean and mode of particle size for the sludge sampled weekly was greater in the first week with little or no change after the first week, whereas the decrease in mean and mode of particle size for the sludge sampled at longer intervals of time was more gradual.

When stored at $20^{\circ} \mathrm{C}$, mean particle size was significantly lower at week 4 than at week 1; differences between other weeks were not significant (Kruskal-Wallis, $\mathrm{p}=0.027$ and Appendix C, Table C.2). When stored at $4^{\circ} \mathrm{C}$, mean particle size was significantly 
lower at week 7 than at week 1; differences between other weeks were not significant (Kruskal-Wallis, $\mathrm{p}=0.016$ and Appendix C, Table C.5). When stored at both $20^{\circ} \mathrm{C}$ and $4^{\circ} \mathrm{C}$, mode of particle size was not significantly different between any of the weeks (Kruskal-Wallis, $\mathrm{p}=0.055$ for $4^{\circ} \mathrm{C}$ and $\mathrm{p}=0.06$ for $20^{\circ} \mathrm{C}$ and Appendix C, Tables C. 3 and C.6).

When stored at $20^{\circ} \mathrm{C}$, the mean particle size was significantly greater for the sludge mixed less frequently at both 4 and 6 weeks $(t$-test, $\mathrm{p}<0.001)$. When stored at $4^{\circ} \mathrm{C}$, there was no significant difference between samples mixed weekly and those mixed at longer intervals at week 4 (Mann-Whitney, $\mathrm{p}=0.10)$. However, differences in mean particle size were significant at week $6(t$-test, $\mathrm{p}<0.001)$. When stored at $4^{\circ} \mathrm{C}$, the mode of particle size was not significant for the sludge mixed less frequently at week 4 (MannWhitney, $\mathrm{p}=0.10$ ). The differences in mode of particle size were significantly greater at week 6 ( $t$-test, $\mathrm{p}<0.001)$. However, the changes in mean and mode of particle size were so minor that they will not affect any practical application.

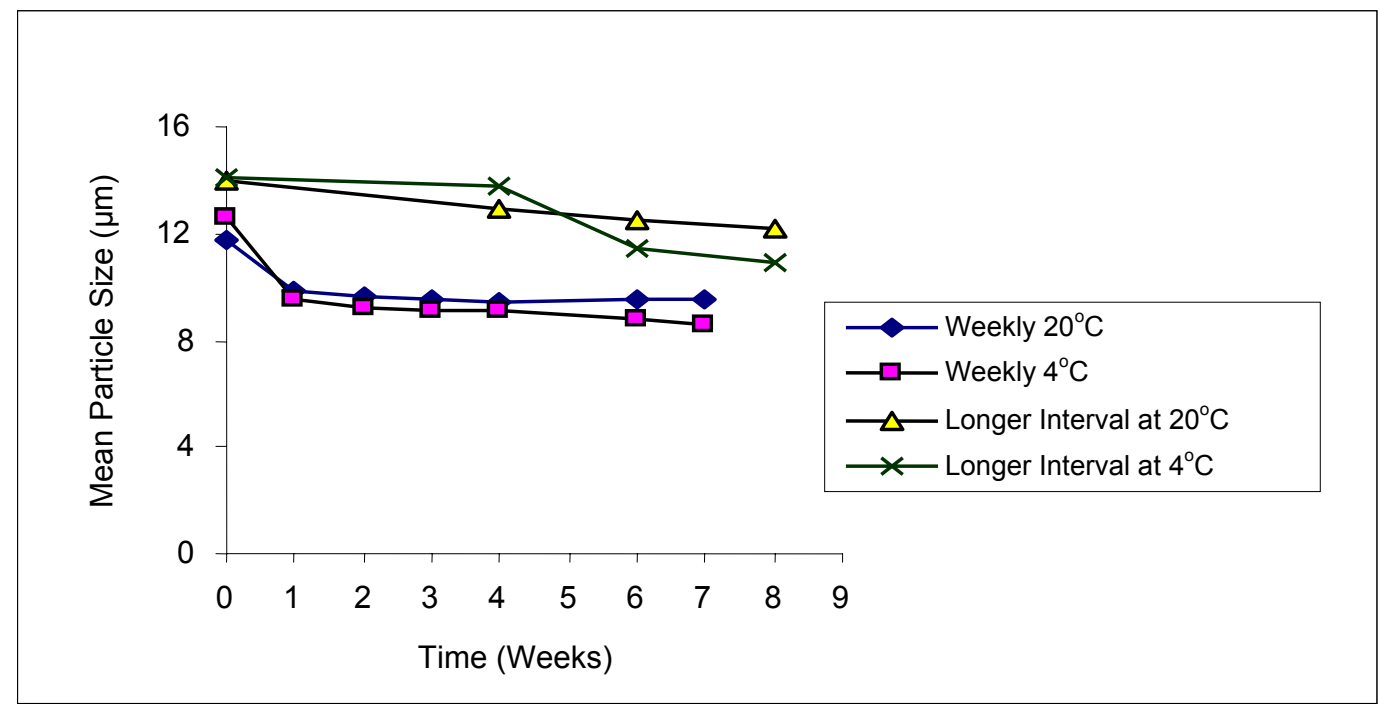

Figure 4.6: Effect of temperature, time and mixing on mean particle size. 


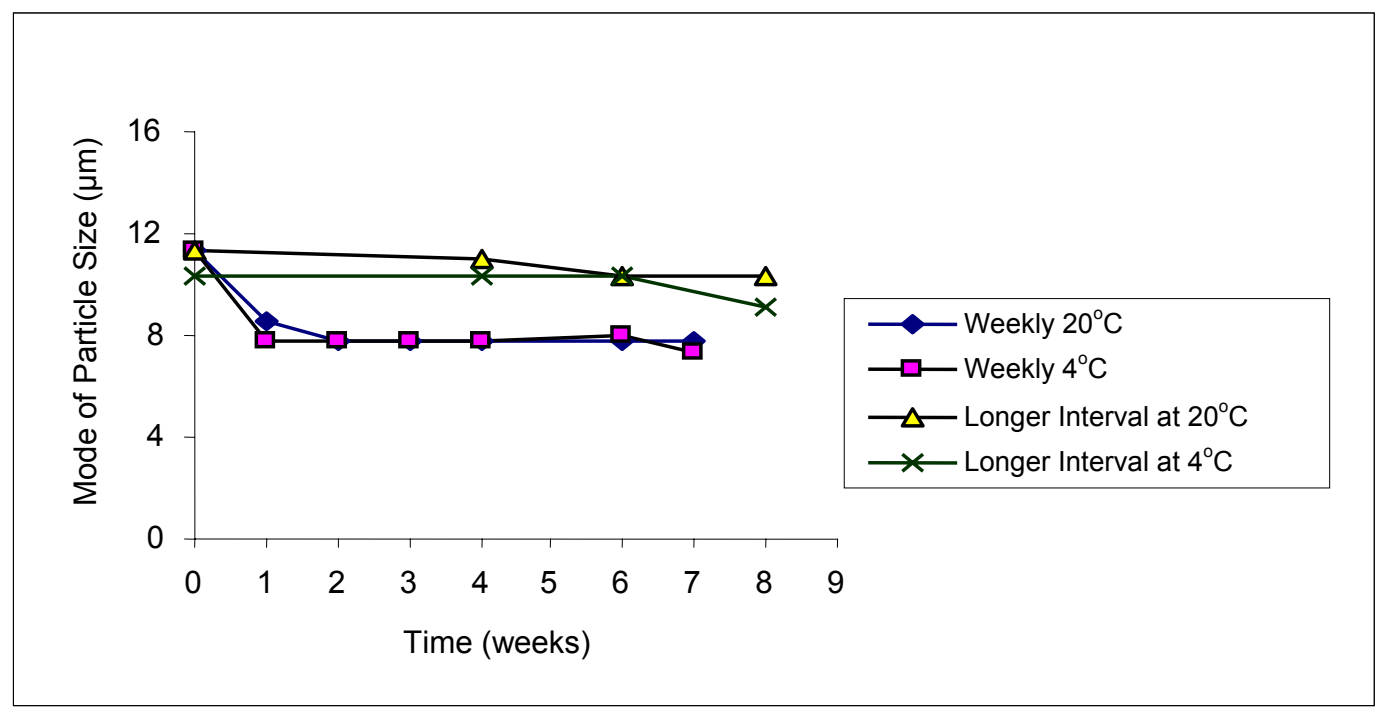

Figure 4.7: Effect of temperature, time and mixing on mode of particle size.

\subsection{Effect of Dewatering Treatment Methods}

\subsubsection{Comparision of Sludge Characteristics}

The properties of the sludge collected before and after primary settling remained fairly consistent, as represented in Table 4.1 (Appendix B, Tables B.1 and B.4). No significant differences in $\mathrm{pH}$ or specific conductance between sludge samples collected before and after primary settling were observed. Viscosity, percent settled sludge, \% solids and specific resistance to filtration were significantly greater in the sludge samples collected after primary settling (Table 4.1). The viscosity and specific resistance to filtration (SRF) gradually increased as the \% initial total solids increased in the sludge samples collected after primary settling (Appendix B, Table B.4). In all samples, shear stress increased linearly with an increase in the shear rate similar to the samples in the aging experiment. Consequently the samples under investigation behaved as Newtonian fluids. 
Table 4.2: Properties of the sludge collected before and after primary settling.

\begin{tabular}{|c|c|c|c|}
\hline Property & $\begin{array}{l}\text { Sludge Collected } \\
\text { Before Primary } \\
\text { Settling } \\
\text { Mean } \pm \text { Std. Dev } \\
\text { (Range) } \\
\end{array}$ & $\begin{array}{l}\text { Sludge Collected } \\
\text { After Primary } \\
\text { Settling } \\
\text { Mean } \pm \text { Std. Dev } \\
\text { (Range) } \\
\end{array}$ & $\begin{array}{c}\text { Two Sample t-test } \\
\begin{array}{c}\text { p-value/significant } \\
\text { difference* }\end{array}\end{array}$ \\
\hline $\mathrm{pH}$ & $\begin{array}{c}9.1 \pm 0.3 \\
(8.67-9.34)\end{array}$ & $\begin{array}{c}9.09 \pm 0.1 \\
(8.96-9.23)\end{array}$ & 0.988 / No \\
\hline $\begin{array}{c}\text { Specific } \\
\text { Conductance } \\
(\mu \mathrm{S} / \mathrm{cm})\end{array}$ & $\begin{array}{c}3,700 \pm 179 \\
(3,488-3,889)\end{array}$ & $\begin{array}{c}3,505 \pm 376 \\
(3,164-3,966)\end{array}$ & 0.384 / No \\
\hline Viscosity ( cP ) & $\begin{array}{c}8.7 \pm 0.1 \\
(8.6-8.8)\end{array}$ & $\begin{array}{c}11.7 \pm 1.1 \\
(10.5-13.1)\end{array}$ & $0.002 /$ Yes \\
\hline$\%$ Settled Sludge & $\begin{array}{c}21.8 \pm 0.2 \\
(21.5-22.1)\end{array}$ & $\begin{array}{c}76.4 \pm 10.4 \\
(62.8-87.8)\end{array}$ & $0.000 /$ Yes \\
\hline $\begin{array}{l}\text { \% Total Solids } \\
(\mathrm{g} / \mathrm{g})\end{array}$ & $\begin{array}{c}0.19 \pm 0.03 \\
(0.17-0.24)\end{array}$ & $\begin{array}{c}0.84 \pm 0.30 \\
(0.47-1.13)\end{array}$ & 0.023 / Yes \\
\hline $\begin{array}{l}\text { S.R.F x } 10^{7} \\
\left(\mathrm{sec}^{2} / \mathrm{gm}\right)\end{array}$ & $\begin{array}{c}1.74 \pm 0.79 \\
(1.26-2.92)\end{array}$ & $\begin{array}{c}4.43 \pm 0.80 \\
(3.80-5.60)\end{array}$ & 0.003 / Yes \\
\hline $\begin{array}{l}\text { Pumping Rate } \\
(\text { gpm })\end{array}$ & $\begin{array}{c}97 \pm 9 \\
(90-108)\end{array}$ & N.A. & N.A. \\
\hline
\end{tabular}

* For $p>0.05$, there was no statistically significant difference between properties of the sludge samples collected before and after primary settling (Zar 1999).

\subsubsection{Vacuum Filtration}

\subsubsection{Sludge Collected Before Primary Settling}

The $\%$ total solids obtained from vacuum filtration ranged from $8.32-9.66 \mathrm{~g} / \mathrm{g}$ and approximately $174 \mathrm{ml}$ of filtrate from a total of $180 \mathrm{ml}$ was obtained (Appendix B, Tables B.2 and B.3). The efficiency ranged between $96-97 \%$ and the concentration factor ranged from 38 to 52 for all the samples (Figures 4.8 and 4.9). The average values of $\%$ final solids, volume of water removed, efficiency and concentration factor for the four sludge samples collected before primary settling are given in Table 4.2. 
Table 4.3: Summary of dewatering methods applied on sludge collected before primary settling. Initial \% solids were $0.19 \pm 0.03 \mathrm{~g} / \mathrm{g}$.

\begin{tabular}{|c|c|c|c|c|c|}
\hline Dewatering Method & & $\begin{array}{c}\text { \% Final } \\
\text { Total } \\
\text { Solids* }(g / g) \\
\end{array}$ & $\begin{array}{c}\text { Volume of } \\
\text { Water } \\
\text { Removed* }(\mathrm{ml}) \\
\end{array}$ & Efficiency* & $\begin{array}{l}\text { Conc. } \\
\text { Factor* }\end{array}$ \\
\hline Vacuum Filtration & & $9.12 \pm 0.6$ & $174 \pm 1$ & $96.8 \pm 0.5$ & $48.3 \pm 8.2$ \\
\hline Pressure Filtration & & $\mathrm{F}$ & $\mathrm{F}$ & $\mathrm{F}$ & $\mathrm{F}$ \\
\hline \multicolumn{6}{|l|}{ Flocculants } \\
\hline \multirow{5}{*}{ Calloway 4910} & $0 \mathrm{ppm}$ & $0.55 \pm 0.06$ & $393 \pm 5$ & $78.5 \pm 1.0$ & $2.9 \pm 0.5$ \\
\hline & $20 \mathrm{ppm}$ & $0.50 \pm 0.08$ & $396 \pm 3$ & $79.0 \pm 0.8$ & $2.6 \pm 0.4$ \\
\hline & 40 ppm & $0.48 \pm 0.05$ & $395 \pm 4$ & $79.0 \pm 0.8$ & $2.5 \pm 0.4$ \\
\hline & $60 \mathrm{ppm}$ & $0.57 \pm 0.18$ & $409 \pm 11$ & $81.8 \pm 2.2$ & $3.1 \pm 1.1$ \\
\hline & $120 \mathrm{ppm}$ & $2.02 \pm 0.16$ & $458 \pm 6$ & $91.5 \pm 1.3$ & $10.7 \pm 1.9$ \\
\hline \multirow{5}{*}{ Alco Clear ACP } & $0 \mathrm{ppm}$ & $0.57 \pm 0.13$ & $394 \pm 6$ & $78.8 \pm 1.3$ & $3.0 \pm 0.7$ \\
\hline & 20 ppm & $0.49 \pm 0.04$ & $381 \pm 7$ & $76.3 \pm 1.3$ & $2.6 \pm 0.4$ \\
\hline & $40 \mathrm{ppm}$ & $0.48 \pm 0.07$ & $375 \pm 6$ & $75.0 \pm 1.2$ & $2.6 \pm 0.6$ \\
\hline & 60 ppm & $0.45 \pm 0.05$ & $375 \pm 6$ & $75.0 \pm 1.2$ & $2.4 \pm 0.4$ \\
\hline & $120 \mathrm{ppm}$ & $0.47 \pm 0.07$ & $371 \pm 17$ & $74.3 \pm 3.4$ & $2.5 \pm 0.3$ \\
\hline \multirow{5}{*}{ Acco-Phos 1250} & 0 ppm & $0.58 \pm 0.06$ & $401 \pm 7$ & $80.3 \pm 1.3$ & $3.1 \pm 0.4$ \\
\hline & 20 ppm & $0.55 \pm 0.07$ & $402 \pm 9$ & $80.5 \pm 1.7$ & $2.9 \pm 0.5$ \\
\hline & 40 ppm & $0.46 \pm 0.10$ & $397 \pm 7$ & $79.5 \pm 1.3$ & $2.5 \pm 0.8$ \\
\hline & $60 \mathrm{ppm}$ & $0.72 \pm 0.25$ & $421 \pm 13$ & $84.3 \pm 2.6$ & $3.8 \pm 1.5$ \\
\hline & 120 ppm & $2.48 \pm 0.23$ & $461 \pm 5$ & $92.3 \pm 1.0$ & $13.1 \pm 2.7$ \\
\hline
\end{tabular}

F: Pressure filtration failed on the sludge collected before primary settling.

* Average values of the four sludge samples collected before primary settling. 


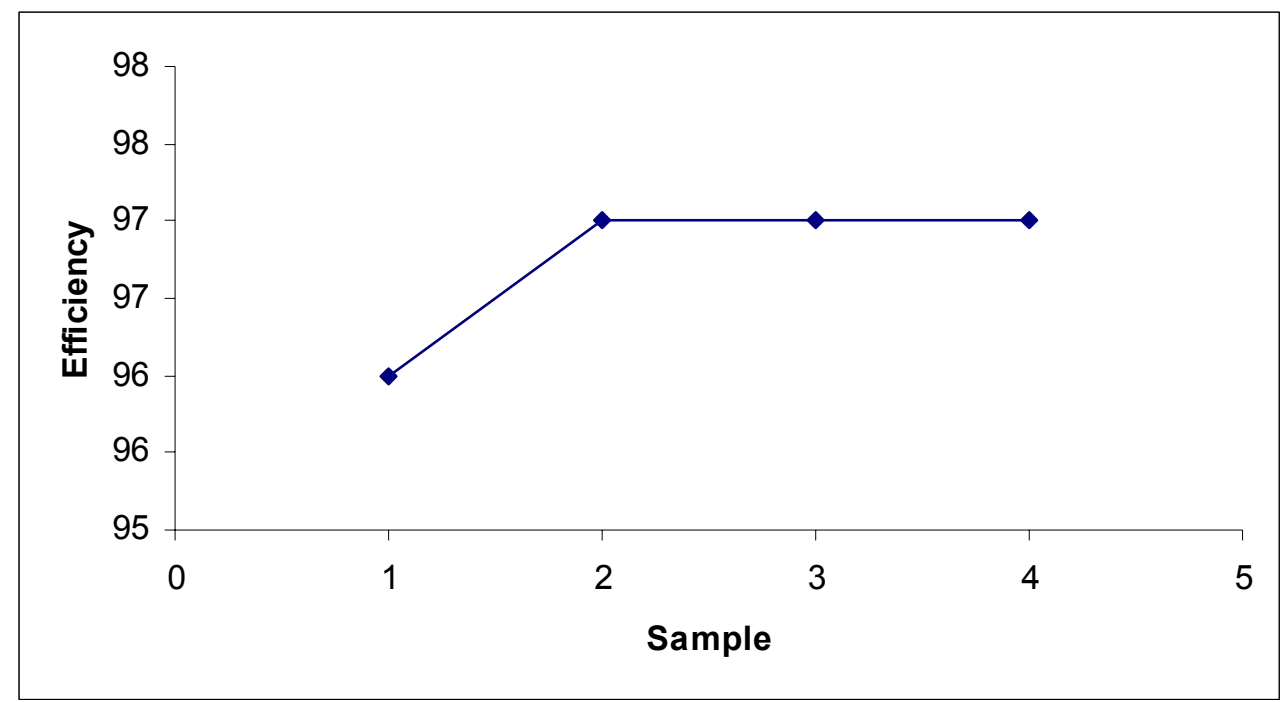

Figure 4.8: Efficiency of vacuum filtration applied on sludge collected before primary settling.

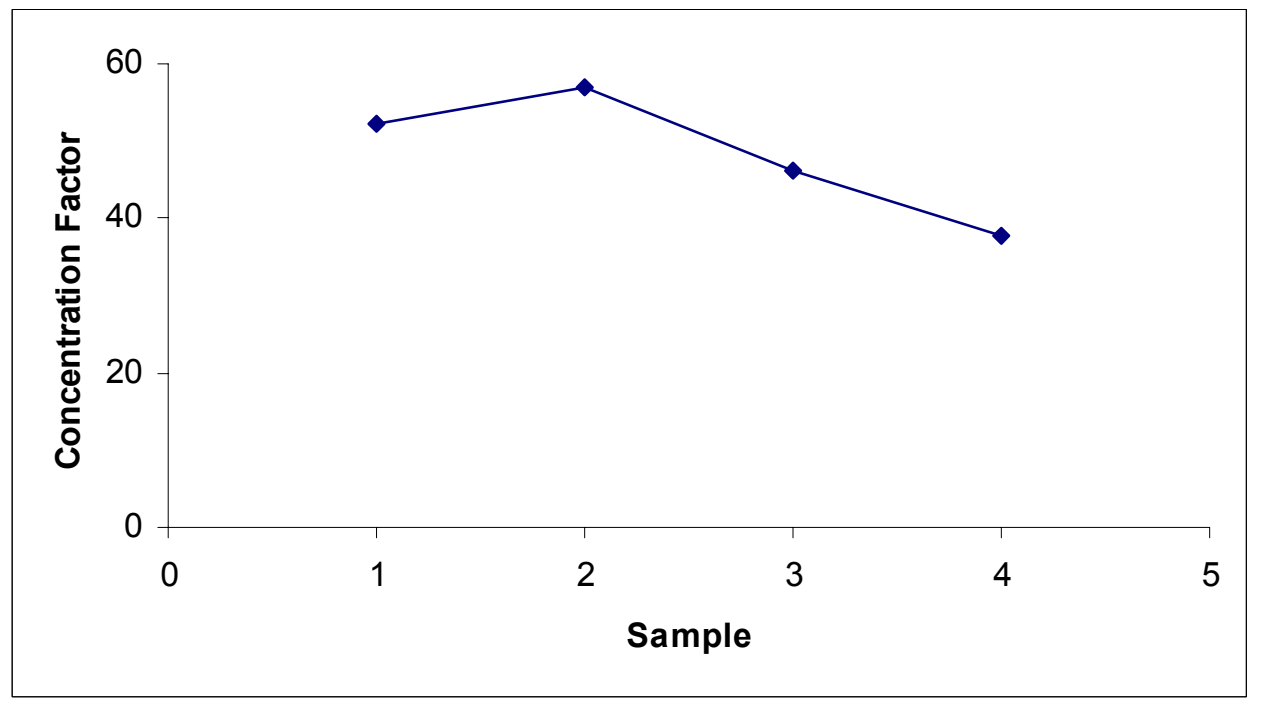

Figure 4.9: Concentration factor for vacuum filtration applied on sludge collected before primary settling.

It took approximately 3 minutes for the sludge samples to dewater by vacuum filtration with the exception of the first sample, which took approximately 7 minutes. During vacuum filtration, a thin film of cake was formed on the filter paper. The filtrate was not completely clear, indicating that the sludge had particles with size $<8 \mu \mathrm{m}$, which 
the filter paper was not able to hold and that vacuum filtration did not completely remove the precipitates.

\subsubsection{Sludge Collected After Primary Settling}

The $\%$ total solids obtained from vacuum filtration ranged from $6.08-7.65 \mathrm{~g} / \mathrm{g}$ and approximately $164 \mathrm{ml}$ of the filtrate volume was obtained (Appendix B, Tables B.5 and B.6). The efficiency ranged between $86-95 \%$ with a concentration factor between 6-13 for all the sludge samples (Figures 4.10 and 4.11). The average values of $\%$ final solids, volume of water removed, efficiency and concentration factor for the four sludge samples collected after primary settling are given in Table 4.3.

The total time to dewater the sludge samples using vacuum filtration increased

linearly $\left(\mathrm{R}^{2}=0.9067\right)$ as the $\%$ initial total solids in the sludge sample increased (Figure 4.12). It took approximately 11 minutes to dewater the sludge sample with $\%$ initial total solids of $0.47 \mathrm{~g} / \mathrm{g}$ and approximately 20 minutes for the sludge sample with \% initial total solids of $1.13 \mathrm{~g} / \mathrm{g}$. 
Table 4.4: Summary of dewatering methods applied on sludge collected after primary settling. Initial \% solids were $0.84 \pm 0.30 \mathrm{~g} / \mathrm{g}$.

\begin{tabular}{cccccc}
\hline Dewatering Method & & $\begin{array}{c}\text { \% Final } \\
\text { Total } \\
\text { Solids*(g/g) }\end{array}$ & $\begin{array}{c}\text { Volume of } \\
\text { Water } \\
\text { Removed*(ml) }\end{array}$ & Efficiency* & $\begin{array}{c}\text { Conc. } \\
\text { Factor* }\end{array}$ \\
\hline Vacuum Filtration & & $6.72 \pm 0.66$ & $164 \pm 7$ & $91.0 \pm 3.7$ & $8.8 \pm 3.0$ \\
$\begin{array}{c}\text { Pressure Filtration } \\
\text { Flocculants }\end{array}$ & & $9.88 \pm 0.29$ & $166 \pm 5$ & $92.0 \pm 2.6$ & $13.4 \pm 5.9$ \\
& $0 \mathrm{ppm}$ & $1.13 \pm 0.34$ & $113 \pm 55$ & $22.8 \pm 11.2$ & $1.4 \pm 0.3$ \\
& $20 \mathrm{ppm}$ & $1.12 \pm 0.24$ & $112 \pm 55$ & $22.5 \pm 11.3$ & $1.4 \pm 0.4$ \\
Calloway 4910 & $40 \mathrm{ppm}$ & $1.13 \pm 0.24$ & $111 \pm 57$ & $22.3 \pm 11.2$ & $1.5 \pm 0.4$ \\
& $60 \mathrm{ppm}$ & $1.12 \pm 0.25$ & $110 \pm 61$ & $22.0 \pm 12.4$ & $1.4 \pm 0.3$ \\
& $120 \mathrm{ppm}$ & $1.09 \pm 0.23$ & $136 \pm 70$ & $27.0 \pm 14.4$ & $1.4 \pm 0.3$ \\
& & & & & \\
Alco Clear ACP & & & & & \\
& $20 \mathrm{ppm}$ & $1.12 \pm 0.25$ & $116 \pm 55$ & $23.0 \pm 10.8$ & $1.4 \pm 0.3$ \\
& $60 \mathrm{ppm}$ & $1.09 \pm 0.25$ & $114 \pm 56$ & $22.8 \pm 11.2$ & $1.4 \pm 0.3$ \\
& $120 \mathrm{ppm}$ & $1.07 \pm 0.23$ & $109 \pm 58$ & $21.5 \pm 11.6$ & $1.4 \pm 0.3$ \\
& & $1.08 \pm 0.21$ & $104 \pm 63$ & $20.8 \pm 12.8$ & $1.4 \pm 0.3$ \\
& & & & & \\
\hline & $0 \mathrm{ppm}$ & $1.10 \pm 0.26$ & $115 \pm 55$ & $23.0 \pm 10.8$ & $1.4 \pm 0.3$ \\
& $20 \mathrm{ppm}$ & $1.08 \pm 0.32$ & $114 \pm 59$ & $22.8 \pm 12.0$ & $1.3 \pm 0.2$ \\
& $40 \mathrm{ppm}$ & $1.12 \pm 0.27$ & $112 \pm 57$ & $22.5 \pm 11.3$ & $1.4 \pm 0.3$ \\
& $60 \mathrm{ppm}$ & $1.11 \pm 0.25$ & $109 \pm 62$ & $21.8 \pm 12.5$ & $1.4 \pm 0.3$ \\
& $120 \mathrm{ppm}$ & $1.09 \pm 0.22$ & $102 \pm 68$ & $20.3 \pm 13.6$ & $1.4 \pm 0.4$ \\
\hline
\end{tabular}

* Average values of the four sludge samples collected after primary settling. 


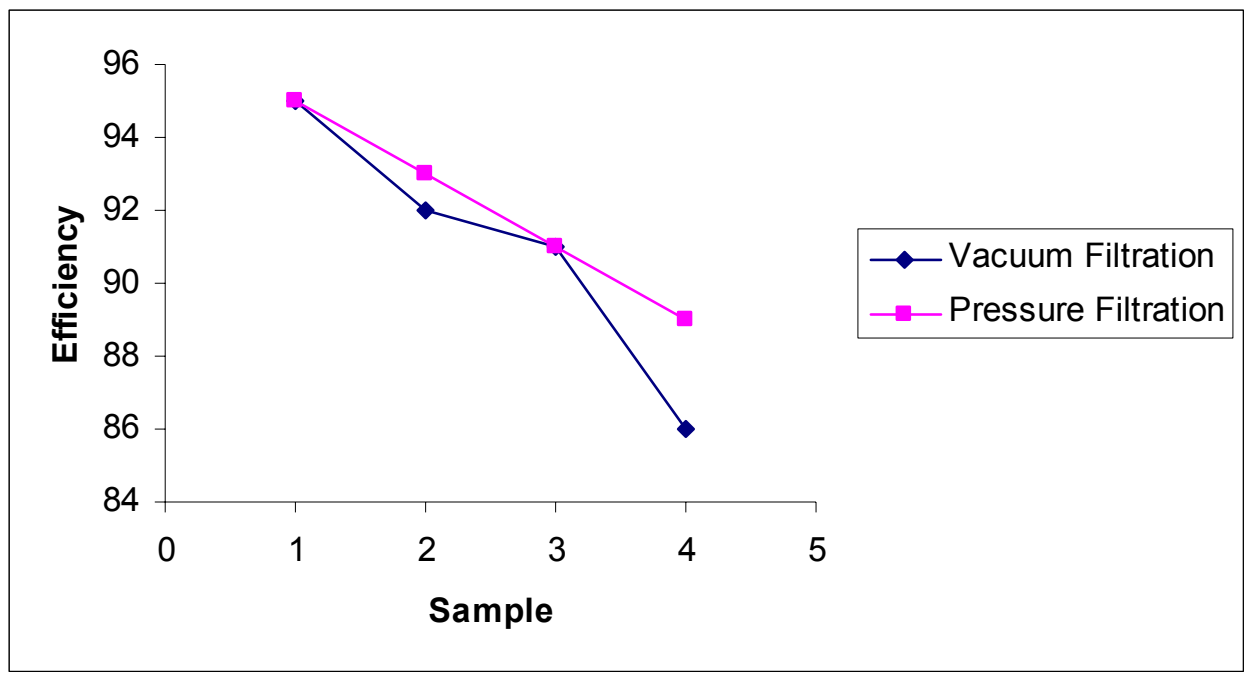

Figure 4.10: Efficiency of vacuum filtration and pressure filtration applied on sludge collected after primary settling.

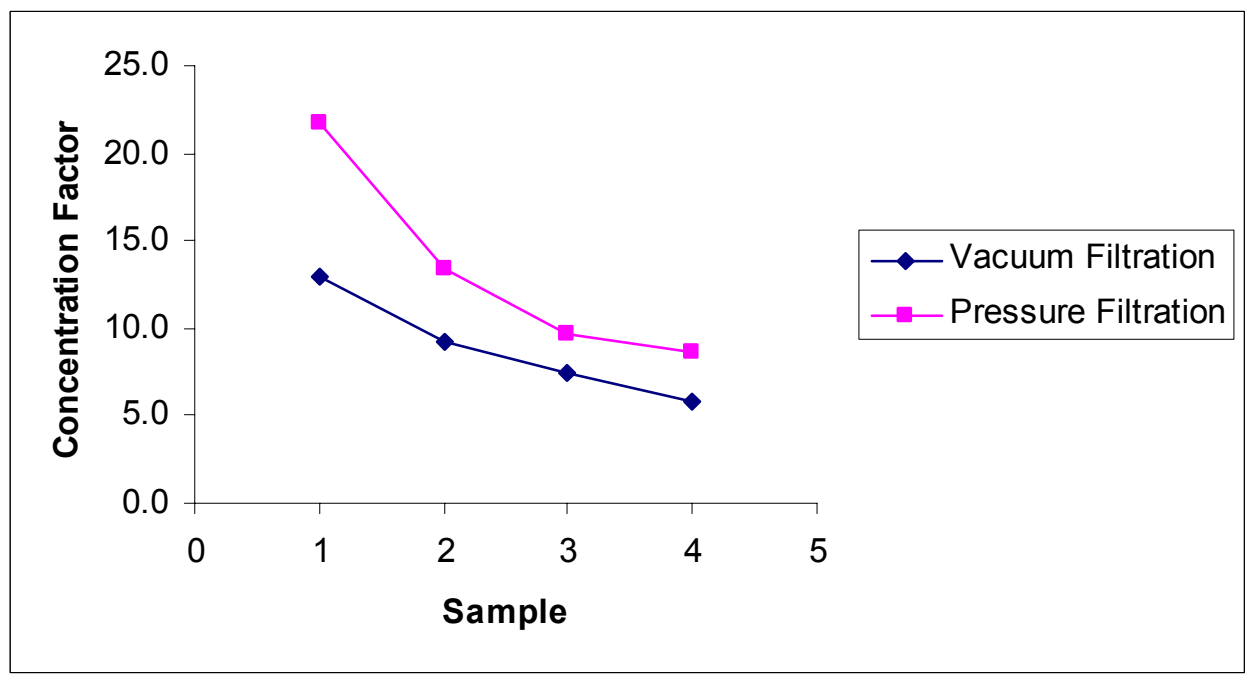

Figure 4.11: Concentration factor for vacuum filtration and pressure filtration applied on sludge collected after primary settling. 


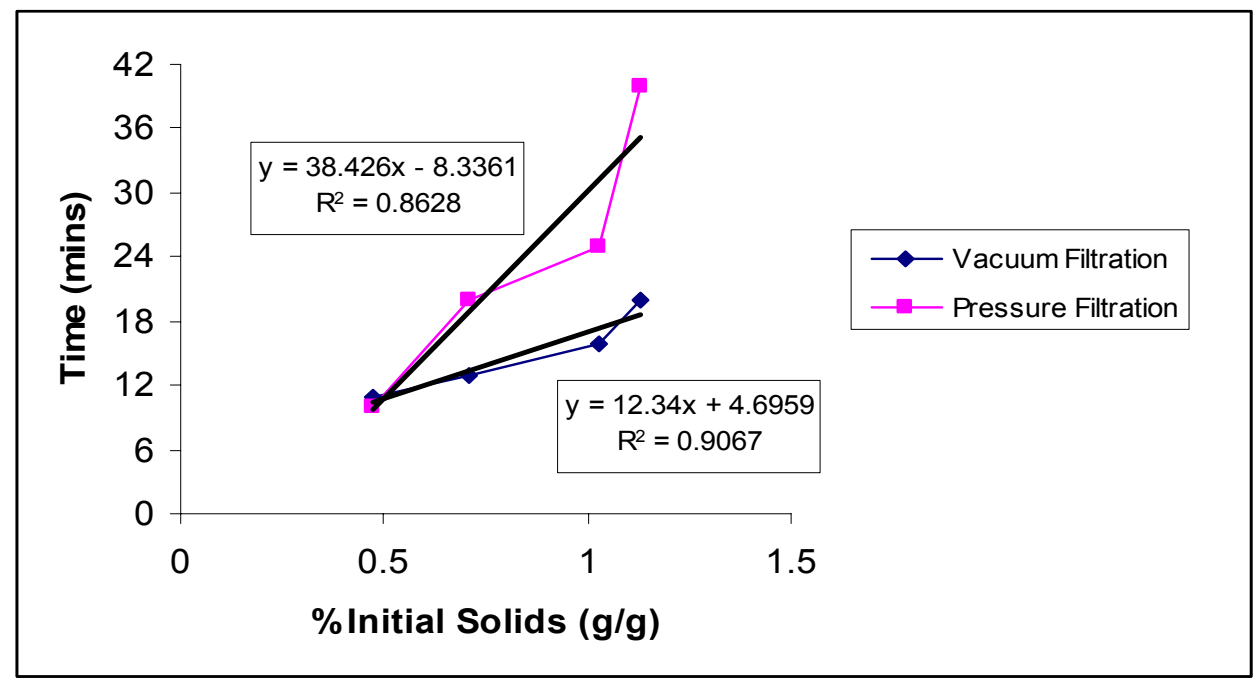

Figure 4.12: Dewatering time by vacuum filtration and pressure filtration applied on sludge collected after primary settling.

\subsubsection{Pressure Filtration}

\subsubsection{Sludge Collected Before Primary Settling}

Pressure filtration failed to dewater all the sludge samples. The filter paper was able to hold the solids before the application of pressure. However, after pressure was applied, the entire sample, including solids passed through the filter paper in 3-5 seconds.

\subsubsection{Sludge Collected After Primary Settling}

The $\%$ total solids obtained from pressure filtration ranged from 9.54-10.21 g/g and approximately $166 \mathrm{ml}$ of the filtrate volume was obtained (Appendix B, Tables B.5 and B.6). The efficiency ranged between $89-95 \%$ and the concentration factor between 922 for all the sludge samples (Table 4.3, Figures 4.10 and 4.11). The total time to dewater the sludge samples using pressure filtration increased approximately linearly $\left(\mathrm{R}^{2}=0.8628\right)$ as the $\%$ initial total solids in the sludge samples increased (Figure 4.12). It took approximately 10 minutes to dewater the sludge sample with \% initial total solids of 0.47 
$\mathrm{g} / \mathrm{g}$ and approximately 40 minutes for the sludge sample with \% initial total solids of 1.13 $\mathrm{g} / \mathrm{g}$.

\subsubsection{Flocculant Addition}

\subsubsection{Sludge Collected Before Primary Settling}

The floc in the control (0 ppm flocculant concentration) settled quickly. The settling height after 3 hours was only $0.3 \mathrm{~cm}$ greater than the settling height after 24 hours. The settling rate increased with flocculant addition and further increased as the flocculant concentration increased. For controls, the \% settled sludge ranged between 20.4-23.2\%, the clarified volume between $385-410 \mathrm{ml}$ and the $\%$ total solids between 0.39-0.69 g/g. The efficiency for controls ranged between $77-82 \%$ and concentration factor was between 2.3-3.8 (Table 4.2, Appendix B, Tables B.2 and B.3).

The addition of Calloway 4910 and Acco-Phos 1250 had little effect on \% total solids, clarified volume, percent settled sludge, efficiency and concentration factor at concentrations of $60 \mathrm{ppm}$ and lower (Table 4.2, Figures $4.13-4.17$ respectively). The results from the analysis of variance $(A N O V A)$ test conducted on the \% total solids, clarified volume, percent settled sludge for flocculant addition at $120 \mathrm{pm}$ are shown in Table 4.4. The addition of Calloway 4910 at $120 \mathrm{ppm}$ increased the $\%$ total solids to 2.02 $\pm 0.16 \mathrm{~g} / \mathrm{g}$ which was significantly greater than for any other concentration (ANOVA, $\mathrm{p}<0.001$ and Figure 4.13). Similarly, the addition of $120 \mathrm{ppm}$ Acco-Phos 1250 increased

$\%$ total solids $(2.48 \pm 0.23 \mathrm{~g} / \mathrm{g})$ significantly $(A N O V A, \mathrm{p}<0.001$ and Figure 4.13$)$. The addition of 120 ppm Calloway 4910 or Acco-Phos 1250 also increased clarified volume to $458 \pm 6 \mathrm{ml}$ and $461 \pm 5 \mathrm{ml}$, respectively (Table 4.2 and Figure 4.14). These increases were also statistically significant (ANOVA, Calloway $4910 \mathrm{p}<0.001$ and Kruskal-Wallis, 
Acco-Phos $1250 \mathrm{p}=0.008$ ). Unlike $\%$ total solids, there was a statistically significant increase in clarified volume from the control value with the addition of $60 \mathrm{ppm}$ Calloway 4910 (ANOVA, $\mathrm{p}=0.04)$. There was also a statistically significant increase in clarified volume between $40 \mathrm{ppm}$ and $120 \mathrm{ppm}$ Acco-Phos 1250 (Kruskal-Wallis, $\mathrm{p}=0.008$ ). The addition of Calloway 4910 or Acco-Phos 1250 at any concentration had no effect on \% settled sludge (ANOVA $\mathrm{p}=0.96$ and $\mathrm{p}=0.84$, Figure 4.15)). The efficiency increased to above $90 \%$ and concentration factor to 10.0 with the addition of Calloway 4910 and Acco-Phos 1250, at $120 \mathrm{ppm}$ (Figures 4.16 and 4.17).

Unlike the other two flocculants, the addition of Alco Clear ACP had deleterious effects on dewatering of sludge collected before primary settling. The addition of Alco Clear ACP did not cause a significant change in $\%$ total solids at any concentration (ANOVA, $\mathrm{p}=0.27$ and Figure 4.13). There was a statistically significant decrease in clarified volume with the addition of $120 \mathrm{ppm}$ Alco Clear ACP as compared with the control (ANOVA, $\mathrm{p}=0.041$ and Figure 4.14). It significantly increased $\%$ settled sludge above the control values (ANOVA, $\mathrm{p}<0.001$ and Figure 4.15). Efficiency and concentration factor decreased as the concentration of Alco Clear ACP increased (Figures 4.14 and 4.16). 
Table 4.5: Analysis of variance results for flocculants added to the sludge samples collected before primary settling.

\begin{tabular}{|c|c|c|c|c|}
\hline Flocculant & Parameter & $\begin{array}{c}\text { Variances } \\
\text { Homogeneous } \\
(\mathrm{Y} / \mathrm{N})\end{array}$ & $\begin{array}{c}P \\
\text { value }\end{array}$ & $\begin{array}{c}\text { Statistically } \\
\text { Significant } \\
\text { Difference* }^{*} \\
(\mathbf{Y} / \mathbf{N} ; \mathbf{P}<\mathbf{0 . 0 5})^{+}\end{array}$ \\
\hline Calloway 4910 & $\begin{array}{l}\% \text { Total Solids } \\
\% \text { Settled Sludge } \\
\text { Clarified Volume }\end{array}$ & $\begin{array}{l}\mathrm{Y} \\
\mathrm{Y} \\
\mathrm{Y}\end{array}$ & $\begin{array}{l}0.000 \\
0.957 \\
0.000\end{array}$ & $\begin{array}{l}\mathrm{Y} \\
\mathrm{N} \\
\mathrm{Y}\end{array}$ \\
\hline Alco Clear ACP & $\begin{array}{l}\% \text { Total Solids } \\
\% \text { Settled Sludge } \\
\text { Clarified Volume }\end{array}$ & $\begin{array}{c}\mathrm{Y} \\
\mathrm{Y}^{* *} \\
\mathrm{Y}\end{array}$ & $\begin{array}{l}0.270 \\
0.000 \\
0.032\end{array}$ & $\begin{array}{l}\mathrm{N} \\
\mathrm{Y} \\
\mathrm{Y}\end{array}$ \\
\hline Acco-Phos 1250 & $\begin{array}{l}\% \text { Total Solids } \\
\% \text { Settled Sludge } \\
\text { Clarified Volume }\end{array}$ & $\begin{array}{c}\mathrm{Y} \\
\mathrm{Y} \\
\mathrm{N}^{* * *}\end{array}$ & $\begin{array}{c}0.000 \\
0.838 \\
-\end{array}$ & $\begin{array}{l}\mathrm{Y} \\
\mathrm{N} \\
-\end{array}$ \\
\hline
\end{tabular}

* If significant differences were detected between flocculant concentrations, post-hoc multiple comparison tests were done to determine which concentrations were significantly different for that parameter.

** Variances homogeneous after log transformation of the data. *** Variances heterogeneous even after log transformation. + Zar 1999.

The percent settled sludge for Calloway 4910 and Acco-Phos 1250 at 120 ppm concentration may be inaccurate as lumps of sludge were formed and the final height of the sludge (needed to calculate percent settled sludge) was difficult to measure. The third sludge sample collected on June 8, 2004 behaved oddly. Rather than settling, the sludge was floating on water after $24 \mathrm{hrs}$ at a concentration of 40 and $120 \mathrm{ppm}$ for Alco Clear ACP; and 40, 60 and 120 ppm for Acco-Phos 1250. 


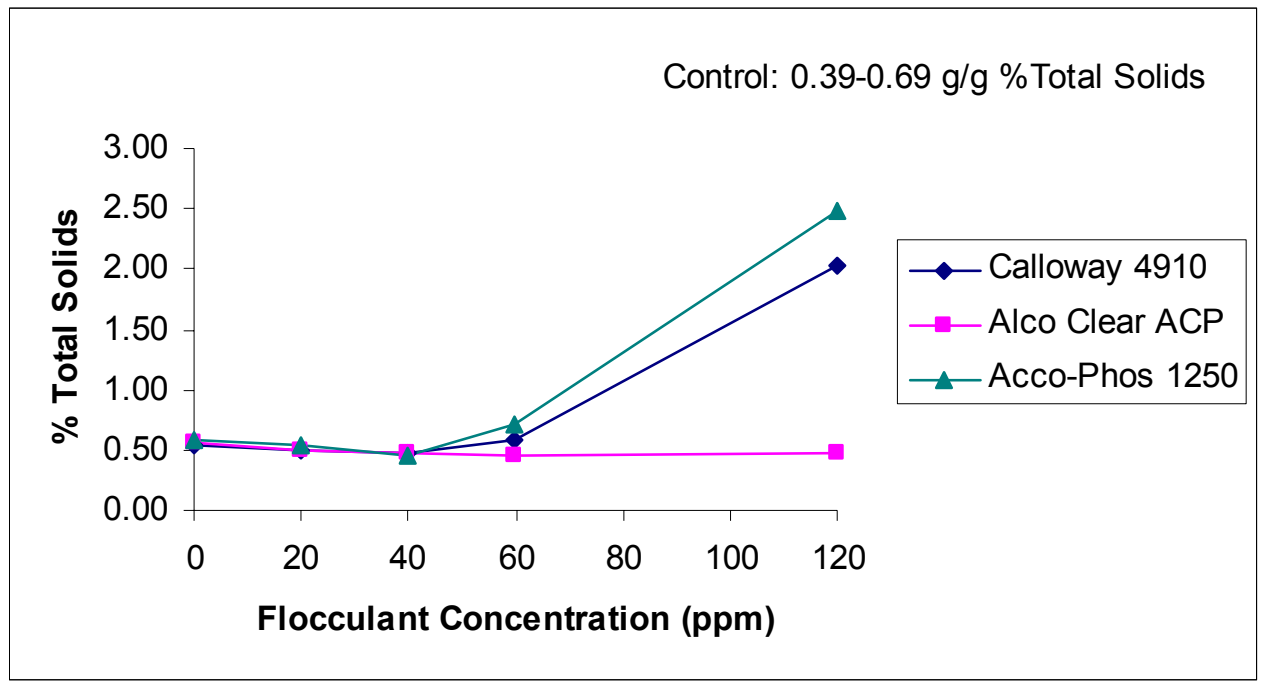

Figure 4.13: Effect of flocculant concentration on \% total solids for sludge collected before primary settling.

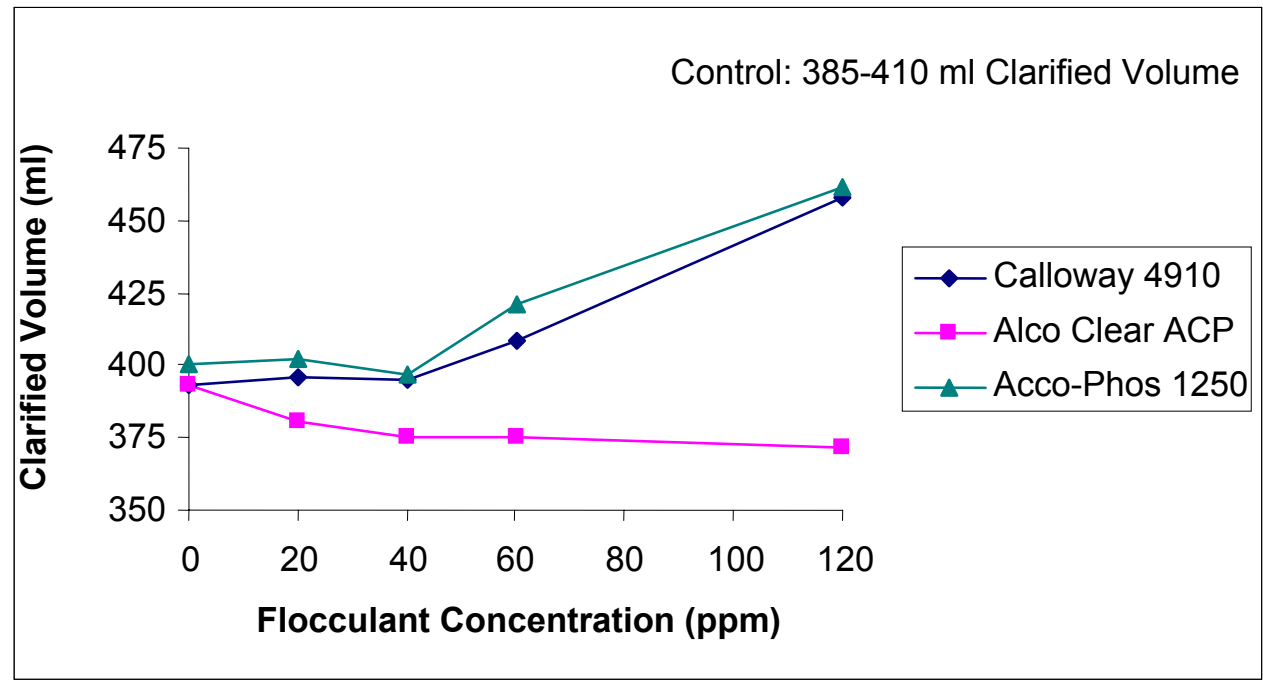

Figure 4.14: Effect of flocculant concentration on clarified volume for sludge collected before primary settling. 


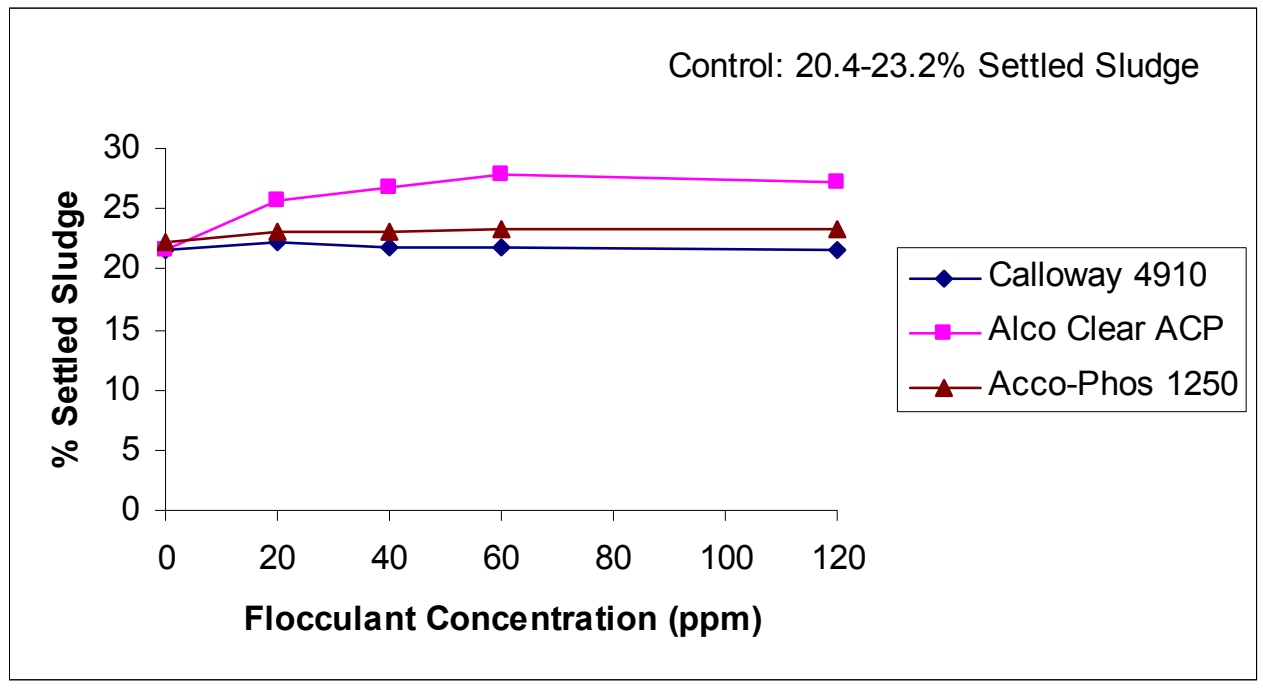

Figure 4.15: Effect of flocculant concentration on \% settled sludge for sludge collected before primary settling.

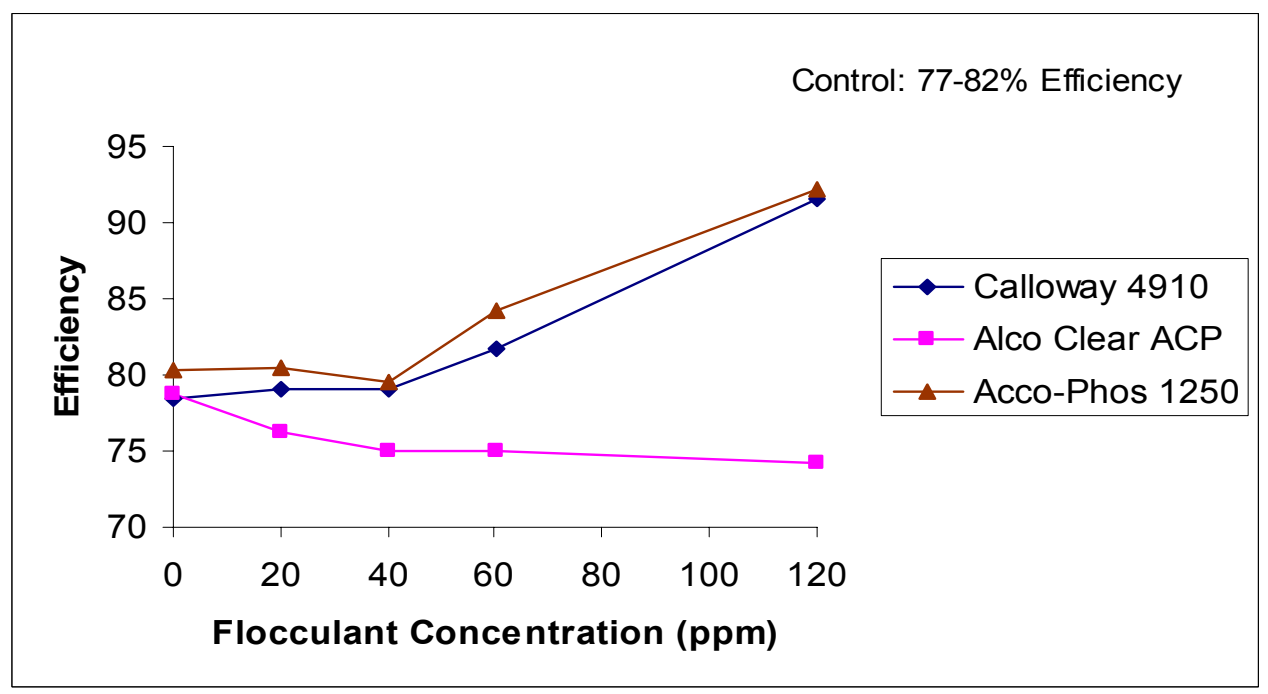

Figure 4.16: Effect of flocculant concentration on efficiency for sludge collected before primary settling. 


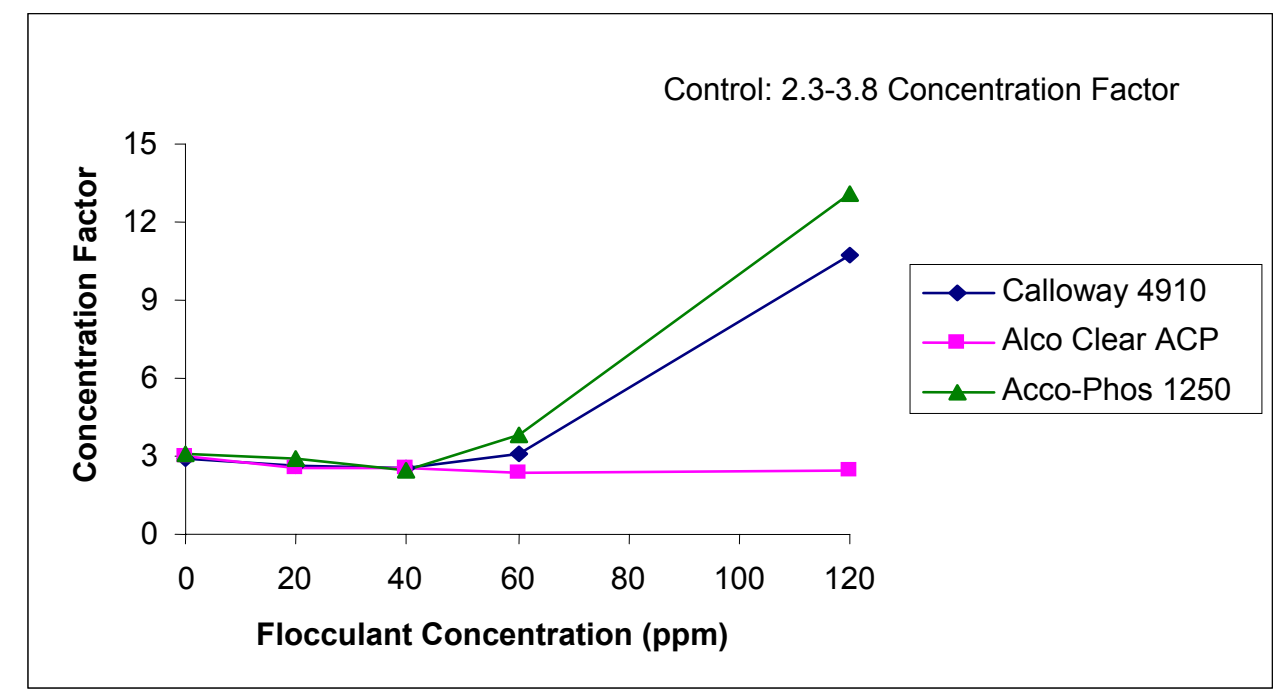

\section{Figure 4.17: Effect of flocculant concentration on concentration factor for sludge collected before primary settling.}

\subsubsection{Sludge Collected After Primary Settling}

The floc in the control ( 0 ppm flocculant concentration) took more than 5 hours to settle. The settling rate was not affected by the addition of flocculant. For controls, the $\%$ settled sludge ranged between $62.7-88.0 \%$, the clarified volume between $50-187 \mathrm{ml}$ and the $\%$ total solids between $0.82-1.55 \mathrm{~g} / \mathrm{g}$. The efficiency for controls ranged between 10 37\% and concentration factor was between 1.1-1.9 (Table 4.3, Appendix B, Tables B.5 and B.6).

The $\%$ settled sludge generally decreased as the concentration of flocculants increased (Figure 4.18). The clarified volume and the efficiency decreased slightly as the concentration of flocculants increased (Figures 4.19 and 4.20). The one exception was an increase in clarified volume for Calloway 4910 at $120 \mathrm{ppm}$. The $\%$ total solids and the concentration factor were not affected with the addition of flocculants at any of the concentrations studied and remained similar to that of controls (Figures 4.21 and 4.22). There was no statistically (ANOVA) significant difference between any of the parameters 
for any of the flocculant additions as shown in Table 4.5, which means flocculant addition is not a treatment option for sludge collected after primary settling.

Table 4.6: Results from the analysis of variance test for flocculants added to the sludge samples collected after primary settling.

\begin{tabular}{|c|c|c|c|c|}
\hline Flocculant & Parameter & $\begin{array}{c}\text { Variances } \\
\text { Homogeneous } \\
(\mathrm{Y} / \mathrm{N})\end{array}$ & $\begin{array}{c}P \\
\text { value }\end{array}$ & $\begin{array}{c}\text { Statistically } \\
\text { Significant } \\
\text { Difference } \\
(\mathbf{Y} / \mathbf{N} ; \mathbf{P}<\mathbf{0 . 0 5})\end{array}$ \\
\hline \multirow{3}{*}{ Calloway 4910} & \% Total Solids & $\mathrm{Y}$ & 0.990 & $\mathrm{~N}$ \\
\hline & $\%$ Settled Sludge & $\mathrm{Y}$ & 0.956 & $\mathrm{~N}$ \\
\hline & Clarified Volume & $\mathrm{Y}$ & 0.970 & $\mathrm{~N}$ \\
\hline \multirow{3}{*}{ Alco Clear ACP } & $\%$ Total Solids & $\mathrm{Y}$ & 0.990 & $\mathrm{~N}$ \\
\hline & $\%$ Settled Sludge & $\mathrm{Y}$ & 0.952 & $\mathrm{~N}$ \\
\hline & Clarified Volume & $\mathrm{Y}$ & 0.998 & $\mathrm{~N}$ \\
\hline \multirow{3}{*}{ Acco-Phos 1250} & \% Total Solids & Y & 1.000 & $\mathrm{~N}$ \\
\hline & $\%$ Settled Sludge & $\mathrm{Y}$ & 0.973 & $\mathrm{~N}$ \\
\hline & Clarified Volume & $\mathrm{Y}$ & 0.998 & $\mathrm{~N}$ \\
\hline
\end{tabular}

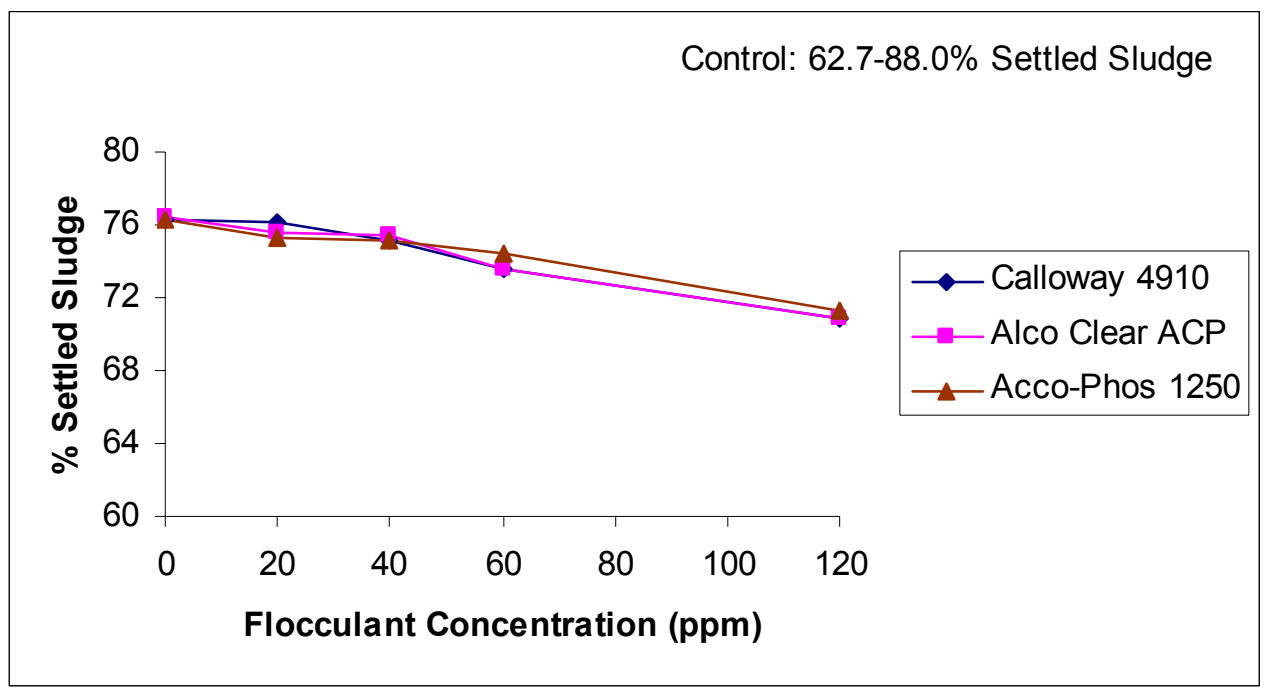

Figure 4.18: Effect of flocculant concentration on \% settled sludge for sludge collected after primary settling. 


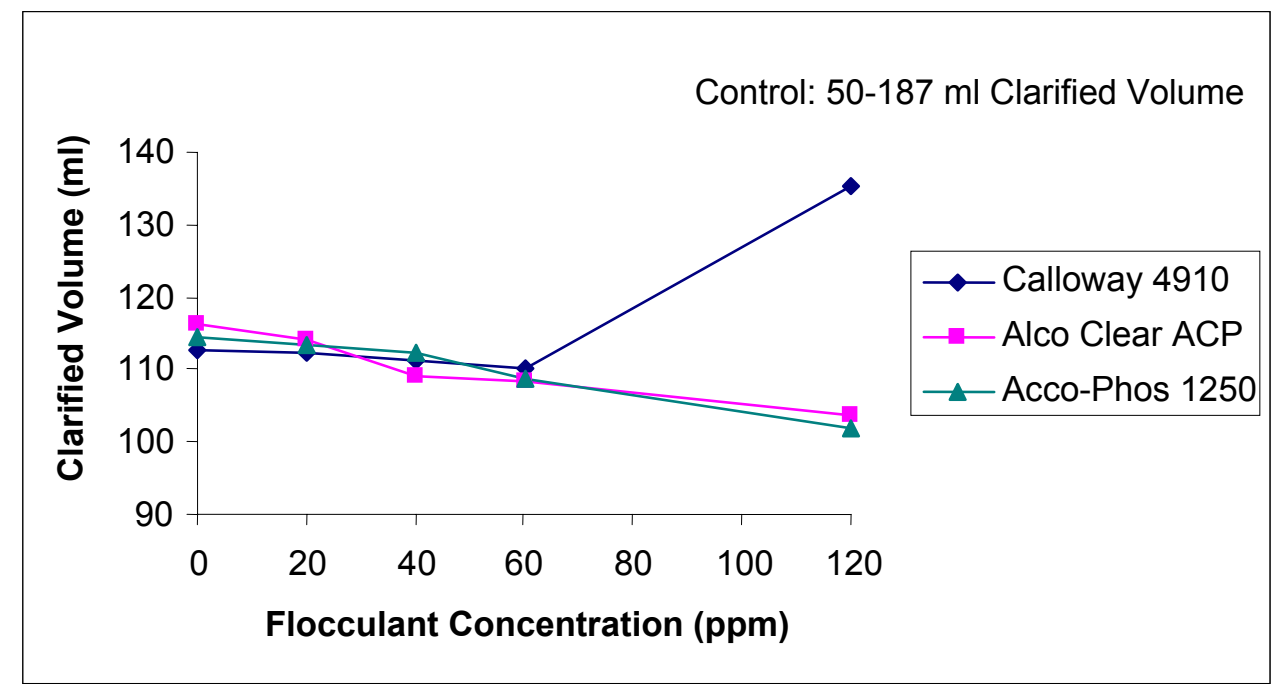

Figure 4.19: Effect of flocculant concentration on clarified volume for sludge collected after primary settling.

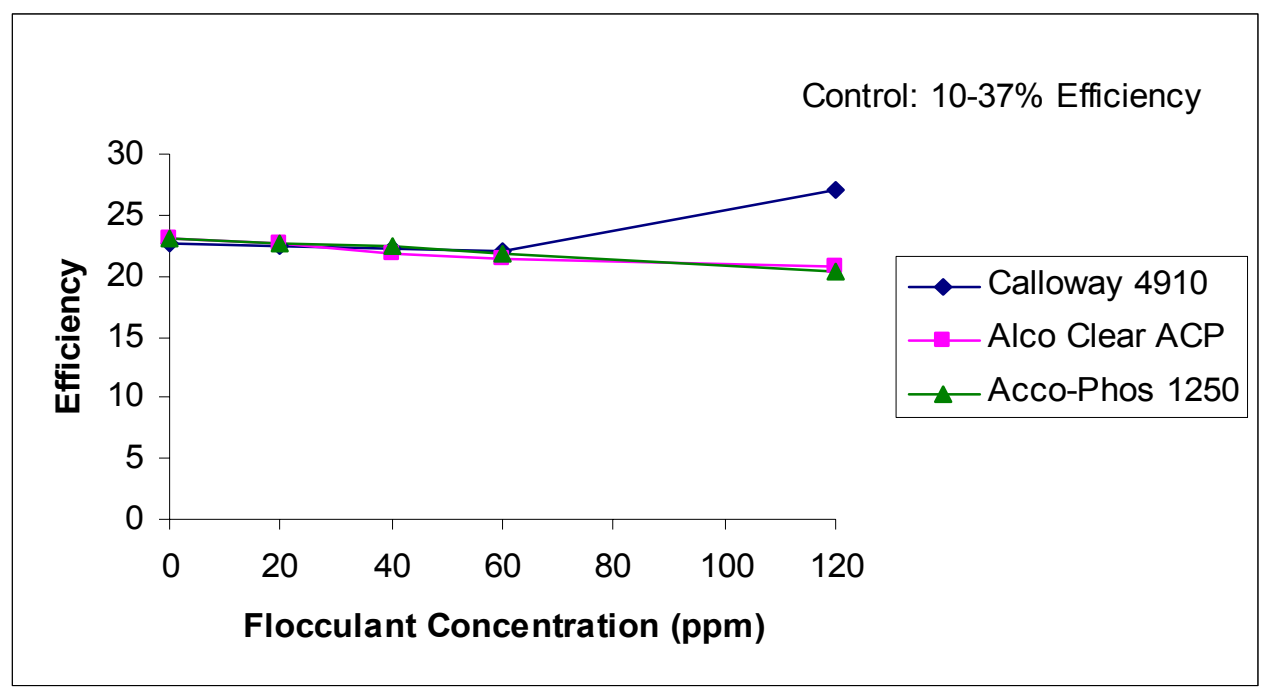

Figure 4.20: Effect of flocculant concentration on efficiency for sludge collected after primary settling. 


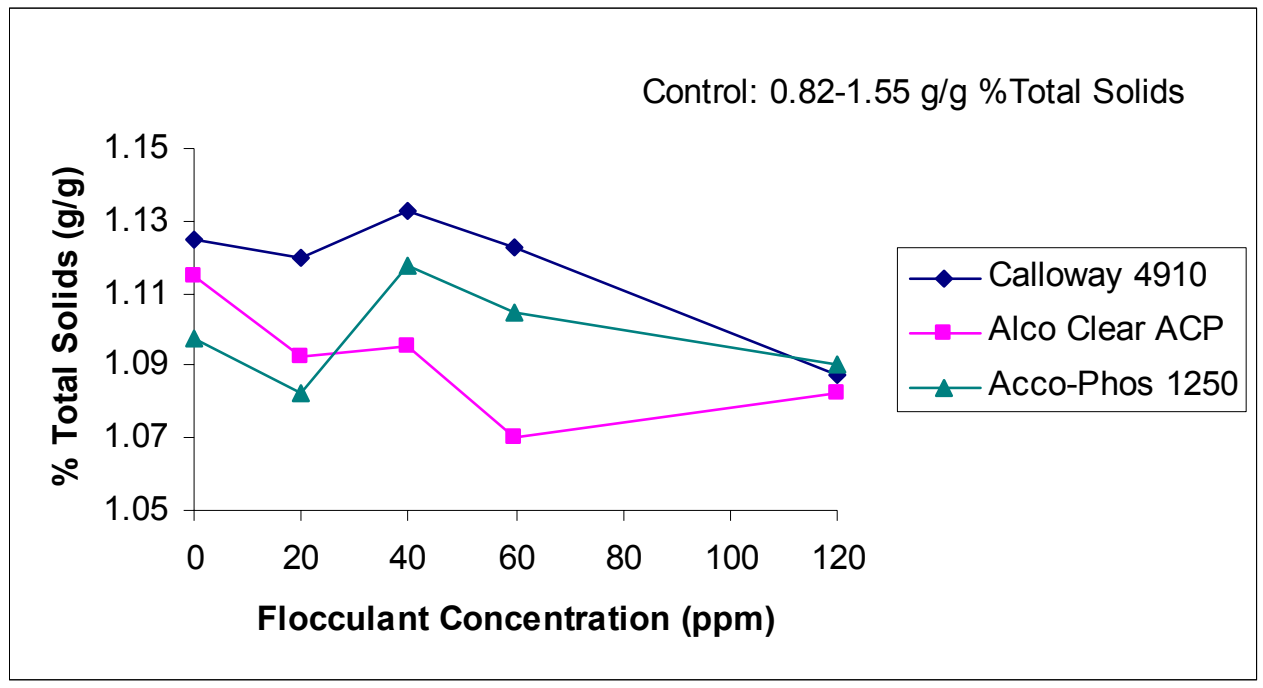

Figure 4.21: Effect of flocculant concentration on \% total solids for sludge collected after primary settling.

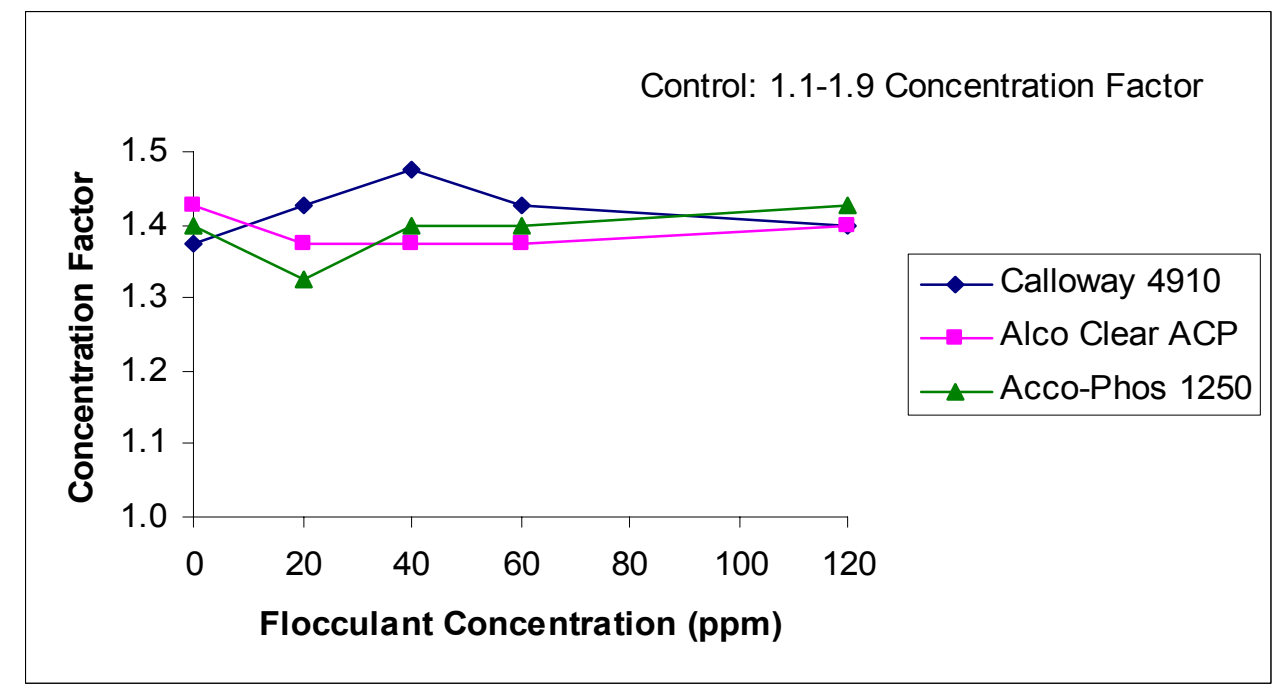

Figure 4.22: Effect of flocculant concentration on concentration factor for sludge collected after primary settling.

\subsubsection{Vacuum Filtration After Flocculant Addition}

The initial \% solids and the initial total volume were $0.18 \pm 0.02 \mathrm{~g} / \mathrm{g}$ and $202 \mathrm{ml}$ respectively, for the sludge collected before primary settling on which vacuum filtration was performed after the addition of flocculant, Acco-Phos 1250. The addition of Acco- 
Phos 1250 had a deleterious effect on the performance of vacuum filtration. The final \% total solids obtained from vacuum filtration after the addition of Acco-Phos 1250 was $2.24 \pm 0.31 \mathrm{~g} / \mathrm{g}$ with a concentration factor of $12.5 \pm 1.7$. The filtrate volume was $186 \pm 1$ $\mathrm{ml}$ with an efficiency of $91.9 \pm 0.6$. 


\section{CHAPTER 5: DISCUSSION}

\subsection{Aging Experiments}

\subsubsection{Effects of Storage Temperature}

$\mathrm{pH}$ was the only parameter affected by storage temperature. The $\mathrm{pH}$ of the sludge sample stored at $20^{\circ} \mathrm{C}$ decreased over time with a greater decrease in the sludge sampled weekly (from a value of 7.76 to 6.80 ). However, the time taken to observe the aging effects on metal hydroxide precipitates was not cited in the literature. The change in $\mathrm{pH}$ might be due to contact between and dissociation of mineral solids followed by hydration of aqueous phase metal hydroxides and subsequent behavior as acids. The samples mainly contain metals like $\mathrm{Fe}^{3+}$ and $\mathrm{Al}^{3+}$ (previously presented in Table 4.1). As AMD is formed by the contamination of natural waters, the aqueous phase hydroxide species of $\mathrm{Fe}^{3+}$ and $\mathrm{Al}^{3+}$ are as shown in Table 5.1. These aqueous phase metal hydroxides become hydrated in the presence of water and form complexes to release protons $\left(\mathrm{H}^{+} / \mathrm{H}_{3} \mathrm{O}^{+}\right)$into the solution and thereby decreasing the $\mathrm{pH}$ of the solution as shown in Equations 5.1-5.18 (Snoeyink and Jenkins 1980).

Table 5.1: Hydroxide species of $\mathrm{Fe}^{3+}$ and $\mathrm{Al}^{3+}$ (Source: Snoeyink and Jenkins 1980).

\begin{tabular}{|c|c|}
\hline Species of Fe(III) & Species of $\mathrm{Al}(\mathrm{III})^{*}$ \\
\hline $\mathrm{Fe}\left(\mathrm{H}_{2} \mathrm{O}\right)_{6}{ }^{3+}$ & $\mathrm{Al}\left(\mathrm{H}_{2} \mathrm{O}\right)_{6}{ }^{3+}$ \\
\hline $\mathrm{FeOH}^{2+}$ & $\mathrm{Al}(\mathrm{OH})^{2+}$ \\
\hline $\mathrm{Fe}(\mathrm{OH})_{2}^{+}$ & $\mathrm{Al}_{7}(\mathrm{OH})_{17}^{4+}$ \\
\hline $\mathrm{Fe}(\mathrm{OH})_{3}(\mathrm{~s})$ & $\mathrm{Al}_{13}(\mathrm{OH})_{34}{ }^{5+}$ \\
\hline $\mathrm{Fe}(\mathrm{OH})_{4}^{-}$ & $\mathrm{Al}(\mathrm{OH})_{3}(\mathrm{~s})$ \\
\hline \multirow[t]{2}{*}{$\mathrm{Fe}_{2}(\mathrm{OH})_{2}{ }^{4+}$} & $\mathrm{Al}(\mathrm{OH})_{4}{ }^{-}$ \\
\hline & $\mathrm{Al}_{2}(\mathrm{OH})_{2}{ }^{4+}$ \\
\hline
\end{tabular}

* Freshly precipitated Aluminum hydroxide 


$$
\begin{aligned}
& \mathrm{Fe}\left(\mathrm{H}_{2} \mathrm{O}\right)_{6}{ }^{3+}+\mathrm{H}_{2} \mathrm{O} \leftrightarrow \mathrm{Fe}\left(\mathrm{H}_{2} \mathrm{O}\right)_{5}(\mathrm{OH})^{2+}+\mathrm{H}_{3} \mathrm{O}^{+} \\
& \mathrm{Fe}\left(\mathrm{H}_{2} \mathrm{O}\right)_{5}(\mathrm{OH})^{2+}+\mathrm{H}_{2} \mathrm{O} \leftrightarrow \mathrm{Fe}\left(\mathrm{H}_{2} \mathrm{O}\right)_{4}(\mathrm{OH})_{2}{ }^{+}+\mathrm{H}_{3} \mathrm{O}^{+} \\
& \mathrm{Fe}\left(\mathrm{H}_{2} \mathrm{O}\right)_{4}(\mathrm{OH})_{2}^{+}+\mathrm{H}_{2} \mathrm{O} \leftrightarrow \mathrm{Fe}\left(\mathrm{H}_{2} \mathrm{O}\right)_{3}(\mathrm{OH})_{3}{ }^{o}(a q)+\mathrm{H}_{3} \mathrm{O}^{+} \\
& \mathrm{Fe}\left(\mathrm{H}_{2} \mathrm{O}\right)_{3}(\mathrm{OH})_{3}{ }^{o}(a q)+\mathrm{H}_{2} \mathrm{O} \leftrightarrow \mathrm{Fe}\left(\mathrm{H}_{2} \mathrm{O}\right)_{2}(\mathrm{OH})_{4}{ }^{-}+\mathrm{H}_{3} \mathrm{O}^{+} \\
& \mathrm{Fe}^{3+}+\mathrm{H}_{2} \mathrm{O} \leftrightarrow \mathrm{FeOH} \mathrm{H}^{2+}+\mathrm{H}^{+} \\
& \mathrm{FeOH}{ }^{2+}+\mathrm{H}_{2} \mathrm{O} \leftrightarrow \mathrm{Fe}(\mathrm{OH})_{2}^{+}+\mathrm{H}^{+} \\
& \mathrm{Fe}(\mathrm{OH})_{2}^{+}+\mathrm{H}_{2} \mathrm{O} \leftrightarrow \mathrm{Fe}(\mathrm{OH})_{3}+\mathrm{H}^{+} \\
& \mathrm{Fe}(\mathrm{OH})_{3}+\mathrm{H}_{2} \mathrm{O} \leftrightarrow \mathrm{Fe}(\mathrm{OH})_{4}^{-}+\mathrm{H}^{+} \\
& \mathrm{Fe}(\mathrm{OH})_{4}^{-}+\mathrm{H}_{2} \mathrm{O} \leftrightarrow \mathrm{Fe}(\mathrm{OH})_{5}^{2-}+\mathrm{H}^{+} \\
& \mathrm{Al}\left(\mathrm{H}_{2} \mathrm{O}\right)_{6}{ }^{3+}+\mathrm{H}_{2} \mathrm{O} \leftrightarrow \mathrm{Al}\left(\mathrm{H}_{2} \mathrm{O}\right)_{5}(\mathrm{OH})^{2+}+\mathrm{H}_{3} \mathrm{O}^{+} \\
& \mathrm{Al}\left(\mathrm{H}_{2} \mathrm{O}\right)_{5}(\mathrm{OH})^{2+}+\mathrm{H}_{2} \mathrm{O} \leftrightarrow \mathrm{Al}\left(\mathrm{H}_{2} \mathrm{O}\right)_{4}(\mathrm{OH})_{2}^{+}+\mathrm{H}_{3} \mathrm{O}^{+} \\
& \mathrm{Al}\left(\mathrm{H}_{2} \mathrm{O}\right)_{4}(\mathrm{OH})_{2}^{+}+\mathrm{H}_{2} \mathrm{O} \leftrightarrow \mathrm{Al}\left(\mathrm{H}_{2} \mathrm{O}\right)_{3}(\mathrm{OH})_{3}{ }^{o}(s)+\mathrm{H}_{3} \mathrm{O}^{+} \\
& \mathrm{Al}\left(\mathrm{H}_{2} \mathrm{O}\right)_{3}(\mathrm{OH})_{3}{ }^{o}(\mathrm{~s})+\mathrm{H}_{2} \mathrm{O} \leftrightarrow \mathrm{Al}\left(\mathrm{H}_{2} \mathrm{O}\right)_{2}(\mathrm{OH})_{4}{ }^{-}+\mathrm{H}_{3} \mathrm{O}^{+} \\
& \mathrm{Al}^{3+}+\mathrm{H}_{2} \mathrm{O} \leftrightarrow \mathrm{Al}(\mathrm{OH})^{2+}+\mathrm{H}^{+} \\
& \mathrm{Al}(\mathrm{OH})^{2+}+\mathrm{H}_{2} \mathrm{O} \leftrightarrow \mathrm{Al}(\mathrm{OH})_{3}+\mathrm{H}^{+} \\
& \mathrm{Al}(\mathrm{OH})_{3}+\mathrm{H}_{2} \mathrm{O} \leftrightarrow \mathrm{Al}(\mathrm{OH})_{4}^{-}+\mathrm{H}^{+} \\
& \mathrm{Al}_{7}(\mathrm{OH})_{17}{ }^{4+}+\mathrm{H}_{2} \mathrm{O} \leftrightarrow \mathrm{Al}_{7}(\mathrm{OH})_{18}{ }^{3+}+\mathrm{H}^{+} \\
& A l_{13}(\mathrm{OH})_{34}{ }^{5+}+\mathrm{H}_{2} \mathrm{O} \leftrightarrow \mathrm{Al}_{13}(\mathrm{OH})_{35}{ }^{4+}+H^{+}
\end{aligned}
$$

Equation 5.1

Equation 5.2

Equation 5.3

Equation 5.4

Equation 5.5

Equation 5.6

Equation 5.7

Equation 5.8

Equation 5.9

Equation 5.10

Equation 5.11

Equation 5.12

Equation 5.13

Equation 5.14

Equation 5.15

Equation 5.16

Equation 5.17

Equation 5.18 
From the $\mathrm{pC}-\mathrm{pH}$ diagrams for the hydroxo Fe(III) species shown in Figure 5.1, the most predominant aqueous species of $\mathrm{Fe}(\mathrm{III})$ at a $\mathrm{pH}$ of $\sim 4.5-8$ is $\mathrm{Fe}(\mathrm{OH})_{2}{ }^{+}($Snoeyink and Jenkins 1980). The decrease in $\mathrm{pH}$ can be accounted due to the hydration of $\mathrm{Fe}(\mathrm{OH})_{2}{ }^{+}$. The hydration of other aqueous species would also be possible. However, the influence of these species on the $\mathrm{pH}$ would be minor compared to the influence of $\mathrm{Fe}(\mathrm{OH})_{2}{ }^{+}$due to low concentrations of other species at $\mathrm{pH} \sim 4.5-8$.

Aluminum hydroxide precipitated freshly is more soluble than the aged and thermodynamically stable $\mathrm{Al}(\mathrm{OH})_{3}(\mathrm{~s})$ phase, Gibbsite (Snoeyink and Jenkins 1980). The pC-pH diagrams for the freshly precipitated and aged $\mathrm{Al}(\mathrm{OH})_{3}(\mathrm{~s})$ are shown in Figures 5.2 and 5.3. The $\mathrm{Al}(\mathrm{III})$ complexation in solution is greater for the freshly precipitated $\mathrm{Al}(\mathrm{OH})_{3}(\mathrm{~s})$ compared to the aged $\mathrm{Al}(\mathrm{OH})_{3}(\mathrm{~s})$, which predominates over a much larger region (Figure 5.3). Consequently, the decrease in the $\mathrm{pH}$ would be greater in the freshly precipitated $\mathrm{Al}(\mathrm{OH})_{3}(\mathrm{~s})$ than the aged $\mathrm{Al}(\mathrm{OH})_{3}(\mathrm{~s})$.

The effects of temperature on these chemical reactions and their respective reaction rates can be explained using the Van't Hoff-Arrhenius Relationship between temperature and equilibrium constants, as shown in Equation 5.11 (Metcalf and Eddy 2000). For the temperatures $20^{\circ} \mathrm{C}$ and $4^{\circ} \mathrm{C}$ under consideration, the reaction rates are related by the Van't Hoff-Arrhenius Equation as shown in Equation 5.12 and the reaction rate at $20^{\circ} \mathrm{C}$ is greater than the reaction rate at $4^{\circ} \mathrm{C}$ by a factor of 1.462 . Consequently, the hydration of aqueous phase hydroxide species will be greater at $20^{\circ} \mathrm{C}$ than at $4^{\circ} \mathrm{C}$.

$$
\frac{K_{2}}{K_{1}}=e^{\frac{E\left(T_{2}-T_{1}\right)}{R T_{1} T_{2}}}
$$

\section{Equation 5.11}

where, $\quad \mathrm{K}_{1}$ and $\mathrm{K}_{2}$ are the reaction rate constants at temperatures $\mathrm{T}_{1}$ and $\mathrm{T}_{2}, \mathrm{~K}$ $\mathrm{E}=$ activation energy, $\mathrm{J} /$ mole 


$$
\begin{aligned}
& \mathrm{R} \text { = ideal gas constant, } 8.314 \mathrm{~J} / \mathrm{mol} . \mathrm{K} \\
& \begin{array}{ll}
K_{20^{\circ}}=K_{4^{\circ}} \theta^{\left(20^{\circ}-4^{\circ}\right)}=1.462 K_{4^{\circ}} & \text { Equation } 5.12
\end{array}
\end{aligned}
$$

where, $\quad \theta \equiv e^{\frac{E}{R T_{1} T_{2}}} \equiv 1.024$ is a constant (Chapra 1997).

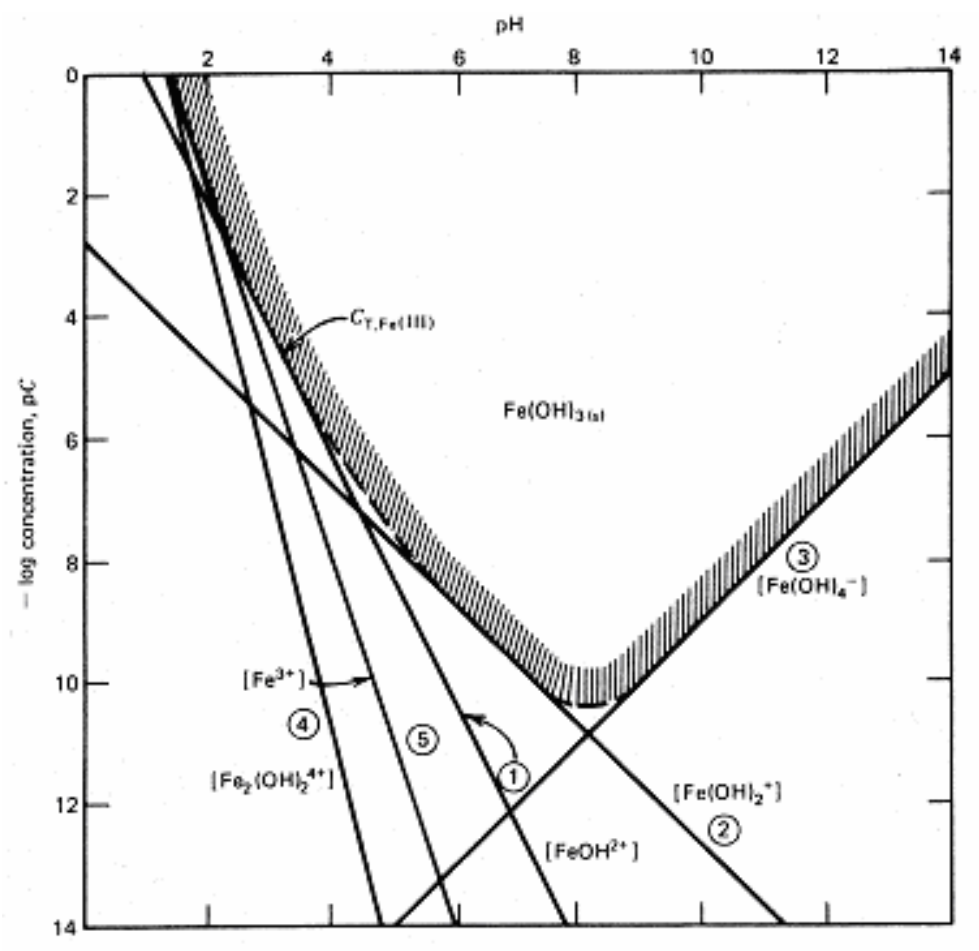

Figure 5.1: Hydroxo $\mathrm{Fe}(\mathrm{III})$ species for $\mathrm{Fe}(\mathrm{OH})_{3}(\mathrm{~s})$ (Source: Snoeyink and Jenkins 1980). 


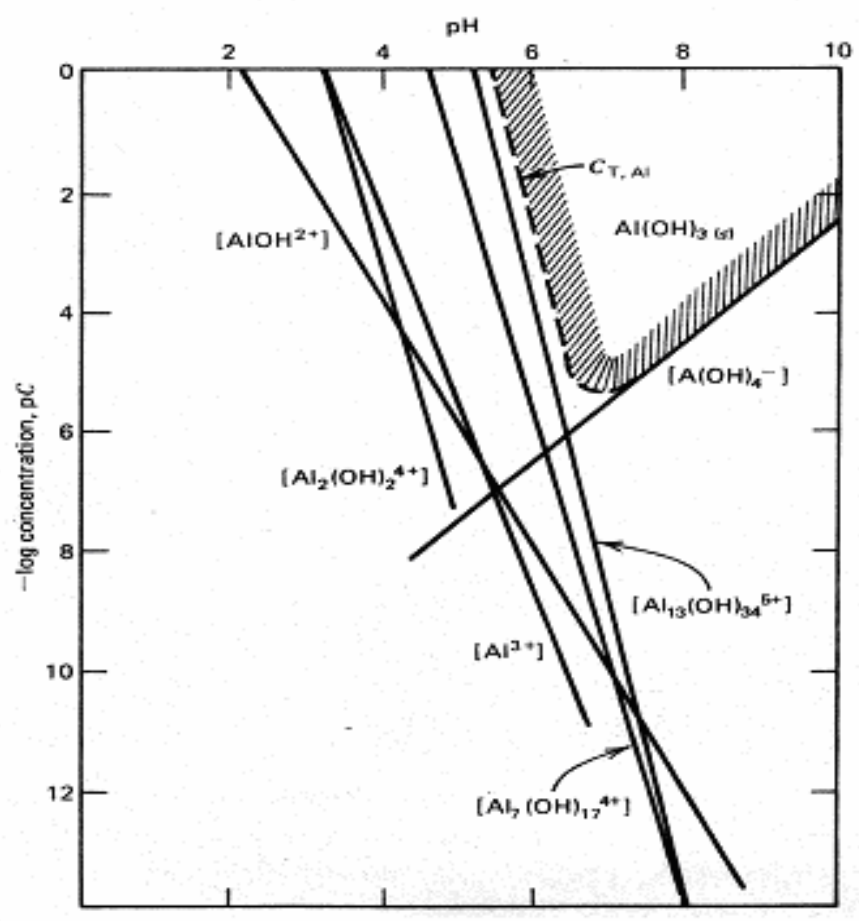

Figure 5.2: Hydroxo Al(III) species for freshly precipitated $\mathrm{Al}(\mathrm{OH})_{3}(\mathrm{~s})$ (Source: Snoeyink and Jenkins 1980).

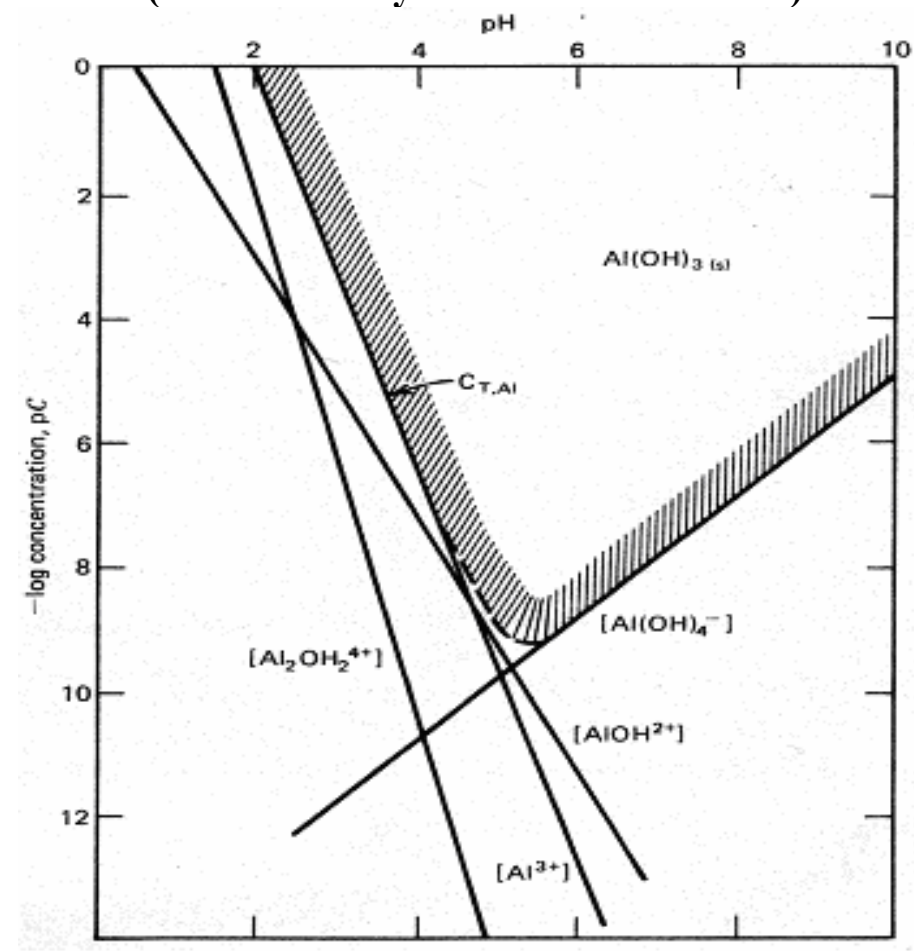

Figure 5.3: Hydroxo $\mathrm{Al}(\mathrm{III})$ species for the aged $\mathrm{Al}(\mathrm{OH})_{3}(\mathrm{~s})$ (Source: Snoeyink and Jenkins 1980). 


\subsubsection{Effects of Aging and Mixing}

$\mathrm{pH}$ decreased over time for samples stored at $20^{\circ} \mathrm{C}$. $\mathrm{pH}$ would have been affected due to the processes described earlier. Specific conductance increased over time at all storage conditions. However, when compared with the order of magnitude of measurements, the increase was minor. $\mathrm{pH}$ and specific conductance were not affected by mixing. The changes in percent settled sludge, SRF, viscosity and particle size with time and mixing were so small that they will not affect any practical application.

No previous experiments on the effects of aging, temperature and mixing were conducted to compare the results from this study. However, the effects of aging on sludge decomposition rates (Brawn and Beckett 2003), effects of time and temperature on dissolved organic carbon (DOC) and elemental release from a metal contaminated site (Martinez et al. 2003), and the effects of temperature and microbial activity on the leaching of trace elements from peat soils (Qureshi et al. 2003) were discussed. The effects of temperature on the metabolic activities of microbial populations in an anaerobic digestion process were also discussed (Metcalf and Eddy 2000). However, this lacks direct application to the site.

Although the sludge properties were affected by storage temperature, time and mixing; the change of each was so minor that it will not effect any practical application, except the change in $\mathrm{pH}$ of sludge stored at $20^{\circ} \mathrm{C}$ and sampled weekly. However, the change in one property cannot be considered a major effect compared to all the properties under consideration. It was concluded that the sludge properties were not affected with temperature $\left(4^{\circ} \mathrm{C}\right.$ or $\left.20^{\circ} \mathrm{C}\right)$. However, temperature may become important during summer 
if the temperature is $>20^{\circ} \mathrm{C}$ for a sustained period of time and a future study may be needed.

\subsection{Effect of Dewatering Treatment Methods}

\subsubsection{Recommended Dewatering Method for Sludge Collected Before Primary Settling}

Vacuum filtration and addition of Calloway 4910 and Acco-Phos 1250 at 120 ppm concentration were effective in dewatering the sludge collected before primary settling based on volume of water removed, \% total solids, efficiency and concentration factor (Table 5.1). Although the clarified volume and the efficiency of Calloway 4910 and Acco-Phos 1250 were the same, the $\%$ total solids and the concentration factor were higher for Acco-Phos 1250. Consecutively, Acco-Phos 1250 at a concentration of 120 ppm was the most effective flocculant in dewatering the sludge samples collected before primary settling. The $\%$ total solids, volume of water removed, efficiency and the concentration factor were higher for vacuum filtration compared to flocculant addition (Acco-Phos 1250 at $120 \mathrm{ppm}$ ) and was the most effective dewatering method for sludge samples collected before primary settling.

No previous experiments were reported for the application of vacuum filtration to dewater the ammonia-neutralized AMD sludge to compare the results from this study. The $\%$ total solids obtained using vacuum filtration for various types of municipal sludges were higher compared to the $\%$ total solids obtained from the sludge samples collected before primary settling and are shown in Table 5.2. However, municipal sludges contain organic constituents and the initial total solids in the municipal sludges are greater than the initial total solids in the ammonia-neutralized AMD sludge which may have affected the results. The $\%$ total solids obtained using vacuum filtration for 
sludges of nickel hydroxide, cupric hydroxide and electroplating waste were in the range of $9-15 \%, 11-20 \%$, and $13-17 \%$ respectively.

Table 5.1: Parameters for the effective dewatering methods applied on sludge samples collected before and after primary settling.

\begin{tabular}{|c|c|c|c|c|c|}
\hline Method & $\begin{array}{c}\% \text { Initial } \\
\text { Total } \\
\text { Solids (g/g) }\end{array}$ & $\begin{array}{c}\text { \% Final } \\
\text { Total } \\
\text { Solids } \\
\text { (g/g) }\end{array}$ & $\begin{array}{l}\text { Volume of } \\
\text { Water } \\
\text { Removed } \\
(\mathrm{ml})\end{array}$ & Efficiency & $\begin{array}{l}\text { Conc. } \\
\text { Factor }\end{array}$ \\
\hline $\begin{array}{l}\text { Vacuum } \\
\text { Filtration* }\end{array}$ & $0.19 \pm 0.03$ & $9.12 \pm 0.6$ & $174 \pm 1$ & $96.75 \pm 0.5$ & $48.29 \pm 8.2$ \\
\hline $\begin{array}{l}\text { Calloway 4910* } \\
(120 \mathrm{ppm})\end{array}$ & $0.19 \pm 0.03$ & $2.02 \pm 0.2$ & $458 \pm 6$ & $91.50 \pm 1.3$ & $10.70 \pm 1.9$ \\
\hline $\begin{array}{l}\text { Acco-Phos 1250* } \\
(120 \mathrm{ppm})\end{array}$ & $0.19 \pm 0.03$ & $2.48 \pm 0.2$ & $461 \pm 5$ & $92.25 \pm 1.0$ & $13.13 \pm 2.7$ \\
\hline $\begin{array}{c}\text { Vacuum } \\
\text { Filtration** }\end{array}$ & $0.84 \pm 0.3$ & $6.72 \pm 0.7$ & $164 \pm 7$ & $91.00 \pm 3.5$ & $8.85 \pm 3.0$ \\
\hline $\begin{array}{c}\text { Pressure } \\
\text { Filtration** }\end{array}$ & $0.84 \pm 0.3$ & $9.88 \pm 0.3$ & $166 \pm 5$ & $92.00 \pm 2.6$ & $13.37 \pm 5.9$ \\
\hline
\end{tabular}

* Sludge collected before primary settling

** Sludge collected after primary settling

Table 5.2: Typical solids in cake obtained by using vacuum filtration.

\begin{tabular}{|c|c|}
\hline Sludge Type & Cake Solids (\%) \\
\hline Raw Primary ${ }^{1}$ & $27-35$ \\
\hline $\begin{array}{c}\text { Primary \& Air Activated } \\
\text { Sludge }^{1}\end{array}$ & $18-25$ \\
\hline Air Activated Sludge ${ }^{1}$ & $13-20$ \\
\hline $\begin{array}{c}\text { Anaerobically Digested } \\
\text { Primary }^{1}\end{array}$ & $25-35$ \\
\hline $\begin{array}{c}\text { Anaerobically Digested } \\
\text { Primary \& Activated Sludge }{ }^{1}\end{array}$ & $18-25$ \\
\hline Nickel Hydroxide ${ }^{2 *}$ & $9-15$ \\
\hline Cupric Hydroxide ${ }^{2 *}$ & $11-20$ \\
\hline Electroplating Waste $^{2 *}$ & $13-17$ \\
\hline
\end{tabular}




\subsubsection{Recommended Dewatering Method for Sludge Collected After Primary Settling}

Vacuum filtration and pressure filtration were effective in dewatering the sludge collected after primary settling based on filtrate volume, \% total solids, efficiency and concentration factor (Table 5.1). Although the filtrate volume and the efficiency for vacuum filtration and pressure filtration were almost the same, the \% total solids and the concentration factor were higher for pressure filtration. Consequently, pressure filtration was judged to be the more effective dewatering method for sludge collected after primary settling.

No previous experiments were conducted using pressure filtration to dewater the AMD sludge to compare the results from this study. The $\%$ total solids obtained using pressure filtration for various types of municipal sludges were higher compared to the $\%$ total solids obtained from the sludge samples collected after primary settling and are shown in Table 5.3. However, the initial total solids in the municipal sludges are greater than the initial total solids in the AMD sludge which may have affected the results.

Table 5.3: Typical solids in the cake obtained by using pressure filtration (Source: Metcalf and Eddy 2000).

\begin{tabular}{ccc}
\hline Sludge Type & Dry Feed Solids (\%) & Cake Solids (\%) \\
\hline Raw Primary & $3-7$ & $26-32$ \\
Waste-activated (WAS) & $1-4$ & $12-20$ \\
Primary + WAS (50:50)* & $3-6$ & $20-28$ \\
Anaerobically Digested & (Primary) & $24-30$ \\
$\begin{array}{c}\text { Aerobically Digested } \\
\text { (Primary + Activated Sludge) } \\
\text { Oxygen-activated WAS }\end{array}$ & $1-3$ & $12-20$ \\
\hline
\end{tabular}

* Ratio based on dry solids or the primary and WAS 


\subsubsection{Recommended Dewatering Method at the Treatment Site}

The most effective dewatering method for sludge collected before primary settling was vacuum filtration while the most effective dewatering method for sludge collected after primary settling was pressure filtration. The filtrate volume and the final total solids obtained from both methods were almost the same. Although the efficiency for vacuum filtration and pressure filtration were almost the same, the concentration factor for vacuum filtration was greater than the concentration factor for pressure filtration. However, the difference in concentration factors was due to the difference in the initial total solids for the sludge collected before and after primary settling.

Pressure filtration failed to dewater sludge collected before primary settling although it was effective on sludge collected after primary settling. This could be explained based on the $\mathrm{pC}-\mathrm{pH}$ diagrams of Hydroxo $\mathrm{Al}(\mathrm{III})$ species presented previously in Figures 5.2 and 5.3. It can be clearly seen from these figures that the solubility of the aged aluminum hydroxide species is less than that of freshly precipitated species. The hydroxide species would tend to be more in the solid phase in the aged sludge. Due to increased contact, the mineral solids tend to accumulate on the surface of one another, thereby, increasing the particle size. Consequently, pressure filtration worked on the sludge collected after primary settling.

The ultimate goal of a dewatering method is to increase the filtrate volume (reduce the moisture content of the sludge) and the final total solids. This in turn improves the efficiency and concentration factor of a dewatering method. The sludge samples collected after primary settling have already been partially dewatered by settling at the site. However, the amount of water removed by settling could not be accounted for 
in this study. As dewatering at either point in the process produced similar results, the process economics would determine which is the best dewatering method for the site.

\subsubsection{Pros and Cons of Using Vacuum Filtration at the Treatment Site}

Using vacuum filtration on a full-scale generally involves the addition of polymers (coagulants and flocculants) for sludge conditioning. Addition of flocculants without the application of either vacuum or pressure filtration was effective on the sludge samples collected before primary settling. However, the addition of Acco-Phos 1250 had a deleterious effect on the performance of vacuum filtration.

Complete removal of solids (insoluble metal hydroxides) would be a problem if the sludge is dewatered immediately after chemical addition as observed in the experiments. Skilled personnel are not required to continuously operate vacuum filtration equipment. However, vacuum filters require continuous operator attention and consume more energy per unit sludge dewatered (Metcalf and Eddy 1991).

\subsubsection{Pros and Cons of Using Pressure Filtration at the Treatment Site}

Using pressure filtration on a full-scale generally involves the addition of polymers (coagulants and flocculants) for sludge conditioning. Addition of flocculants was not effective on the sludge samples collected after primary settling. From an engineering and economic point of view, dewatering the sludge entering the drying pond is more energy intensive compared to dewatering the sludge entering the primary settling pond as the sludge needs to be pumped to the drying ponds. 
Pumping the sludge to the drying ponds would be a problem in winter as the temperatures may freeze the pipes. The time required to dewater the sludge collected after primary settling increased as the $\%$ initial total solids increased and was far greater than the time required to dewater the sludge collected before primary settling. This might be due to the clogging of the filter paper pores by the suspended solids whose particle size increases as a result of agglomeration on long standing. The amount of cake formed by sludge collected after primary settling was greater than with sludge collected before primary settling, which can be overcome by using a scraper to remove the solids formed on a continuous basis.

Pressure filtration (belt presses) consume low energy, require low capital and operating costs, and can be easily maintained (USEPA 2000, Metcalf and Eddy 1991). However, automatic operation of the equipment is not advisable and washing the belt at the end of each shift can be time consuming (USEPA 2000, Metcalf and Eddy 1991).

\subsubsection{Economics of Vacuum and Pressure Filtration at the Treatment Site}

The full-scale vacuum filtration equipment that can be used is a precoat discharge rotary drum vacuum filter with a 100 sq. ft filter supplied by Komline-Sanderson Engineering Corporation, NJ. The full-scale pressure filtration equipment that can be used at the treatment site is the Phoenix model LC-800L skid-mounted belt filter press supplied by the Phoenix Process Equipment Company, KY. Typical costs associated with these two equipments are shown in Table 5.4.

The following assumptions were made in the economic analysis of using vacuum filtration and pressure filtration at the treatment site. The engineering costs and the 
maintenance costs were assumed to be $\sim 10 \%$ each of the capital costs respectively based on the AMDTreat program supplied by Office of Surface Mining (OSM 2004). The precoat discharge rotary drum vacuum filter can be used for dilute sludges and even at higher pumping rates (Tom O'Leary, Personal Communication). The vacuum filter needs a precoat (diatomaceous earth) on the filter media to protect it from blinding effects and easy removal of the cake. The belt filter press can be used to dewater the sludge collected after primary settling with pumping rates of $25-35 \mathrm{gpm}$ and minimum feed solids of $0.4 \%$ $\mathrm{g} / \mathrm{g}$. The primary settling tank at the treatment site (refer Figures 3.1 and 3.3) can be used as a tank to mix the flocculant. The total head to pump the sludge from primary settling pond to the drying ponds was $\sim 240 \mathrm{ft}$ and the pumping costs were obtained using the AMDTreat program supplied by the Office of Surface Mining (OSM 2004). The sludge was assumed to be pumped once every 3 days at $8 \mathrm{hr} /$ day.

The total annual costs were almost the same for vacuum filtration and pressure filtration. However, vacuum filtration was found to have greater capital costs than pressure filtration. Further, the filter media for vacuum filtration needs to be coated with the precoat twice a day.

From an economic point of view, using pressure filtration to dewater the sludge collected after primary settling is recommended. However, to avoid the problems associated with pumping the sludge to the drying pond (freezing of pipes in winter), using vacuum filtration to dewater the sludge collected before primary settling is recommended. Another recommendation would be using pressure filtration to dewater sludge collected after primary settling near the primary settling pond rather than pumping the sludge to the drying pond. 
Table 5.4: Typical costs associated with vacuum and pressure filtration at the treatment site.

\begin{tabular}{ccc}
\hline Costs & $\begin{array}{c}\text { Pressure } \\
\text { Filtration }\end{array}$ & $\begin{array}{c}\text { Vacuum } \\
\text { Filtration }^{2}\end{array}$ \\
\hline Capital Costs $(\$)$ & $107,500.00$ & $125,000.00$ \\
Engineering $\operatorname{Costs}^{3}(\$)$ & $10,750.00$ & $12,500.00$ \\
Maintenance Costs ${ }^{4}(\$ / \mathrm{yr})$ & $10,750.00$ & $12,500.00$ \\
Pumping Costs $(\$ / \mathrm{yr})$ & $3,524.00$ & - \\
Precoat Costs ${ }^{5}(\$ / 25 \mathrm{lbs})$ & - & 20.00 \\
Total Annual Costs $(\$ / \mathrm{yr})$ & $25,024.00$ & $25,000.00$ \\
\hline${ }^{1}$ Phoenix model LC-800L skid-mounted belt filter press \\
${ }^{2}$ Precoat discharge rotary drum vacuum filter with a 100 sq. $\mathrm{ft}$ filter \\
${ }^{3}$ Engineering costs were assumed to be 10\% of the capital costs \\
${ }^{4}$ Maintenance costs were assumed to be 10\% of the capital costs \\
${ }^{5}$ Diatomaceous earth is generally used as a precoat
\end{tabular}

\subsubsection{Beneficial Uses of the Concentrated Sludge from the Treatment Site}

The beneficial uses of the concentrated sludge from the treatment site can be summarized as follows:

1. The concentrated AMD sludge can be used as a raw material in pigment production. The iron oxide sludge from an abandoned coal mine in southwestern Pennsylvania, USA was used as a raw material in pigment production and the finished product was superior in several pigmentary characteristics compared to the finished products from natural goethite ores (Hedin 2002). However, the finished material was difficult to handle and difficult to dry due to a moisture content of $50 \%$ compared to the finished product from mined iron oxide products (moisture content $<10 \%$ ). The presence of aluminum in the sludge limits the usage of the AMD sludge (Robert Hedin, personal communication). 
2. The AMD sludge can be used as a raw material in the preparation of controlled low strength materials (CLSM) which can be used to fill trenches and as structural fills. A CLSM has properties similar to a stabilized soil and needs to have a compressive strength between $65 \mathrm{psi}$ and 1,200 psi to be classified as a CLSM (Gabr and Bowders 2000). It was proposed that CLSM's developed using > 90\% of Class F fly ash and AMD sludge from calcium hydroxide treatment plant can successfully emulate natural soils (Monson 1997). AMD sludge was used in the CLSM mixes up to $10 \%$ by weight. The CLSM's met the ACI Committee 22928 day unconfined compressive strength of $>50$ psi. In another study conducted using 10\% AMD sludge from lime treatment, 2.5\% Portland cement, and 87.5\% class F fly ash with water had a compressive strength within the range of CLSM classification, satisfied the excavatability, walkability, hardening time and stability criteria requirements (Gabr and Bowders 2000). However, lab and pilot scale tests need to be performed to test the feasibility of AMD sludge obtained by ammonia treatment.

3. AMD sludge can be used to prevent soluble phosphorus losses from soil and manure to the water environment which may lead to eutrophication (Adler and Sibrell 2003). AMD flocs obtained by using limestone, lime, ammonium hydroxide, and sodium hydroxide as neutralizing agents were used in phosphorus sequestration from water, soil, and manure storage bins (Adler and Sibrell 2003). The flocs adsorbed 10-20 g P/kg dry floc in water and about $70 \%$ of water extractable P was adsorbed by the flocs when applied at $20 \mathrm{~g}$ floc/kg soil. 
4. The AMD sludge can be land applied to soils where bio-mass accumulation is needed as the sludge has nitrogen present in the form of $\mathrm{NH}_{3}$ and $\mathrm{NO}_{3}$. Moreover, the AMD sludge does not have toxic heavy metals like $\mathrm{As}, \mathrm{Cd}, \mathrm{Cu}, \mathrm{Hg}, \mathrm{Pb}, \mathrm{Mo}$, $\mathrm{Ni}, \mathrm{Zn}$ and Se which are regulated by EPA for land filling applications. However, greenhouse experiments and pilot scale tests need to be performed to determine the feasibility of land application of AMD sludge.

5. The AMD sludge, which is alkaline in nature, can be used as a neutralizing agent for strip mine soils and aid in revegetation of mined areas (Simonyi and Grady 1977).

6. The metal hydroxides in AMD can be separated from each other by selective precipitation. This research is being currently conducted by WVU-CEE researchers. Once separated, the metal hydroxides can be used for various purposes.

7. The AMD sludge can be used in the preparation of particulate permeation grouts which are used to fill interstitial voids and fissures in rock or soil, in highway applications to control seepage in granular soils and fractured rock. A study was conducted by using fly ash and AMD sludge in the preparation of particulate permeation grout (Gabr et al. 1995). A mix consisting 50\% AMD sludge and 50\% fly ash had the best characteristics with respect to pozzolan content and flow reduction. Bench scale studies showed that grouting reduced the hydraulic conductivity by one to two orders of magnitude and $59-64 \%$ of the voids were grouted. 
8. The AMD sludge can be used in the preparation of concrete as a replacement to sand and silt fine aggregates. In a study conducted by Khanbilvardi and Afshari (1995), concrete mixes were prepared for a 28-day compressive strength of 3,000 psi based on American Concrete Institute (ACI) standards, by replacing sand and silt fine aggregates with ash. It was concluded that the fine aggregates can be replaced up to $30 \%$ by weight of ash, which had a 28 -day compressive strength of 3,299 psi. However, the composition of ash used in the study was different from the AMD sludge and contained the metals silver, arsenic, barium, cadmium, and chromium. Lab and pilot scale studies need to be performed for the replacement of fine aggregates with AMD sludge.

9. The AMD sludge can be used to prepare cementitious binders. Singh and Garg (1999) concluded that fly ash can be used in the range of $45-70 \%$ in the preparation of cementitious binders. In addition, they concluded that the binders can replace the cement in concrete by up to $25 \%$ by mass. Lab and pilot scale studies need to be performed in using AMD sludge to prepare cementitious binders. 


\section{CHAPTER 6: SUMMARY AND CONCLUSIONS}

\subsection{Novelty of the Work}

No other anhydrous ammonia treated AMD sludge removal was cited in the literature.

\subsection{Purpose of the Study}

The aging experiment was conducted to determine the effects of aging, storage temperature $\left(20^{\circ} \mathrm{C}\right.$ and $\left.4^{\circ} \mathrm{C}\right)$ and time on the AMD sludge and establish the optimum storage conditions. This experiment was conducted to determine if aging, storage temperature and mixing affect the dewatering of AMD sludge which would further affect our approach to dewatering treatment. The dewatering experiment was conducted to determine and compare the effectiveness of three dewatering treatment methods on the sludge collected before and after primary settling collected at the treatment site.

\subsection{Effect of Aging, Temperature and Mixing on Sludge Properties}

The sludge properties considered for the aging experiment were $\mathrm{pH}$, specific conductance, percent settled sludge, viscosity, specific resistance to filtration (SRF) and particle size distribution. All the properties were measured in triplicate except $\mathrm{pH}$ and specific conductance, for which single readings were taken. $\mathrm{pH}$ and specific conductance were measured using YSI model 63 meter. Percent settled sludge was measured using the 24 hour jar settling test, viscosity using Brookfield DV-III programmable rheometer, SRF using Buchner funnel test and particle size using Beckmann Coulter LS230 analyzer.

$\mathrm{pH}$ was the only parameter affected by storage temperature $\left(20^{\circ} \mathrm{C}\right)$, decreasing over time with a greater decrease in the sludge sampled weekly (from a value of 7.76 to 6.80). However, the time taken to observe the aging effects on metal hydroxide 
precipitates was not cited in the literature. Specific conductance increased over time at all storage conditions. However, when compared with the order of magnitude of measurements, the increase was minor. $\mathrm{pH}$ and specific conductance were not affected by mixing. The changes in percent settled sludge, SRF, viscosity and particle size with time and mixing were so small that they will not affect any practical application.

Although the sludge properties were affected by storage temperature, time and mixing; the effect of each was minor except the change in $\mathrm{pH}$ of sludge stored at $20^{\circ} \mathrm{C}$ and sampled weekly. The decrease in the $\mathrm{pH}$ might be due to hydration of aqueous metal hydroxide species in the solution and subsequently behaving as acids. However, the change in one property cannot be considered a major effect compared to all the properties under consideration. It was concluded that the sludge can be stored at any temperature $\left(4^{\circ} \mathrm{C}\right.$ or $\left.20^{\circ} \mathrm{C}\right)$. However, temperature may become important during summer if the temperature is $>20^{\circ} \mathrm{C}$ for a sustained period of time and a future study may be needed.

\subsection{Effect of Dewatering Treatment Methods}

Three dewatering methods were considered: vacuum filtration, pressure filtration and flocculant addition. Vacuum filtration was assessed using the Buchner Funnel apparatus at a vacuum of $50,796 \mathrm{~Pa}(15 \mathrm{in} \mathrm{Hg})$ on $180 \mathrm{ml}$ of the sample. Pressure filtration was assessed using Amicon cells model 8200 apparatus at a pressure of 137,895 Pa (20 psi) on $180 \mathrm{ml}$ of the sample. Whatman filter paper No.2, with a medium fine porosity and a particle retention $>8 \mu \mathrm{m}$, was used for vacuum filtration and pressure filtration. The flocculants applied on $500 \mathrm{ml}$ of the sludge were Calloway 4910, Alco Clear ACP and Acco-phos 1250 at a concentration of 0, 20, 40, 60 and $120 \mathrm{ppm}$. The dewatering methods were evaluated based on volume of water removed, \% total solids, 
efficiency and concentration factor. Efficiency was measured as the ratio of volume of water removed to the initial sludge volume. Concentration factor was the ratio of final total solids to the initial total solids.

Vacuum filtration was the most effective dewatering method for sludge collected before primary settling, increasing the $\%$ total solids from $0.19 \pm 0.03 \mathrm{~g} / \mathrm{g}$ to $9.1 \pm 0.6$ $\mathrm{g} / \mathrm{g}$. It removed $174 \pm 1 \mathrm{ml}$ of filtrate, concentrating the sludge by a factor of $48.3 \pm 8.2$. The efficiency of vacuum filtration was $96.8 \pm 0.5 \%$.

Pressure filtration was the most effective dewatering method for the sludge collected after primary settling increasing the $\%$ total solids from $0.84 \pm 0.3 \mathrm{~g} / \mathrm{g}$ to $9.9 \pm$ $0.3 \mathrm{~g} / \mathrm{g}$ and removed $166 \pm 5 \mathrm{ml}$ of filtrate, concentrating the sludge by a factor of $13.4 \pm$ 5.9. The efficiency of pressure filtration was $92.0 \pm 2.6 \%$.

The ultimate goal of a dewatering method is to increase the filtrate volume and the final total solids. This in turn improves the efficiency and concentration factor of a dewatering method. The sludge samples collected after primary settling have already been partially dewatered by settling at the site. However, the amount of water removed by settling could not be accounted in this study. As dewatering at either point in the process produces similar results, the process economics were evaluated to determine the best dewatering method that can be applied at this treatment site. Vacuum filtration was found to have greater total annual costs than pressure filtration. From an economic point of view, using pressure filtration to dewater the sludge collected after primary settling is recommended. However, to avoid the problems associated with pumping the sludge to the drying pond (freezing of pipes in winter), using vacuum filtration to dewater the sludge collected before primary settling is recommended. Another recommendation 
would be using pressure filtration to dewater sludge collected after primary settling near the primary settling pond rather than pumping the sludge to the drying pond. 


\section{CHAPTER 7: REFERENCES}

Ackman, T.E. 1982. "Sludge disposal from acid mine drainage treatment." Bureau of Mines, United States Department of Interior, Report of Investigations 8672.

Adler, P.R. and Sibrell, P.L. 2003. "Sequestration of Phosphorus by Acid Mine Drainage Floc." Journal of Environmental Quality 32 (3): 1122-1129.

APHA (American Public Health Association). 1997. Standard Methods for the Examination of Water and Wastewater. $20^{\text {th }}$ Edition. American Water Works Association, Water Environment Federation. Washington, D.C.

Aubertin, M. and Bussiere, B. 2001. "Meeting environmental challenges for mine waste management." Geotechnical News 19 (3): 21-26.

Barton, C.D. and Karathanasis, A.D. 1999. "Renovation of a failed constructed wetland treating acid mine drainage.” Environmental Geology 39 (1): 39-50.

Benner, S.G., Blowes, D.W. and Ptacek, C.J. 1997. "A full-scale porous reactive wall for prevention of acid mine drainage." Ground Water Monitoring \& Remediation 17 (4): 99107.

Blowes, D.W., Ptacek, C.J., Benner, S.G. and McRae, C.W.T. 1998. "Treatment of dissolved metals using permeable reactive barriers." Pp. 483-490. Groundwater Quality: Remediation and Protection, Proceedings of the GQ'98 Conference, Tubingen, Germany. IAHS Publication Number 250.

Brady, K., Smith, M.W., Beam, R.L. and Cravotta, C.A. 1990. "Effectiveness of the use of alkaline materials at surface coal mines in preventing or abating acid mine drainage: Part 2. Mine site case studies." pp. 227-241. Proceedings of the 1990 Mining and Reclamation Conference, West Virginia University, Morgantown, WV.

Braun, J. and Beckett, P. 2003. "Factors affecting decomposition properties of paper mill sludge spread on mine tailings." SUDBURY 2003-Mining and the Environment, Proceedings of the $28^{\text {th }}$ annual meeting on Mining and the Environment, Sudbury, Ontario, Canada.

Brenner, F.J. and Busler, S. 2003. "Efficiency of passive treatment systems for treating acid mine drainage and their impact on receiving streams." pp. 2347-2354. World Water \& Environmental Resources Congress, Philadelphia, PA.

Brookfield Engineering. 1999. "More solutions to sticky problems." Middleboro, MA. http://www.brookfieldengineering.com/support/documentation/index.cfm. (Assessed: September 10 ${ }^{\text {th }}, 2003$ ) 
Brown, H., Skousen, J. and Renton, J. 1994. "Floc generation by chemical neutralization of acid mine drainage." Green Lands 24 (1): 44-51.

Eckenfelder, Jr, W.W. 2000. Industrial Water Pollution Control. $3^{\text {rd }}$ Edition. The McGraw-Hill Companies, New York.

Faulkner, B., Skousen, J. and Sterner, P. 1995. "Passive treatment systems and improvement of water quality." Green Lands 25 (4): 31-38.

Faulkner, B.B. 1990. Handbook for use of Ammonia in treating mine waters. West Virginia Mining and Reclamation Association. Charleston, WV.

Fowler, T.A., Holmes, P.R. and Crundwell, F.K. 1999. "Mechanism of Pyrite Dissolution in the Presence of Thiobacillus ferrooxidans." Applied and Environmental Microbiology 65 (7): 2987-2993.

Fytas, K. and Evangelou, B. 1998. "Phosphate coating on pyrite to prevent acid mine drainage." International Journal of Surface Mining, Reclamation and Environment 12 (3): 101-104.

Gabr, M.A., Boury, E.M. and Bowders, J. J. 1995. "Leachate Characteristics of Fly Ash Stabilized with Lime Sludge.” Transportation Research Record, No. 1486: 13-20.

Gabr, M.A. and Bowders, J. J. 2000. "Controlled low-strength material using fly ash and AMD sludge.” Journal of Hazardous Materials 76 (2): 251-263.

Gazea, B., Adam, K. and Kontopoulos, A. 1996. "A review of passive treatment systems for the treatment of acid mine drainage." Minerals Engineering 9 (1): 23-42.

Georgopoulou, Z.J., Fytas, K. Soto, H. and Evangelou, B. 1996. "Feasibility and cost of creating an iron-phosphate coating on pyrrhotite to prevent oxidation." Environmental Geology 28 (2): 61-69.

Gibert, O., de Pablo, J., Cortina, J.L. and Ayora, C. 2003. "Evaluation of municipal compost/limestone/iron mixtures as filling material for permeable reactive barriers for insitu acid mine drainage treatment." Journal of Chemical Technology and Biotechnology 78: 489-496.

Girts, M.A. and Kleinmann, R.L.P. 1986. "Constructed wetlands for treatment of acid mine drainage: A preliminary review." pp. 165-171. Proceedings of the 1986 National Symposium on Mining, Hydrology, Sedimentology and Reclamation, University of Kentucky, Lexington, Kentucky.

Gray, N.F. 1997. "Environmental impact and remediation of acid mine drainage: A management problem.” Environmental Geology 30 (1/2): 62-71. 
Hedin, R.S. 2002. "Recovery of Marketable Iron Oxide from Mine Drainage." 2002 West Virginia Surface Mine Drainage Task Force Symposium, Morgantown, WV.

Hedin, R.S., Watzlaf, G.R. and Nairn, R.W. 1994. "Passive treatment of acid mine drainage with limestone.” Journal of Environmental Quality 23 (6): 1338-1345.

Hedin, R.S. 2004. Personal Communication.

Khanbilvardi, R. and Afshari, S. 1995. "Sludge Ash as Fine Aggregate for Concrete Mix.” Journal of Environmental Engineering 121 (9): 633-638.

Knocke, W.R., Ghosh, M.M. and Novak, J.T. 1980. "Vacuum Filtration of Metal Hydroxide Sludges." Proceedings of the American Society of Civil Engineers, Journal of the Environmental Engineering Division, 106 (EE2): 363-376.

Lilly, R. and Ziemkiewicz, P. 1992. "Manganese removal at a lower pH with Trapzene: Results of field trials." Thirteenth Annual West Virginia Surface Mine Drainage Task Force Symposium, Ramada Inn, Morgantown, West Virginia.

Martinez, C.E., Jacobson, A.R. and McBride, M.B. 2003. "Aging and temperature effects on DOC and elemental release from a metal contaminated soil." Environmental Pollution, 122:135-143.

McCabe, W.L., Smith, J.C. and Harriott, P. 1993. Unit Operations of Chemical Engineering. $5^{\text {th }}$ Edition. McGraw-Hill, Inc. New York.

Menendez, R., Clayton, J.L., Zurbuch, P.E., Sherlock, S.M., Rauch, H.W. and Renton, J.J. 2000. "Sand-sized limestone treatment of streams impacted by acid mine drainage." Water, Air and Soil Pollution 124 (3-4): 411-428.

MERG (Mining Environment Research Group). 2004. "Heavy Metals and Acid Rock Drainage: A Select Literature Review of Remediation and Recommendations for Applied Research." Department of Energy, Mines \& Resources, Government of Yukon, EBA File: 5100667, MERG Report 2004-2.

Metcalf \& Eddy, Inc. 1991. Wastewater Engineering: Treatment, Disposal, and Reuse. $3^{\text {rd }}$ Edition. McGraw-Hill, Inc. New York.

Metcalf \& Eddy, Inc. 2000. Wastewater Engineering: Treatment and Reuse. $4^{\text {th }}$ Edition. McGraw-Hill, Inc. New York.

Monson, T. 1997. "Engineering Properties of Controlled Low-Strength Material using Fly Ash / AMD Sludge.” Master's Thesis, West Virginia University, Morgantown, WV. 
Nyavor, K. and Egeibor, N.O. 1997. "Stability of phosphate coated pyrite in the presence of Thiobacillus ferrooxidans." Proceedings of the Thirteenth International Conference on Solid Waste Technology and Management, Philadelphia, PA.

Nyavor, K., Egiebor, N.O. and Fedorak, P.M. 1996. "Bacteria Oxidation of Sulfides During Acid Mine Drainage Formation: A Mechanistic Study.” pp. 269-287. EPD Congress 1996: Proceedings of Sessions \& Symposia sponsored by Extraction \& Processing Division, TMS Annual Meeting, Anaheim, CA.

O’Leary, T. 2004. Personal Communication.

OSM. 2004. "Acid mine drainage: Index." Office of Surface Mining, United States Department of Interior. http://www.osmre.gov/amdint.htm. (Assessed: July $3^{\text {rd }}, 2004$ ).

Peppas, A., Komnitsas, K. and Halikia, I. 2000. "Use of organic covers for acid mine drainage control.” Minerals Engineering 13 (5): 563-574.

Polat, M., Guler, E., Akar, G., Mordogan, H., Ipekoglu, U. and Cohen, H. 2002. "Neutralization of acid mine drainage by Turkish lignitic fly ashes; role of organic additives in the fixation of toxic elements." Journal of Chemical Technology and Biotechnology 77: 372-376.

Qureshi, S., Richards, B.K., McBride, M.B., Baveye, P. and Steenhuis, T.S. 2003. "Temperature and microbial activity effects on trace element leaching from metalliferous peats.” Journal of Environmental Quality, 32: 2067-2075.

Rastogi, V. 1994. "Control of mine water quality in coal rejects areas and coal stockpiles with bactericides." Proceedings of the $5^{\text {th }}$ International Mine Water Congress, Nottingham, U.K.

Robinson, J.D.F. and Robb, G.A. 1995. "Methods for the control and treatment of acid mine drainage." Coal International 243 (4): 151-156.

Sasaki, K., Ogina, T., Endo, Y. and Kurosawa, K. 2003. "Field study on heavy metal accumulation in a natural wetland receiving acid mine drainage." Materials Transactions 44 (9): 1877-1884.

Sencindiver, J.C. and Bhumla, D.K. 1988. "Effects of cattails (Typha) on metal removal from mine drainage." pp. 359-366. Mine Drainage and Surface Mine Reclamation, Vol. 1, Information Circular No. 9183, United States Bureau of Mines, Pittsburgh, PA.

Sencindiver, J.C. and Skousen, J.G. 1991. "Wetlands for acid mine drainage treatment." Energy in the 90's: 294-299. 
Simonyi, T. and Grady, W.C. 1977. "The Character and Utilization of the Sludge from Acid Mine Drainage Treatment Facilities.” Technical Report - West Virginia University, Coal Research Bureau, No. 165.

Singh, M. and Garg, M. 1999. "Cementitious Binder from Fly Ash and other Industrial Wastes." Cement and Concrete Research 29 (3): 309-314.

Skousen, J. 1988. "Chemicals for treating acid mine drainage." Green Lands 18 (2): 3640.

Skousen, J. 1991. "Anoxic limestone channels for acid mine drainage treatment." Green Lands 21 (4): 30-35.

Skousen, J. 1995. “Acid mine drainage.” Green Lands 25 (2): 52-55.

Skousen, J. 2004. Personal Communication.

Skousen, J., and Politan, K. 1993. "Remining in West Virginia." Green Lands 23 (2): 4246.

Skousen, J., Hilton, T. and Faulkner, B. 1996. "Overview of acid mine drainage treatment with chemicals." Green Lands 26 (3): 40-49.

Skousen, J., Lilly, R. and Hilton, T. 1993. "Special chemicals for treating acid mine drainage." Green Lands 23 (3): 34-41.

Skousen, J., Politan, K., Hilton, T. and Meek, A. 1990. "Acid mine drainage treatment systems: Chemicals and costs." Green Lands 20 (4): 31-37.

Skousen, J., Sencindiver, J. and Smith, R. 1987. "A review of procedures for surface mining and reclamation in areas with acid-producing materials." West Virginia University Energy Research Center, Morgantown, WV. Publication No. 871.

Skousen, J., Sexstone, A., Garbutt, K. and Sencindiver, J. 1992. "Wetlands for treating acid mine drainage." Green Lands 22 (4): 31-39.

Skousen, J.G., and Ziemkiewicz, P.F. 1996. Acid mine drainage control and treatment. $2^{\text {nd }}$ Edition. West Virginia University and the National Mine Land Reclamation Center. Morgantown, WV.

Snoeyink, S.L. and Jenkins, D. 1980. Water Chemistry. John Wiley \& Sons, Inc. New York.

Spratt, A.K. and Weider, R.K. 1988. "Growth responses and iron uptake in Sphagnum plants and their relation to acid mine drainage treatment" pp. 279-285. Mine Drainage and Surface Mine Reclamation, Vol. 1, Information Circular No. 9183, United States Bureau of Mines, Pittsburgh, PA. 
USEPA (United States Environmental Protection Agency). 1993. Nitrogen Control. Office of Research and Development, Office of Water, Washington, D.C., EPA/625/R93/010.

USEPA (United States Environmental Protection Agency). 2000. "Biosolids Technology Fact Sheet: Belt Filter Press.” Office of Water, Washington, D.C., EPA 832-F-00-057.

West Virginia University Extension Service. 2004. "Acid Mine Drainage Inventory in West Virginia." West Virginia University. http://www.wvu.edu/ agexten/landrec/acidmine.htm. (Assessed: May 20 ${ }^{\text {th }}, 2004$ ).

Wieder, R.K. and Lang, G.E. 1982. "Modification of acid mine drainage in a freshwater wetland." pp. 43-53. Proceedings of the Symposium on Wetlands of the Unglaciated Appalachian Region, West Virginia University, Morgantown, WV.

Yanful, E. K., Orlandea, M. P. and Eliasziw, M. 2000. "Controlling acid drainage in a pyritic mine waste rock. Part I: statistical analysis of drainage data." Water, Air and Soil Pollution 122 (3): 369-388.

Yanful, E.G., Abbe, B.A., Woyshner, M. and St-Arnaud, L.C. 1994. "Field and laboratory performance of engineered covers on the Waite Amulet tailings." pp. 138-147. Proceedings of the International Land Reclamation and Mine Drainage Conference. Bureau of Mines SP 06B-94, United States Department of Interior, Pittsburgh, PA.

Zar, J.H. 1999. Biostatistical Analysis. $4^{\text {th }}$ Edition, Prentice Hall, Inc. New Jersey.

Ziemkiewicz, P. and Skousen, J. 1996. "Overview of acid mine drainage at-source control strategies." Green Lands 26 (1): 45-52.

Ziemkiewicz, P., Skousen, J. and Lovett, R. 1994. "Open limestone channels for treating AMD: A new look at an old idea." Green Lands 24 (4): 31-38.

Ziemkiewicz, P.F., Skousen, J.G. and Simmons, J. 2003. "Long-term performance of passive acid mine drainage treatment systems." Mine Water and Envir., 22: 118-129.

Ziemkiewicz, P.F., Skousen, J.G., Brant, D.L., Sterner, P.L. and Lovett, R.J. 1997. “Acid mine drainage treatment with armored limestone in open limestone channels." Journal of Environmental Quality 26 (4): 1017-1024. 


\section{APPENDIX A: DATA FROM THE AGING EXPERIMENT}

Table A.1: Properties of sludge stored at $20^{\circ} \mathrm{C}$ and sampled weekly.

\begin{tabular}{|c|c|c|c|c|c|c|c|}
\hline $\begin{array}{c}\text { Property of the } \\
\text { sample }\end{array}$ & Initial & Week 1 & Week 2 & Week 3 & Week 4 & Week 6 & Week 7 \\
\hline pH & 7.76 & 7.82 & 7.79 & 7.64 & 7.36 & 7.20 & 6.80 \\
\hline $\begin{array}{c}\text { Specific } \\
\text { Conductance } \\
(\mu \mathrm{S} / \mathbf{c m})\end{array}$ & 4009 & 3975 & 4014 & 4047 & 4010 & 4031 & 4013 \\
\hline$\%$ Settled Sludge & N.D. & $55.0 \pm 0.0$ & $52.6 \pm 0.3$ & $54.0 \pm 0.3$ & $52.2 \pm 0.3$ & $52.6 \pm 0.7$ & $52.8 \pm 0.3$ \\
\hline $\begin{array}{c}\mathrm{SRF} \times\left(10^{7}\right) \\
\left(\sec ^{2} / \mathrm{gm}\right)\end{array}$ & N.D. & $\begin{array}{c}0.99 \pm \\
0.01\end{array}$ & $\begin{array}{c}0.93 \pm \\
0.04\end{array}$ & $\begin{array}{c}0.92 \pm \\
0.01\end{array}$ & $\begin{array}{c}0.83 \pm \\
0.03\end{array}$ & $\begin{array}{c}0.83 \pm \\
0.04\end{array}$ & $\begin{array}{c}0.80 \pm \\
0.01\end{array}$ \\
\hline $\begin{array}{l}\text { Viscosity } \\
\text { (cP) }\end{array}$ & 9.8 & $9.7 \pm 0.1$ & $9.7 \pm 0.1$ & $9.6 \pm 0.1$ & $9.4 \pm 0.1$ & $9.4 \pm 0.1$ & $9.3 \pm 0.1$ \\
\hline $\begin{array}{l}\text { Mean Particle } \\
\text { Size }(\mu \mathrm{m})\end{array}$ & 11.790 & $\begin{array}{c}9.893 \pm \\
0.020\end{array}$ & $\begin{array}{l}9.627 \pm \\
0.008\end{array}$ & $\begin{array}{l}9.582 \pm \\
0.063\end{array}$ & $\begin{array}{c}9.468 \pm \\
0.088\end{array}$ & $\begin{array}{c}9.538 \pm \\
0.046\end{array}$ & $\begin{array}{l}9.575 \pm \\
0.005\end{array}$ \\
\hline $\begin{array}{l}\text { Mode of Particle } \\
\text { Size }(\mu \mathrm{m})\end{array}$ & 11.290 & $\begin{array}{c}8.536 \pm \\
0.000\end{array}$ & $\begin{array}{c}7.775 \pm \\
0.000\end{array}$ & $\begin{array}{c}7.775 \pm \\
0.000\end{array}$ & $\begin{array}{c}7.775 \pm \\
0.000\end{array}$ & $\begin{array}{c}7.775 \pm \\
0.000\end{array}$ & $\begin{array}{c}7.775 \pm \\
0.000\end{array}$ \\
\hline
\end{tabular}

N.D: Not Determined 
Table A.2: Properties of sludge stored at $4^{\circ} \mathrm{C}$ and sampled weekly.

\begin{tabular}{|c|c|c|c|c|c|c|c|}
\hline $\begin{array}{c}\text { Property of the } \\
\text { sample }\end{array}$ & Initial & Week 1 & Week 2 & Week 3 & Week 4 & Week 6 & Week 7 \\
\hline pH & 7.75 & 7.82 & 7.74 & 7.73 & 7.67 & 7.66 & 7.75 \\
\hline $\begin{array}{c}\text { Specific } \\
\text { Conductance } \\
(\mu \mathrm{S} / \mathrm{cm}) \\
\end{array}$ & 3996 & 3992 & 3994 & 3999 & 4036 & 4037 & 4048 \\
\hline$\%$ Settled Sludge & N.D. & $59.0 \pm 0.0$ & $58.7 \pm 0.3$ & $57.4 \pm 0.7$ & $56.6 \pm 0.0$ & $54.2 \pm 0.6$ & $54.0 \pm 0.3$ \\
\hline $\begin{array}{c}\text { SRF x }\left(10^{7}\right) \\
\left(\sec ^{2} / \mathrm{gm}\right)\end{array}$ & N.D. & $\begin{array}{c}1.60 \pm \\
0.10\end{array}$ & $\begin{array}{c}1.37 \pm \\
0.06\end{array}$ & $\begin{array}{c}1.30 \pm \\
0.00\end{array}$ & $\begin{array}{c}1.13 \pm \\
0.06\end{array}$ & $\begin{array}{c}1.13 \pm \\
0.01\end{array}$ & $\begin{array}{c}1.09 \pm \\
0.07\end{array}$ \\
\hline $\begin{array}{l}\text { Viscosity } \\
\quad \text { (cP) }\end{array}$ & 9.9 & $9.8 \pm 0.1$ & $9.8 \pm 0.1$ & $9.7 \pm 0.1$ & $9.7 \pm 0.1$ & $9.4 \pm 0.1$ & $9.5 \pm 0.1$ \\
\hline $\begin{array}{c}\text { Mean Particle } \\
\text { Size }(\boldsymbol{\mu} \mathbf{m})\end{array}$ & 12.560 & $\begin{array}{c}9.561 \pm \\
0.060\end{array}$ & $\begin{array}{c}9.216 \pm \\
0.004\end{array}$ & $\begin{array}{c}9.148 \pm \\
0.093\end{array}$ & $\begin{array}{c}9.063 \pm \\
0.139\end{array}$ & $\begin{array}{c}8.781 \pm \\
0.239\end{array}$ & $\begin{array}{c}8.612 \pm \\
0.122\end{array}$ \\
\hline $\begin{array}{l}\text { Mode of Particle } \\
\text { Size }(\boldsymbol{\mu} \mathbf{~ m})\end{array}$ & 11.290 & $\begin{array}{c}7.775 \pm \\
0.000\end{array}$ & $\begin{array}{c}7.775 \pm \\
0.000\end{array}$ & $\begin{array}{c}7.775 \pm \\
0.000\end{array}$ & $\begin{array}{c}7.775 \pm \\
0.000\end{array}$ & $\begin{array}{c}8.029 \pm \\
0.439\end{array}$ & $\begin{array}{c}7.314 \pm \\
0.400\end{array}$ \\
\hline
\end{tabular}

N.D. - Not Determined 
Table A.3: Properties of sludge stored at $20^{\circ} \mathrm{C}$ and sampled at a longer interval of time.

\begin{tabular}{|c|c|c|c|c|}
\hline $\begin{array}{l}\text { Property of the } \\
\text { sample }\end{array}$ & Initial & Week 4 & Week 6 & Week 8 \\
\hline pH & 7.76 & 7.68 & 7.50 & 7.30 \\
\hline $\begin{array}{c}\text { Specific } \\
\text { Conductance } \\
(\mu \mathrm{S} / \mathbf{c m})\end{array}$ & 3996 & 4032 & 4034 & 4025 \\
\hline$\%$ Settled Sludge & N.D. & $62.7 \pm 0.0$ & $59.9 \pm 0.2$ & $60.1 \pm 0.2$ \\
\hline $\begin{array}{l}\operatorname{SRF} \times\left(10^{7}\right) \\
\left(\sec ^{2} / g m\right)\end{array}$ & N.D. & $0.70 \pm 0.01$ & $0.67 \pm 0.01$ & $0.71 \pm 0.00$ \\
\hline $\begin{array}{l}\text { Viscosity } \\
\text { (cP) }\end{array}$ & 9.5 & $9.9 \pm 0.0$ & $9.7 \pm 0.1$ & $9.9 \pm 0.1$ \\
\hline $\begin{array}{c}\text { Mean Particle } \\
\text { Size }(\mu \mathrm{m})\end{array}$ & 13.980 & $12.960 \pm 0.115$ & $12.480 \pm 0.017$ & $12.190 \pm 0.156$ \\
\hline $\begin{array}{l}\text { Mode of Particle } \\
\text { Size }(\mu \mathrm{m})\end{array}$ & 11.290 & $10.957 \pm 0.577$ & $10.290 \pm 0.000$ & $10.290 \pm 0.000$ \\
\hline
\end{tabular}

N.D. - Not Determined 
Table A.4: Properties of sludge stored at $4^{\circ} \mathrm{C}$ and sampled at a longer interval of time.

\begin{tabular}{|c|c|c|c|c|}
\hline $\begin{array}{c}\text { Property of the } \\
\text { sample }\end{array}$ & Initial & Week 4 & Week 6 & Week 8 \\
\hline pH & 7.77 & 7.79 & 8.11 & 7.78 \\
\hline $\begin{array}{c}\text { Specific } \\
\text { Conductance } \\
(\boldsymbol{\mu} \text { S/cm) }\end{array}$ & 4006 & 4030 & 4018 & 4014 \\
\hline $\begin{array}{c}\text { \%ottled Sludge } \\
\text { Sed }\end{array}$ & N.D. & $63.9 \pm 0.0$ & $60.2 \pm 0.0$ & $63.5 \pm 0.7$ \\
\hline $\begin{array}{c}\text { SRF (10 }) \\
(\text { sec } / \text { gm) }\end{array}$ & N.D. & $1.17 \pm 0.06$ & $1.08 \pm 0.11$ & $0.95 \pm 0.05$ \\
\hline $\begin{array}{c}\text { Viscosity } \\
(\mathbf{c P})\end{array}$ & 9.4 & $9.9 \pm 0.0$ & $9.8 \pm 0.0$ & $10.0 \pm 0.1$ \\
\hline $\begin{array}{c}\text { Mean Particle Size } \\
(\boldsymbol{\mu} \text { m) }\end{array}$ & 14.100 & $13.813 \pm 1.410$ & $11.423 \pm 0.474$ & $10.863 \pm 0.527$ \\
\hline $\begin{array}{c}\text { Mode of Particle } \\
\text { Size ( } \boldsymbol{\mu} \text { m) }\end{array}$ & 10.290 & $10.290 \pm 0.000$ & $10.290 \pm 0.000$ & $9.121 \pm 1.013$ \\
\hline
\end{tabular}

N.D. - Not Determined 


\section{APPENDIX B: DATA FROM DEWATERING EXPERIMENTS}

Table B.1: Properties of four sludge samples collected before primary settling at the treatment site.

\begin{tabular}{|c|c|c|c|c|}
\hline Property & Sample 1 & Sample 2 & Sample 3 & Sample 4 \\
\hline pH & 9.19 & 9.34 & 8.67 & 9.15 \\
\hline $\begin{array}{l}\text { Specific Conductance } \\
(\boldsymbol{( \mu \mathrm { S } / \mathrm { cm } )}\end{array}$ & 3799 & 3889 & 3488 & 3625 \\
\hline Viscosity ( cP ) & $8.8 \pm 0.1$ & $8.8 \pm 0.1$ & $8.6 \pm 0.1$ & $8.7 \pm 0.1$ \\
\hline$\%$ Settled Sludge & $21.8 \pm 1.2$ & $22.1 \pm 0.3$ & $21.5 \pm 0.9$ & $21.8 \pm 1.3$ \\
\hline $\begin{array}{c}\text { \% Total Solids (g/g) } \\
\text { ( Initial ) }\end{array}$ & 0.18 & 0.17 & 0.18 & 0.24 \\
\hline $\begin{array}{l}\text { S.R.F } \times\left(10^{7}\right) \\
\left(\mathrm{sec}^{2} / \mathrm{gm}\right)\end{array}$ & $2.92 \pm 0.61$ & $1.46 \pm 0.13$ & $1.26 \pm 0.11$ & $1.33 \pm 0.10$ \\
\hline Pumping Rate ( gpm ) & 108 & 90 & 98 & 90 \\
\hline
\end{tabular}


Table B.2: Volume of water removed and Efficiency of the three dewatering methods for sludge samples collected before primary settling at the treatment site.

\begin{tabular}{|c|c|c|c|c|c|c|c|c|c|}
\hline \multicolumn{2}{|l|}{ Dewatering Method } & Sample 1 & $\mathbf{E}$ & Sample 2 & $\mathbf{E}$ & Sample 3 & $\mathbf{E}$ & Sample 4 & $\mathbf{E}$ \\
\hline \multicolumn{2}{|l|}{ Vacuum Filtration } & 173 & 96 & 174 & 97 & 175 & 97 & 175 & 97 \\
\hline \multicolumn{2}{|l|}{ Pressure Filtration } & $\mathrm{F}$ & & $\mathrm{F}$ & & $\mathrm{F}$ & & $\mathrm{F}$ & \\
\hline \multicolumn{10}{|c|}{ Coagulants and Flocculants } \\
\hline \multirow{5}{*}{ Calloway 4910} & $0 \mathrm{ppm}$ & 390 & 78 & 392 & 78 & 400 & 80 & 390 & 78 \\
\hline & 20 ppm & 392 & 78 & 400 & 80 & 395 & 79 & 395 & 79 \\
\hline & $40 \mathrm{ppm}$ & 390 & 78 & 399 & 80 & 395 & 79 & 397 & 79 \\
\hline & $60 \mathrm{ppm}$ & 400 & 80 & 405 & 81 & 425 & 85 & 405 & 81 \\
\hline & $120 \mathrm{ppm}$ & 450 & 90 & 460 & 92 & 465 & 93 & 455 & 91 \\
\hline \multirow{5}{*}{ Alco Clear ACP } & $0 \mathrm{ppm}$ & 385 & 77 & 395 & 79 & 398 & 80 & 396 & 79 \\
\hline & $20 \mathrm{ppm}$ & 378 & 76 & 375 & 75 & 390 & 78 & 380 & 76 \\
\hline & 40 ppm & 370 & 74 & 380 & 76 & 370 & 74 & 380 & 76 \\
\hline & $60 \mathrm{ppm}$ & 370 & 74 & 380 & 76 & 370 & 74 & 380 & 76 \\
\hline & $120 \mathrm{ppm}$ & 355 & 71 & 370 & 74 & 365 & 73 & 395 & 79 \\
\hline \multirow{5}{*}{ Acco-Phos 1250} & $0 \mathrm{ppm}$ & 395 & 79 & 400 & 80 & 410 & 82 & 398 & 80 \\
\hline & $20 \mathrm{ppm}$ & 395 & 79 & 400 & 80 & 415 & 83 & 398 & 80 \\
\hline & $40 \mathrm{ppm}$ & 393 & 79 & 405 & 81 & 390 & 78 & 400 & 80 \\
\hline & $60 \mathrm{ppm}$ & 410 & 82 & 410 & 82 & 430 & 86 & 435 & 87 \\
\hline & $120 \mathrm{ppm}$ & 465 & 93 & 465 & 93 & 455 & 91 & 460 & 92 \\
\hline
\end{tabular}

F: Filter paper was unable to capture any solids for pressure filtration.

E: Efficiency: Ratio of filtrate volume to the initial volume of the sludge.

: The sludge was floating on water instead of settling at the bottom of the container. 
Table B.3: \% Total Solids and Concentration Factor of the three dewatering methods for sludge samples collected before primary settling at the treatment site.

\begin{tabular}{|c|c|c|c|c|c|c|c|c|c|}
\hline \multicolumn{2}{|c|}{ Dewatering Method } & Sample 1 & C & Sample 2 & C & Sample 3 & $\mathbf{C}$ & Sample 4 & $\mathrm{C}$ \\
\hline \multicolumn{2}{|c|}{ Vacuum Filtration } & $9.41 \pm 0.65$ & 52.3 & $9.66 \pm 1.32$ & 56.8 & $8.32 \pm 1.88$ & 46.2 & $9.08 \pm 0.57$ & 37.8 \\
\hline \multicolumn{2}{|c|}{ Pressure Filtration } & $\mathrm{F}$ & & $\mathrm{F}$ & & $\mathrm{F}$ & & $\mathrm{F}$ & \\
\hline \multicolumn{10}{|c|}{ Coagulants and Flocculants } \\
\hline \multirow{5}{*}{ Calloway 4910} & 0 ppm & 0.54 & 3.0 & 0.47 & 2.8 & 0.62 & 3.4 & 0.55 & 2.3 \\
\hline & $20 \mathrm{ppm}$ & 0.53 & 2.9 & 0.39 & 2.3 & 0.54 & 3.0 & 0.55 & 2.3 \\
\hline & 40 ppm & 0.50 & 2.8 & 0.41 & 2.4 & 0.52 & 2.9 & 0.49 & 2.0 \\
\hline & 60 ppm & 0.60 & 3.3 & 0.41 & 2.4 & 0.81 & 4.5 & 0.47 & 2.0 \\
\hline & $120 \mathrm{ppm}$ & 1.81 & 10.1 & 2.09 & 12.3 & 2.18 & 12.1 & 2.00 & 8.3 \\
\hline \multirow{5}{*}{ Alco Clear ACP } & 0 ppm & 0.59 & 3.3 & 0.39 & 2.3 & 0.69 & 3.8 & 0.60 & 2.5 \\
\hline & 20 ppm & 0.53 & 2.9 & 0.45 & 2.6 & 0.51 & 2.8 & 0.47 & 2.0 \\
\hline & 40 ppm & 0.56 & 3.1 & 0.52 & 3.1 & 0.41 & 2.3 & 0.44 & 1.8 \\
\hline & 60 ppm & 0.44 & 2.4 & 0.50 & 2.9 & 0.39 & 2.2 & 0.45 & 1.9 \\
\hline & $120 \mathrm{ppm}$ & 0.43 & 2.4 & 0.49 & 2.9 & 0.40 & 2.2 & 0.56 & 2.3 \\
\hline \multirow{5}{*}{ Acco-Phos 1250} & $0 \mathrm{ppm}$ & 0.55 & 3.1 & 0.50 & 2.9 & 0.64 & 3.6 & 0.62 & 2.6 \\
\hline & 20 ppm & 0.49 & 2.7 & 0.62 & 3.6 & 0.49 & 2.7 & 0.60 & 2.5 \\
\hline & 40 ppm & 0.39 & 2.2 & 0.58 & 3.4 & 0.50 & 2.8 & 0.35 & 1.5 \\
\hline & 60 ppm & 0.48 & 2.7 & 0.60 & 3.5 & 1.07 & 5.9 & 0.72 & 3.0 \\
\hline & $120 \mathrm{ppm}$ & 2.50 & 13.9 & 2.77 & 16.3 & 2.22 & 12.3 & 2.41 & 10.0 \\
\hline
\end{tabular}

F: Filter paper was unable to capture any solids for pressure filtration.

C: Concentration Factor: Ratio of final total solids to initial total solids of the sludge. 
Table B.4: Properties of four sludge samples collected after primary settling at the treatment site.

\begin{tabular}{|c|c|c|c|c|}
\hline Property & Sample 1 & Sample 2 & Sample 3 & Sample 4 \\
\hline pH & 9.04 & 9.11 & 8.96 & 9.23 \\
\hline $\begin{array}{l}\text { Specific Conductance } \\
\qquad(\mu \mathrm{S} / \mathrm{cm})\end{array}$ & 3234 & 3164 & 3654 & 3966 \\
\hline Viscosity ( cP ) & $10.5 \pm 0.3$ & $11.3 \pm 0.1$ & $11.7 \pm 0.1$ & $13.1 \pm 0.2$ \\
\hline$\%$ Settled Sludge & $62.8 \pm 0.1$ & $79.3 \pm 0.3$ & $75.5 \pm 0.2$ & $87.8 \pm 0.2$ \\
\hline $\begin{array}{c}\text { \% Total Solids (g/g) } \\
\text { ( Initial ) }\end{array}$ & 0.47 & $0.71 \pm 0.00$ & $1.03 \pm 0.01$ & $1.13 \pm 0.02$ \\
\hline $\begin{array}{l}\text { S.R.F x (10 }) \\
\left(\mathrm{sec}^{2} / \mathrm{gm}\right)\end{array}$ & $3.80 \pm 0.08$ & $4.05 \pm 0.09$ & $4.28 \pm 0.41$ & $5.60 \pm 0.16$ \\
\hline
\end{tabular}


Table B.5: Filtrate Volume and Efficiency of the three dewatering methods for sludge collected after primary settling at the treatment site.

\begin{tabular}{|c|c|c|c|c|c|c|c|c|c|}
\hline \multicolumn{2}{|l|}{ Dewatering Method } & Sample 1 & $\mathbf{E}$ & Sample 2 & $\mathbf{E}$ & Sample 3 & $\mathbf{E}$ & Sample 4 & $\mathbf{E}$ \\
\hline \multicolumn{2}{|l|}{ Vacuum Filtration } & 171 & 95 & 166 & 92 & 163 & 91 & 155 & 86 \\
\hline \multicolumn{2}{|l|}{ Pressure Filtration } & 171 & 95 & 168 & 93 & 164 & 91 & 160 & 89 \\
\hline \multicolumn{10}{|c|}{ Coagulants and Flocculants } \\
\hline \multirow{5}{*}{ Calloway 4910} & 0 ppm & 183 & 37 & 98 & 20 & 120 & 24 & 50 & 10 \\
\hline & $20 \mathrm{ppm}$ & 183 & 37 & 96 & 19 & 120 & 24 & 50 & 10 \\
\hline & $40 \mathrm{ppm}$ & 185 & 37 & 96 & 19 & 116 & 23 & 48 & 10 \\
\hline & $60 \mathrm{ppm}$ & 188 & 38 & 94 & 19 & 116 & 23 & 42 & 8 \\
\hline & $120 \mathrm{ppm}$ & 223 & 45 & 122 & 24 & 145 & 29 & 52 & 10 \\
\hline \multirow{5}{*}{ Alco Clear ACP } & 0 ppm & 187 & 37 & 102 & 20 & 122 & 24 & 54 & 11 \\
\hline & $20 \mathrm{ppm}$ & 185 & 37 & 100 & 20 & 122 & 24 & 50 & 10 \\
\hline & $40 \mathrm{ppm}$ & 180 & 36 & 96 & 19 & 114 & 23 & 46 & 9 \\
\hline & $60 \mathrm{ppm}$ & 182 & 36 & 96 & 19 & 114 & 23 & 42 & 8 \\
\hline & $120 \mathrm{ppm}$ & 178 & 36 & 96 & 19 & 114 & 23 & 26 & 5 \\
\hline \multirow{5}{*}{ Acco-Phos 1250} & 0 ppm & 185 & 37 & 98 & 20 & 121 & 24 & 54 & 11 \\
\hline & $20 \mathrm{ppm}$ & 188 & 38 & 98 & 20 & 122 & 24 & 46 & 9 \\
\hline & 40 ppm & 185 & 37 & 96 & 19 & 120 & 24 & 48 & 10 \\
\hline & $60 \mathrm{ppm}$ & 190 & 38 & 91 & 18 & 114 & 23 & 40 & 8 \\
\hline & $120 \mathrm{ppm}$ & 190 & 38 & 87 & 17 & 106 & 21 & 24 & 5 \\
\hline
\end{tabular}

E: Efficiency: Ratio of filtrate volume to the initial volume of the sludge. 
Table B.6: \% Total Solids and Concentration Factor of the three dewatering methods for sludge collected after primary settling at the treatment site.

\begin{tabular}{|c|c|c|c|c|c|c|c|c|c|}
\hline \multicolumn{2}{|c|}{ Dewatering Method } & Sample 1 & $\mathbf{C}$ & Sample 2 & $\mathbf{C}$ & Sample 3 & $\mathbf{C}$ & Sample 4 & $\mathbf{C}$ \\
\hline \multicolumn{2}{|c|}{ Vacuum Filtration } & $6.08 \pm 0.07$ & 12.9 & $6.51 \pm 0.07$ & 9.2 & $7.65 \pm 0.40$ & 7.4 & $6.63 \pm 0.09$ & 5.9 \\
\hline \multicolumn{2}{|c|}{ Pressure Filtration } & $10.21 \pm 1.00$ & 21.7 & $9.54 \pm 0.50$ & 13.4 & $10.01 \pm 0.58$ & 9.7 & $9.74 \pm 0.06$ & 8.6 \\
\hline \multicolumn{10}{|c|}{ Coagulants and Flocculants } \\
\hline \multirow{5}{*}{ Calloway 4910} & $0 \mathrm{ppm}$ & 0.82 & 1.7 & 0.88 & 1.2 & 1.55 & 1.5 & 1.25 & 1.1 \\
\hline & 20 ppm & 0.94 & 2.0 & 0.90 & 1.3 & 1.38 & 1.3 & 1.26 & 1.1 \\
\hline & 40 ppm & 0.97 & 2.1 & 0.91 & 1.3 & 1.42 & 1.4 & 1.23 & 1.1 \\
\hline & 60 ppm & 0.90 & 1.9 & 0.92 & 1.3 & 1.37 & 1.3 & 1.30 & 1.2 \\
\hline & 120 ppm & 0.90 & 1.9 & 0.89 & 1.3 & 1.37 & 1.3 & 1.19 & 1.1 \\
\hline \multirow{5}{*}{ Alco Clear ACP } & $0 \mathrm{ppm}$ & 0.88 & 1.9 & 0.93 & 1.3 & 1.40 & 1.4 & 1.25 & 1.1 \\
\hline & 20 ppm & 0.84 & 1.8 & 0.94 & 1.3 & 1.38 & 1.3 & 1.21 & 1.1 \\
\hline & 40 ppm & 0.86 & 1.8 & 0.93 & 1.3 & 1.34 & 1.3 & 1.25 & 1.1 \\
\hline & 60 ppm & 0.84 & 1.8 & 0.91 & 1.3 & 1.32 & 1.3 & 1.21 & 1.1 \\
\hline & 120 ppm & 0.91 & 1.9 & 0.90 & 1.3 & 1.33 & 1.3 & 1.19 & 1.1 \\
\hline \multirow{5}{*}{ Acco-Phos 1250} & $0 \mathrm{ppm}$ & 0.87 & 1.9 & 0.89 & 1.3 & 1.37 & 1.3 & 1.26 & 1.1 \\
\hline & 20 ppm & 0.72 & 1.5 & 0.93 & 1.3 & 1.42 & 1.4 & 1.26 & 1.1 \\
\hline & 40 ppm & 0.86 & 1.8 & 0.91 & 1.3 & 1.41 & 1.4 & 1.29 & 1.1 \\
\hline & 60 ppm & 0.89 & 1.9 & 0.90 & 1.3 & 1.37 & 1.3 & 1.26 & 1.1 \\
\hline & $120 \mathrm{ppm}$ & 0.92 & 2.0 & 0.89 & 1.3 & 1.32 & 1.3 & 1.23 & 1.1 \\
\hline
\end{tabular}

C: Concentration Factor: Ratio of final total solids to initial total solids of the sludge. 


\section{APPENDIX C: DATA FROM KRUSKAL-WALLIS TEST IN THE AGING EXPERIMENT}

Table C.1: Differences in Percent Settled Sludge between the weeks for the sludge stored at $20^{\circ} \mathrm{C}$ and sampled weekly.

\begin{tabular}{cccccc}
\hline $\begin{array}{c}\text { Comparision of } \\
\text { Weeks }\end{array}$ & $\begin{array}{c}\text { Rank Sum } \\
\text { Diff. }\end{array}$ & $\begin{array}{c}\text { Standard Error } \\
\text { (SE) }\end{array}$ & $\mathbf{q}$ & $\mathbf{q}_{\mathbf{c}}$ & D/ND \\
\hline W1 vs W4 & 39.51 & 9.246621 & 4.272912 & 4.030 & $\mathrm{D}$ \\
W1 vs W2 & 30.99 & 9.246621 & 3.351495 & 4.030 & ND \\
W1 vs W6 & 29.49 & 9.246621 & 3.189273 & 4.030 & ND \\
W1 vs W7 & 26.01 & 9.246621 & 2.812919 & 4.030 & ND \\
W1 vs W3 & 9 & 9.246621 & 0.973329 & 4.030 & ND \\
W3 vs W4 & 30.51 & 9.246621 & 3.299584 & 4.030 & ND \\
W3 vs W2 & 21.99 & 9.246621 & 2.378166 & 4.030 & ND \\
W3 vs W6 & 20.49 & 9.246621 & 2.215945 & 4.030 & ND \\
W3 vs W7 & 17.01 & 9.246621 & 1.839591 & 4.030 & ND \\
W7 vs W4 & 13.5 & 9.246621 & 1.459993 & 4.030 & ND \\
W7 vs W2 & 4.98 & 9.246621 & 0.538575 & 4.030 & ND \\
W7 vs W6 & 3.48 & 9.246621 & 0.376354 & 4.030 & ND \\
W6 vs W4 & 10.02 & 9.246621 & 1.083639 & 4.030 & ND \\
W6 vs W2 & 1.5 & 9.246621 & 0.162221 & 4.030 & ND \\
W2 vs W4 & 8.52 & 9.246621 & 0.921418 & 4.030 & ND \\
\hline
\end{tabular}

W-weeks, q $\mathrm{q}_{\mathrm{c}}$-critical q, D/ND-Difference/No Difference

Table C.2: Differences in Mean Particle Size between the weeks for the sludge stored at $20^{\circ} \mathrm{C}$ and sampled weekly.

\begin{tabular}{cccccc}
\hline $\begin{array}{c}\text { Comparision } \\
\text { of Weeks }\end{array}$ & $\begin{array}{c}\text { Rank } \\
\text { Sum Diff. }\end{array}$ & $\begin{array}{c}\text { Standard Error } \\
\text { (SE) }\end{array}$ & $\mathbf{q}$ & $\mathbf{q}_{\mathbf{c}}$ & D/ND \\
\hline W1 vs W4 & 42 & 9.246621 & 4.5422 & 4.030 & $\mathrm{D}$ \\
W1 vs W6 & 32.01 & 9.246621 & 3.461805 & 4.030 & ND \\
W1 vs W3 & 24.99 & 9.246621 & 2.702609 & 4.030 & ND \\
W1 vs W7 & 24 & 9.246621 & 2.595543 & 4.030 & ND \\
W1 vs W2 & 12 & 9.246621 & 1.297771 & 4.030 & ND \\
W2 vs W4 & 30 & 9.246621 & 3.244428 & 4.030 & ND \\
W2 vs W6 & 20.01 & 9.246621 & 2.164034 & 4.030 & ND \\
W2 vs W3 & 12.99 & 9.246621 & 1.404838 & 4.030 & ND \\
W2 vs W7 & 12 & 9.246621 & 1.297771 & 4.030 & ND \\
W7 vs W4 & 18 & 9.246621 & 1.946657 & 4.030 & ND \\
W7 vs W6 & 8.01 & 9.246621 & 0.866262 & 4.030 & ND \\
W7 vs W3 & 0.99 & 9.246621 & 0.107066 & 4.030 & ND \\
W3 vs W4 & 17.01 & 9.246621 & 1.839591 & 4.030 & ND \\
W3 vs W6 & 7.02 & 9.246621 & 0.759196 & 4.030 & ND \\
W6 vs W4 & 9.99 & 9.246621 & 1.080395 & 4.030 & ND \\
\hline
\end{tabular}

W-weeks, qc-critical q, D/ND-Difference/No Difference 
Table C.3: Differences in Mode of Particle Size between the weeks for the sludge stored at $20^{\circ} \mathrm{C}$ and sampled weekly.

\begin{tabular}{cccccc}
\hline $\begin{array}{c}\text { Comparision } \\
\text { of Weeks }\end{array}$ & $\begin{array}{c}\text { Rank } \\
\text { Sum Diff. }\end{array}$ & $\begin{array}{c}\text { Standard Error } \\
\text { (SE) }\end{array}$ & $\mathbf{q}$ & $\mathbf{q}_{\mathbf{c}}$ & D/ND \\
\hline W1 vs W 4 & 27 & 9.24662 & 2.919986 & 4.030 & ND \\
W1 vs W2 & 27 & 9.24662 & 2.919986 & 4.030 & ND \\
W1 vs W6 & 27 & 9.24662 & 2.919986 & 4.030 & ND \\
W1 vs W7 & 27 & 9.24662 & 2.919986 & 4.030 & ND \\
W1 vs W3 & 27 & 9.24662 & 2.919986 & 4.030 & ND \\
W3 vs W4 & 0 & 9.24662 & 0 & 4.030 & ND \\
W3 vs W2 & 0 & 9.24662 & 0 & 4.030 & ND \\
W3 vs W6 & 0 & 9.24662 & 0 & 4.030 & ND \\
W3 vs W7 & 0 & 9.24662 & 0 & 4.030 & ND \\
W7 vs W4 & 0 & 9.24662 & 0 & 4.030 & ND \\
W7 vs W2 & 0 & 9.24662 & 0 & 4.030 & ND \\
W7 vs W6 & 0 & 9.24662 & 0 & 4.030 & ND \\
W6 vs W4 & 0 & 9.24662 & 0 & 4.030 & ND \\
W6 vs W2 & 0 & 9.24662 & 0 & 4.030 & ND \\
W2 vs W4 & 0 & 9.24662 & 0 & 4.030 & ND \\
\hline
\end{tabular}

W-weeks, qc-critical q, D/ND-Difference/No Difference

Table C.4: Differences in Percent Settled Sludge between the weeks for the sludge stored at $4^{\circ} \mathrm{C}$ and sampled weekly.

\begin{tabular}{cccccc}
\hline $\begin{array}{c}\text { Comparision } \\
\text { of Weeks }\end{array}$ & $\begin{array}{c}\text { Rank Sum } \\
\text { Diff. }\end{array}$ & $\begin{array}{c}\text { Standard Error } \\
\text { (SE) }\end{array}$ & $\mathbf{q}$ & $\mathbf{q}_{\mathbf{c}}$ & D/ND \\
\hline W1 vs W7 & 39.51 & 9.246621 & 4.272912 & 4.030 & $\mathrm{D}$ \\
W1 vs W6 & 38.49 & 9.246621 & 4.162602 & 4.030 & $\mathrm{D}$ \\
W1 vs W4 & 24.00 & 9.246621 & 2.595543 & 4.030 & ND \\
W1 vs W3 & 18.00 & 9.246621 & 1.946657 & 4.030 & ND \\
W1 vs W2 & 6.00 & 9.246621 & 0.648886 & 4.030 & ND \\
W2 vs W7 & 33.51 & 9.246621 & 3.624027 & 4.030 & ND \\
W2 vs W6 & 32.49 & 9.246621 & 3.513716 & 4.030 & ND \\
W2 vs W4 & 18.00 & 9.246621 & 1.946657 & 4.030 & ND \\
W2 vs W3 & 12.00 & 9.246621 & 1.297771 & 4.030 & ND \\
W3 vs W7 & 21.51 & 9.246621 & 2.326255 & 4.030 & ND \\
W3 vs W6 & 20.49 & 9.246621 & 2.215945 & 4.030 & ND \\
W3 vs W4 & 6.00 & 9.246621 & 0.648886 & 4.030 & ND \\
W4 vs W7 & 15.51 & 9.246621 & 1.677369 & 4.030 & ND \\
W4 vs W6 & 14.49 & 9.246621 & 1.567059 & 4.030 & ND \\
W6 vs W7 & 1.02 & 9.246621 & 0.110311 & 4.030 & ND \\
\hline
\end{tabular}

W-weeks, qc-critical q, D/ND-Difference/No Difference 
Table C.5: Differences in Mean Particle Size between the weeks for the sludge stored at $4^{\circ} \mathrm{C}$ and sampled weekly.

\begin{tabular}{cccccc}
\hline $\begin{array}{c}\text { Comparision } \\
\text { of Weeks }\end{array}$ & $\begin{array}{c}\text { Rank Sum } \\
\text { Diff. }\end{array}$ & $\begin{array}{c}\text { Standard } \\
\text { Error (SE) }\end{array}$ & $\mathbf{q}$ & $\mathbf{q}_{\mathbf{c}}$ & D/ND \\
\hline W1 vs W7 & 42.99 & 9.246621 & 4.649266 & 4.030 & $\mathrm{D}$ \\
W1 vs W6 & 36.99 & 9.246621 & 4.00038 & 4.030 & ND \\
W1 vs W4 & 23.01 & 9.246621 & 2.488477 & 4.030 & ND \\
W1 vs W3 & 17.01 & 9.246621 & 1.839591 & 4.030 & ND \\
W1 vs W2 & 15 & 9.246621 & 1.622214 & 4.030 & ND \\
W2 vs W7 & 27.99 & 9.246621 & 3.027052 & 4.030 & ND \\
W2 vs W6 & 21.99 & 9.246621 & 2.378166 & 4.030 & ND \\
W2 vs W4 & 8.01 & 9.246621 & 0.866262 & 4.030 & ND \\
W2 vs W3 & 2.01 & 9.246621 & 0.217377 & 4.030 & ND \\
W3 vs W6 & 25.98 & 9.246621 & 2.809675 & 4.030 & ND \\
W3 vs W6 & 19.98 & 9.246621 & 2.160789 & 4.030 & ND \\
W3 vs W4 & 6 & 9.246621 & 0.648886 & 4.030 & ND \\
W4 vs W7 & 19.98 & 9.246621 & 2.160789 & 4.030 & ND \\
W4 vs W6 & 13.98 & 9.246621 & 1.511904 & 4.030 & ND \\
W6 vs W7 & 6 & 9.246621 & 0.648886 & 4.030 & ND \\
\hline
\end{tabular}

W-weeks, qc-critical q, D/ND-Difference/No Difference

Table C.6: Differences in Mean Particle Size between the weeks for the sludge stored at $4^{\circ} \mathrm{C}$ and sampled weekly.

\begin{tabular}{cccccc}
\hline $\begin{array}{c}\text { Comparision } \\
\text { of Weeks }\end{array}$ & $\begin{array}{c}\text { Rank Sum } \\
\text { Diff. }\end{array}$ & $\begin{array}{c}\text { Standard Error } \\
\text { (SE) }\end{array}$ & $\mathbf{q}$ & $\mathbf{q}_{\mathbf{c}}$ & D/ND \\
\hline W6 vs W7 & 25.02 & 9.246621 & 2.705853 & 4.030 & ND \\
W6 vs W4 & 8.01 & 9.246621 & 0.866262 & 4.030 & ND \\
W6 vs W3 & 8.01 & 9.246621 & 0.866262 & 4.030 & ND \\
W6 vs W2 & 8.01 & 9.246621 & 0.866262 & 4.030 & ND \\
W6 vs W1 & 8.01 & 9.246621 & 0.866262 & 4.030 & ND \\
W1 vs W7 & 17.01 & 9.246621 & 1.839591 & 4.030 & ND \\
W1 vs W4 & 0 & 9.246621 & 0 & 4.030 & ND \\
W1 vs W3 & 0 & 9.246621 & 0 & 4.030 & ND \\
W1 vs W2 & 0 & 9.246621 & 0 & 4.030 & ND \\
W2 vs W7 & 17.01 & 9.246621 & 1.839591 & 4.030 & ND \\
W2 vs W4 & 0 & 9.246621 & 0 & 4.030 & ND \\
W2 vs W3 & 0 & 9.246621 & 0 & 4.030 & ND \\
W3 vs W7 & 17.01 & 9.246621 & 1.839591 & 4.030 & ND \\
W3 vs W4 & 0 & 9.246621 & 0 & 4.030 & ND \\
W4 vs W7 & 17.01 & 9.246621 & 1.839591 & 4.030 & ND \\
\hline
\end{tabular}

W-weeks, qc-critical q, D/ND-Difference/No Difference 


\section{APPENDIX D: FLOCCULANT ADDITION PROCEDURE}

Procedure developed by WVU-CEE researchers: Mr. Xinchao Wei and Dr. Karen Buzby

1. Bring the sludge to room temperature.

2. Take a $600-\mathrm{ml}$ beaker and fill it with $500 \mathrm{ml}$ sludge.

3. Using a Phipps and Bird stirrer, mix the sludge at $100 \mathrm{rpm}$ for 2 minutes.

4. After 2 minutes, add sufficient $0.1 \%$ flocculant solution to the beaker to obtain the required concentration. The amount of flocculant added will vary with the required concentration.

5. Mix the sludge for 2 minutes at $100 \mathrm{rpm}$.

6. After 2 minutes, remove the beaker and allow it to settle.

7. Record the initial height of the sludge and the time.

8. After 24 hours, record the total height of sludge in the beaker.

Sample procedure for the preparation of $0.1 \%$ flocculant solution is as follows:

1. Add $199 \mathrm{ml}$ distilled water to a clean $600 \mathrm{ml}$ beaker.

2. Using a syringe, inject $1 \mathrm{ml}$ of the polymer into the beaker.

3. Insert the Braun 200 watts Immersion Blender into water and mix for 10 seconds to obtain a $0.5 \%$ flocculant solution.

4. Take $80 \mathrm{ml}$ distilled water in a clean beaker and add $20 \mathrm{ml}$ of $0.5 \%$ flocculant solution to obtain $0.1 \%$ flocculant solution.

5. Shake vigorously for at least 1 minute and allow the dilute polymer to age for at least 30 minutes. 